NUREG/CR-6474

BNL-NUREG-52504

\title{
Preliminary Phenomena Identification and Ranking Tables (PIRT) for SBWR Start-Up Stability
}

Manuscript Completed: February 1997

Date Published: March 1997

Prepared by

U. S. Rohatgi, H. S. Cheng, H. J. Khan, W. Wulff

Brookhaven National Laboratory

Upton, NY 11973

\section{DISCLAIMER}

This report was prepared as an account of work sponsored by an agency of the United States Government. Neither the United States Government nor any agency thereof, nor any of their bility for the accs any warranty, express or implied, or assumes any legal liability or responsiprose completeness, or usefulness of any information, apparatus, product, or process disclosed, or represents that its use would not infringe privately owned rights. Refer-

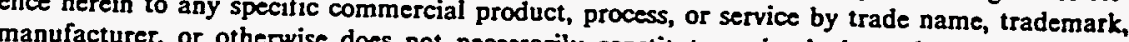
manufacturer, or otherwise does not necessarily constitute or imply its endorsement, recommendation, or favoring by the United States Government or any agency thereof. The views and opinions of authors expressed herein do not necessarily state or reflect those of the United States Government or any agency thereof.

\section{Prepared for}

Division of Systems Technology

Office of Nuclear Regulatory Research

U.S. Nuclear Regulatory Commission

Washington, DC 20555-0001

NRC Job Code L2187
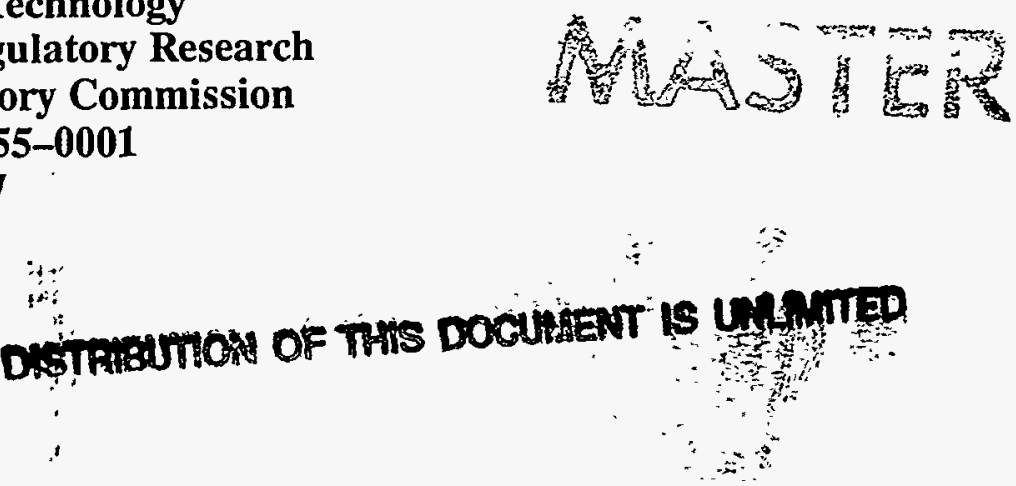


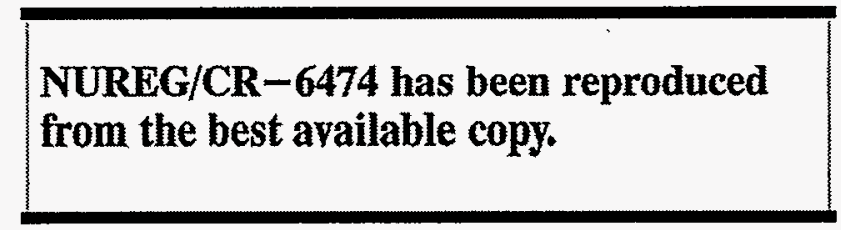




\section{DISCLAIMER}

Portions of this document may be illegible in electronic image products. Images are produced from the best available original document. 


\begin{abstract}
Phenomena Identification and Ranking Tables (PIRT) have been developed for start-up transient for SBWR. The information used for PIRT came from RAMONA-4B and TRACG analyses of the transient and from related small scale tests. The transient was divided into four distinct phases, namely, Subcooled Core Heat-up, Subcooled Chimney, Saturated Chimney, and Power Ascension. The assessment criterion selected was Minimum Critical Power Ratio. The SBWR system was divided into ten components. A total of 33 distinct phenomena among the components were identified. The Phase I has 28 ranked phenomena with 17 low , 6 medium and 5 high ranking. The Phase II has 39 ranked phenomena with 18 low, 13 medium and 8 high ranking. The Phase III has 47 ranked phenomena with 22 low, 10 medium and 15 high ranking. The Phase IV has 46 ranked phenomena with 16 low, 12 medium and 18 high ranking.
\end{abstract}

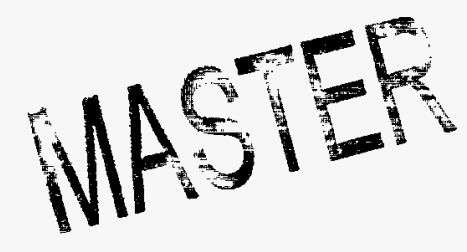





\section{TABLE OF CONTENTS}

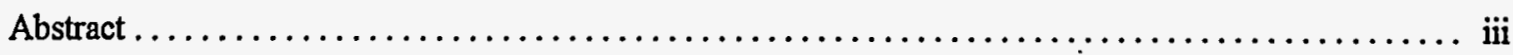

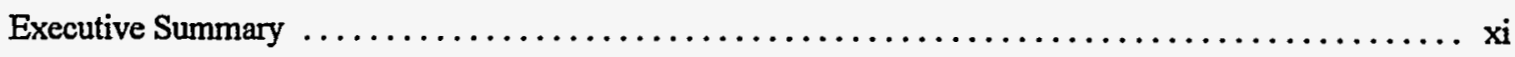

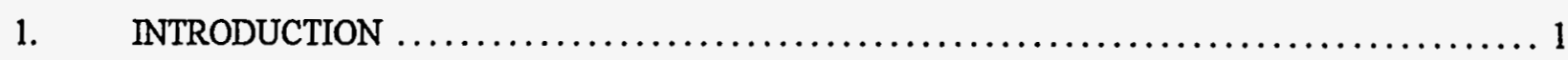

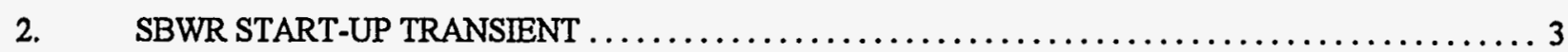

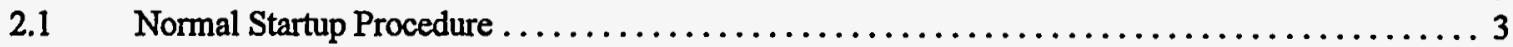

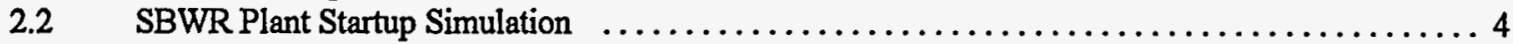

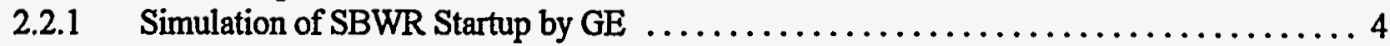

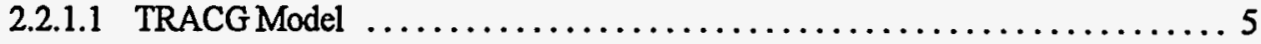

2.2.1.2 Analysis of Results from TRACG $\ldots \ldots \ldots \ldots \ldots \ldots \ldots \ldots \ldots \ldots \ldots$

2.2.2 Simulation of SBWR Startup by BNL using RAMONA-4B Code $\ldots \ldots \ldots \ldots \ldots \ldots 5$

2.2.2.1 RAMONA-4B Model .................................... 9

2.2.2.2 Initial and Boundary Conditions for Startup $\ldots \ldots \ldots \ldots \ldots \ldots \ldots \ldots, \ldots$

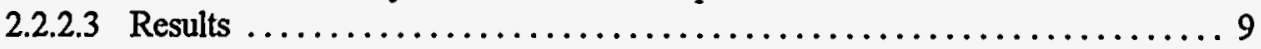

2.2.2.4 Instability Prediction During Startup using RAMONA-4B $\ldots \ldots \ldots \ldots \ldots$

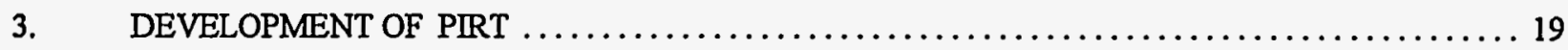

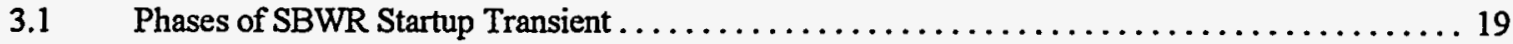

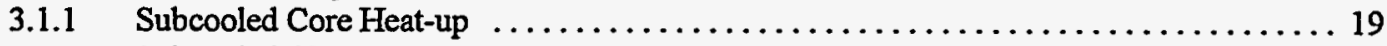

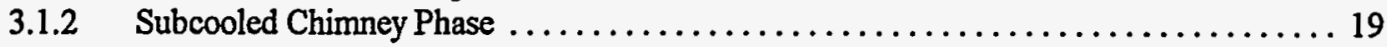

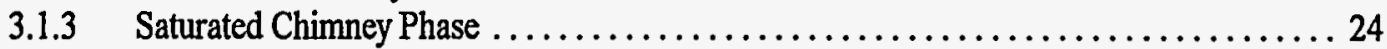

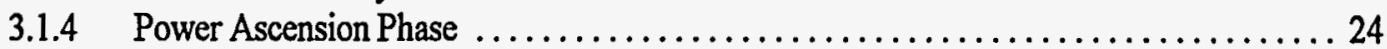

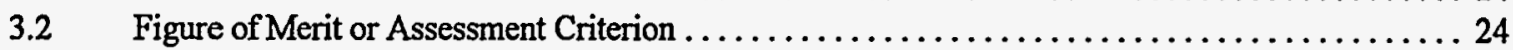

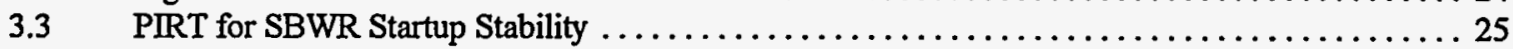

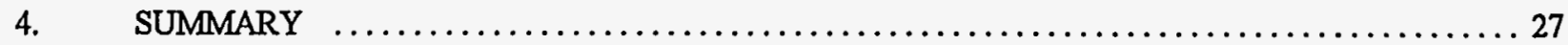

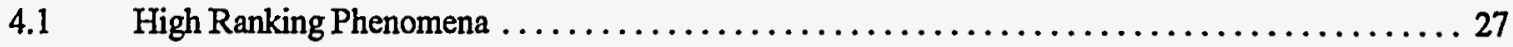

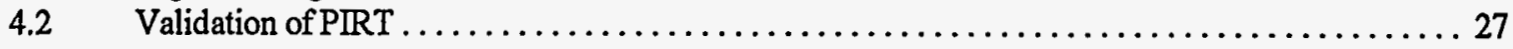

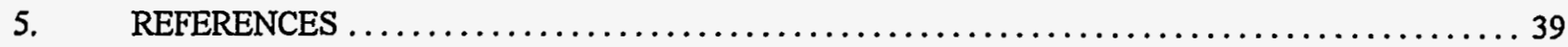

APPENDIX A (Intentionally left blank)

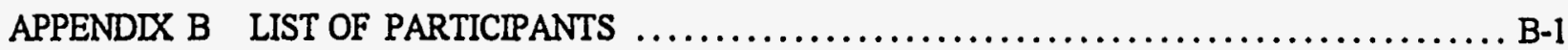

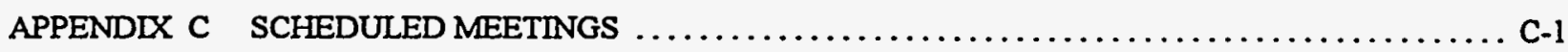

APPENDIX D MINUTES OF MEETING BETWEEN BNL STAFF, USNRC PERSONNEL AND EXTERNAL

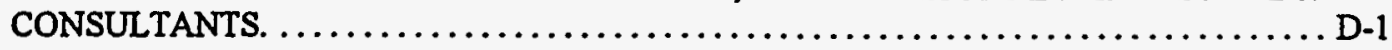

APPENDIX E DESCRIPTION OF COMPONENTS AND PHENOMENA $\ldots \ldots \ldots \ldots \ldots \ldots \ldots \ldots \ldots \ldots$ E-1

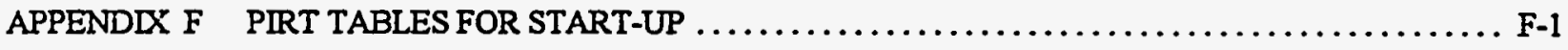




\section{LIST OF FIGURES}

Figure $2.1 \quad$ SBWR Pressure Vessel Isometric and the TRACG Model. $\ldots \ldots \ldots \ldots \ldots \ldots \ldots \ldots \ldots$

Figure $2.2 \quad$ Reactor Power Increase During SBWR Startup $\ldots \ldots \ldots \ldots \ldots \ldots \ldots \ldots \ldots \ldots \ldots$

Figure $2.3 \quad$ Reactor Power, Pressure, and Temperature for Case $2 . \ldots \ldots \ldots \ldots \ldots \ldots \ldots \ldots \ldots$

Figure $2.4 \quad$ Coolant and Saturation Temperatures at Chimney Bottom for Case $2 . . \ldots \ldots \ldots \ldots \ldots \ldots .8$

Figure 2.5 Coolant Velocity and Void Fraction at Channel Exit for Case $2 \ldots \ldots \ldots \ldots \ldots \ldots \ldots \ldots$

Figure 2.6 Power Ramp Curve Used for Base Case of RAMONA-4B Calculations $\ldots \ldots \ldots \ldots \ldots \ldots$

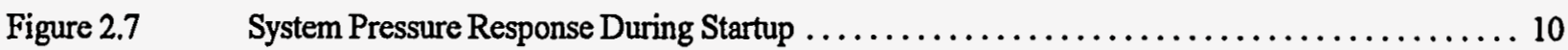

Figure 2.8 Total Core Inlet Flow Response During Startup for the Base Case $\ldots \ldots \ldots \ldots \ldots \ldots \ldots \ldots$

Figure 2.9 Individual Channel Flow Responses During Startup for the Base Case $\ldots \ldots \ldots \ldots \ldots \ldots 12$

Figure 2.10 Coolant Temperature Response During Startup for the Base Case $\ldots \ldots \ldots \ldots \ldots \ldots \ldots \ldots$

Figure 2.11 Core-Average Void Fraction During Startup for the Base Case $\ldots \ldots \ldots \ldots \ldots \ldots \ldots \ldots$

Figure 2.12 Total Vapor Generation Rate During Startup for the Base Case $\ldots \ldots \ldots \ldots \ldots \ldots \ldots \ldots \ldots$

Figure 2.13 Downcomer Collapsed liquid Level During Startup for the Base Case $\ldots \ldots \ldots \ldots \ldots \ldots \ldots$

Figure 2.14 Power Ramp Imposed as Boundary Condition for the Abnormal Startup Case $\ldots \ldots \ldots \ldots \ldots 16$

Figure $2.15 \quad$ System Pressure Response for the Abnormal Startup Case $\ldots \ldots \ldots \ldots \ldots \ldots \ldots \ldots \ldots \ldots$

Figure 2.16 Total Core Inlet Flow Response for the Abnormal Startup Case $\ldots \ldots \ldots \ldots \ldots \ldots \ldots \ldots$

Figure $2.17 \quad$ Zoomed Core Flow Oscillations for the Abnormal Startup Case $\ldots \ldots \ldots \ldots \ldots \ldots \ldots \ldots \ldots$

Figure $3.1 \quad$ Pressure and Power Characterization of SBWR Startup Phases $\ldots \ldots \ldots \ldots \ldots \ldots \ldots \ldots \ldots \ldots$

Figure 3.2 Coolant Temperature Characterization of SBWR Startup Phases $\ldots \ldots \ldots \ldots \ldots \ldots \ldots \ldots 21$

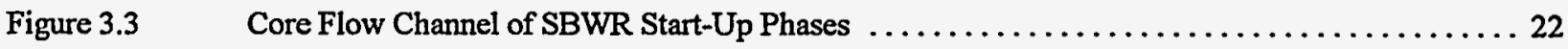

Figure 3.4a Typical BWR/4 Stability Map $\left(K_{\text {in }}=27.8, K_{\text {wit }}=0.14\right) \ldots \ldots \ldots \ldots \ldots \ldots \ldots \ldots \ldots \ldots \ldots \ldots \ldots \ldots$ (Ref. Lahey \& Moody, 1993, Fig. 7-10)

Figure 3.4b Conservative Stability Criterion for Density Wave $\ldots \ldots \ldots \ldots \ldots \ldots \ldots \ldots \ldots \ldots \ldots \ldots \ldots$ 


\section{LIST OF TABLES}

Table 2.1

Table 2.2

Table 3.1

Table 4.1

Table 4.2

Table 4.3

Table 4.4

Table 4.5

Table A.2

Table A.3

Table A.4

Table A.5

Table A.6

Table A.7

Table A.8

Table E.1

Table E.2

Table F.1

Table F.2

Table F.3

Table F.4
The TRACG Startup Simulation Cases.

Effect of Core Inlet Loss Coefficient on Abnormal Startup with RAMONA-4B. 15

Summary of SBWR Startup Transient Phases. 20

High Ranking Phenomena for Phase I: Subcooled Heatup 28

High Ranking Phenomena for Phase II: Subcooled Chimney . 29

High Ranking Phenomena for Phase III: Saturated Chimney 30

High Ranking Phenomena for Phase IV: Power Ascension to Operating Condition 32

Composite PIRT 34

Elevations within the SBWR A-7

SBWR Recirculation Pressure Drops A-8

Isolation Condenser A-8

PCCS Parameters A-9

Vertical Vent Parameters A-9

SRVs Parameters A. -9

Signal Activation Locations A-10

Detailed description of Components E-1

Detailed Description of Phenomena E-3

Phase I: Subcooled Heatup F-1

Phase II: Subcooled Chimney F-6

Phase III: Saturated Chimney F-11

Phase IV: Power Ascension to Operating Condition F-16 



\section{Executive Summary}

Phenomena Identification and Ranking Tables (PIRT) provide information about the phenomena and their importance to a set of selected parameters of a system such as a nuclear power plant. These tables contain a list of phenomena as they occur in components during a specific phase of a selected transient of interest. Tables also include the ranking of the phenomena as they affect the selected parameters which impact the safety of the plant. The PIRTs are specific to the selected plant and transient. The PIRTs represent a collective judgements of engineers who are knowledgeable about the plant and the transient of interest. PIRT provides a logical method of assessing the applicability of the code for modeling the transient. Furthermore, it also provides a way of planning and selecting the tests needed to assess the code.

In this report we have described the PIRT for a typical startup transient for Simplified Boiling Water Reactor (SBWR) [Kim, 1993 ]. The transient will start from a steady-state condition at low pressure (e.g., one atmosphere), low flow, and very low power. It proceeds with the increase in power (by withdrawing the control rods) and following a eight step startup procedure. The procedure does not provide any information on the control rod withdrawal sequences. Instead, GE described the power heat up patterns (power vs. time). The other systems which are involved are, main condenser for deaeration, Reactor Water Clean-up and Shutdown Cooling (RWCU/SDC) for coolant heating, and automatic feedwater controller for maintaining the level.

The startup procedure for the SBWR is important since the low-pressure and low-flow conditions prevailing in the early part of the transient may become a precursor to an instability. In a natural circulation system like the SBWR, the core flow rate is strongly coupled to the reactor power. The startup of SBWR begins with slow heat-up of the coolant in the reactor vessel followed by withdrawal of selected groups of control rods. Gradual increase of reactor power results in single phase natural circulation flow within the reactor while the system pressure is still very low. During this period, transition from a subcooled core to a saturated core with a subcooled chimney, may be accompanied by creation of large steam bubbles which can initiate geysering instability. A certain combination of pressure, flow and thermal-hydraulic conditions was required for geysering to occur in small scale laboratory experiments [Aritomi et al, 1990, Wang et al, 1994]. According to these research findings, out-of- phase geysering oscillations in two parallel channels are limited to low-pressure and low-flow conditions. A subcooled chimney induces condensation of the large bubbles from the heated channels, which leads to instability in the flow within the channels. At higher powers, a looptype instability may follow the geysering instability, where the flow in the downcomer and the core oscillate in phase. Finally, density-wave oscillations of higher frequencies can occur at a higher power if the power-to-flow ratio is sufficiently high. Although oscillations during the startup have been demonstrated in the laboratory experiments, the two recent startups of the Dodewaard reactor (a natural circulation BWR) in 1992 have not shown any type of instability [Nissen et al, 1992]. However, there are sufficient differences among the SBWR, Dodewaard and the laboratory experiments, that the conclusions made from these tests can not be directly applied to the SBWR.

The transient due to stratup procedure as described earlier has been divided into four distinct phases for developing PIRTs. These are; Subcooled Core Heat-Up, Subcooled Chimney, Saturated Chimney and Power Ascension Phases,

The Subcooled Heat-up Phase (Phase I) includes the first three steps of GE's startup procedure. The transition from this phase to Subcooled Chimney Phase is with the onset of Net Vapor Generation (NVG). The NVG is associated with sustained bubble concentration in the channels and a consequent increase in buoyancy induced flow.

During Subcooled Chimney Phase (Phase II) and also Phase I, most of the coolant within the chimney remains subcooled with the lowest subcooling at the top. Migration of the vapor bubbles to the chimney results in condensation in the subcooled fluid and a consequent heating of the coolant. The saturation condition at the inlet of the chimney is identified as the transition from this phase to the next phase, Saturated Chimney Phase.

During the Saturated Chimney Phase (Phase III), the power increase continues with the withdrawal of the control rods. There is flashing in the chimney which will lead to an increase in buoyancy forces and natural circulation 
flow. There is condensation taking place in the chimney fluid. The reactor is susceptible to a loop type of oscillation. This phase is characterized with large subcooling, low power and low voids in the core. The transition from this phase to Power Ascension Phase occurs when there is a possibility of density waves. There are two possible ways to find this transition, either by stability map [Lahey, 1976] based on minimum $\mathrm{N}_{\text {pch }}$ or by a simple criteria, proposed by Prof. Griffith, based on the ratio of single phase pressure drop to total pressure drop being less than $1 / 3$.

The last phase is the Power Ascension Phase (Phase IV), during which reactor power is increased to full power by withdrawing the control rods. The level is maintained by feedwater flow controller. The core flow and system pressure, both increase. The pressure drops at the core inlet, at the core exit, and kinetic feedback play important roles in determining the possibility of density waves.

The assessment of the SBWR startup stability is based on the Minimum Critical Power Ratio (MCPR) as the figure of merit. This is appropriate because the thermal-hydraulic instability usually induces flow and power oscillations, which tend to reduce the MCPR if the amplitude of the oscillations is substantial. Large power oscillations can lead to post-CHF conditions if the oscillations continue for a long period of time. The post-CHF condition is closely related to the clad temperature, void fraction, and flow rate, all of which will affect the MCPR. Therefore, by using MCPR as the figure of merit (or assessment criterion), the key thermal-hydraulic parameters are adequately covered.

The BNL team identified the phenomena for the four phases. The phenomena in each phase were ranked based on their impact on the figure of merit. A total of 7 meetings were held with a BNL team and a preliminary PIRT was produced. A final meeting was held with the BNL team and outside participants to review the PIRT, and a modified PIRT was developed. The SBWR plant has been divided into 10 components. The team identified 33 distinct phenomena aredescribed in the body of this report. The Phase I has 28 applicable phenomena and ranking with 17 ranked low, 6 ranked medium and 5 ranked high. The Phase II has 39 ranked phenomena with 18 ranked low, 13 ranked medium and 8 ranked high. The Phase III has 47 ranked phenomena with 22 ranked low, 10 ranked medium and 15 ranked high. The last phase (Phase IV), has 46 ranked phenomena with 16 ranked low, 12 ranked medium and 18 ranked high.

A review of PIRT indicated that the 3-D kinetics and associated feedbacks, stored energy and the single phase pressure drop in the core were all rated high for all four phases. The phenomena related to separator/dryer components and level motion in the steam dome were also rated high for all the phases. The control system also appears in all four phases but the specific control system required in a phase, vary from phase to phase. The first two phases need level control through RWCU system, while the third and fourth phases require level control through feedwater system. The last phase also has an active pressure regulator. The phenomena related to the chimney component play active roles in the last three phases and phenomena such as evaporation, subcooled boiling and two phase pressure drop become important.

PIRT presented in this report is based on judgement of the participating engineers, the analysis of the start-up transients at BNL with RAMONA-4B and GE's analysis in TRACG, and some experiments. While the PIRT presented here can be used as the basis of code development, code assessment and planning for tests, it should be treated as a living document which will be revised as new information becomes available. The revision will take place in the identification of phenomena and their ranking. The existence of new phenomena can only be obtained from tests. The ranking of the identified phenomena can be validated in three ways; Sensitivity Calculations, Non-dimensional Analysis, and Scaled Integral Tests. 
Phenomena Identification and Ranking Tables (PIRT) provide information about the phenomena and their importance to a set of selected parameters of a system such as a nuclear power plant. These tables contain a list of phenomena as they occur in components during a specific phase of a selected transient of interest. Tables also include the ranking of the phenomena as they affect the selected parameters which impact the safety of the plant. The PIRTs are specific to the selected plant and transient.

The PIRT was first proposed as an integral part of the Code Scaling and Uncertainty (CSAU) [Boyack et el, 1989] evaluation methodology for a computer code used for safety analyses. The PIRT was used there to identify the important phenomena for estimating the uncertainty in the safety parameter (Peak Clad Temperature (PCT) for LOCA) due to the uncertainty in the models for these important phenomena. However, the PIRT has wider applications. PIRT provides a logical method of assessing the applicability of the code for modeling the transient. Furthermore, it also provides a way of planning and selecting the tests needed to assess the code.

The PIRTs represent a collective judgements of engineers who are knowledgeable about the plant and the transient of interest. Usually a team of cognizant engineers is formed. In the first step, the team selects a plant and a transient. In the second step, the team reviews the course of the transient and divides it into various phases with distinct characteristics. The team then identifies possible phenomena for each component during each phase. If the team is large enough and has good knowledge of the system and the transient, there is less likelihood of missing an important phenomenon.

In the third step of the development of PIRT, a figure of merit is selected. In case of nuclear reactors, it is generally the PCT, Minimum Critical Power Ratio (MCPR), containment pressure or suppression pool temperature. In some cases, a lower-level parameter could be chosen such as reactor pressure vessel inventory instead of the PCT. For the thermal-hydraulic instability, decay ratio or the peak amplitude of power oscillations could be used as the figure of merit.

The fourth step in this process is to rank the phenomena identified in the second step for each phase. The ranking is determined on the basis of the effects of phenomena on the figure of merit. The ranking could be numerical, varying from 1 to 9, or verbal; such as high, medium or low. Unless there is very definite understanding of how the phenomena affect the figure of merit, it is safer to use the verbal ranking. The phenomena ranked high should be modelled with good fidelity. The phenomena ranked medium should be modelled, but with less fidelity than the highrank phenomena. The low-rank phenomena should be modelled, but need no assessment.

In this report we will describe the PIRT for a typical startup transient for Simplified Boiling Water Reactor (SBWR) [Kim, 1993 ]. The transient will start from a steady-state condition at low pressure (e.g., one atmosphere), low flow, and very low power. It proceeds with the increase in power (by withdrawing the control rods). Section 2 describes the start-up procedure proposed by GE and presents the results of the analysis performed by GE and BNL. These analyses provide the background to assist in identifying the phases of the start-up transient. Section 3 describes the various phases of the transient and the PIRTs. Section 4 summarizes the important results from the development of the PIRTs. 
The startup procedure for the SBWR is important since the low-pressure and low-flow conditions prevailing in the early part of the transient may become a precursor to an instability . In a natural circulation system like the SBWR, the core flow rate is strongly coupled to the reactor power. The startup of SBWR begins with slow heat-up of the coolant in the reactor vessel followed by withdrawal of selected groups of control rods. Gradual increase of reactor power results in single phase natural circulation flow within the reactor while the system pressure is still very low. During this period, transition from a subcooled core to a saturated core with a subcooled chimney, may be accompanied by creation of large steam bubbles which can initiate geysering instability. A certain combination of pressure, flow and thermal-hydraulic conditions was required for geysering to occur in small scale laboratory experiments [Aritomi et al, 1990, Wang et al, 1994]. According to these research findings, out-of-phase geysering oscillations in two parallel channels are limited to low-pressure and low-flow conditions. A subcooled chimney induces condensation of the large bubbles from the heated channels, which leads to instability in the flow within the channels. At higher powers, a looptype instability may follow the geysering instability, where the flow in the downcomer and the core oscillate in phase. Finally, density-wave oscillations of higher frequencies can occur at a higher power if the power-to-flow ratio is sufficiently high. Although oscillations during the startup have been demonstrated in the laboratory experiments, the two recent startups of the Dodewaard reactor (a natural circulation BWR) in 1992 have not shown any type of instability [Nissen et al, 1992]. However, there are sufficient differences among the SBWR, Dodewaard and the laboratory experiments, that the conclusions made from these tests can not be directly applied to the SBWR. Assessment of the RAMONA-4B code with these tests will provide the confidence in the simulation of the SBWR startup.

Simulations of the SBWR startup transient have been performed at Brookhaven National Laboratory (BNL) using the RAMONA-4B code. This code uses 3D neutron diffusion theory for neutron kinetics and a drift-flux model for thermal hydraulics. In order to simulate various startup conditions of the SBWR, a tabular function of power vs. time was imposed as a boundary condition and thermal-hydraulic calculations were performed with multiple parallel channels in the core. Since information on the spatial and temporal movements of the control rods are not known at present, the startup transient simulation did not exercise the 3D neutronics capability of RAMONA-4B. Thermalhydraulic calculations over a long period of time are needed for the startup transient. Simulations of the SBWR startup transient were also performed by GE using the TRACG code [Kim, 1993]. The results presented in this report will refer to some of the findings of GE's analysis.

\subsection{Normal Startup Procedure}

GE has described the general procedures [Kim, 1993] of starting SBWR from low-power, low-pressure, and subcooled conditions to the full-power, full-pressure, and saturated conditions. The procedures do not provide any information on the control rod withdrawal sequences. Instead, GE described the power heatup patterns (power vs. time).

A brief description of the proposed SBWR normal startup procedure is given below:

1. Heat reactor coolant to $80^{\circ} \mathrm{C}$ at atmospheric pressure.

- Terminate shutdown cooling operation to begin warmup of reactor coolant by core decay heat or electric heater or by a combination of these two.

- $\quad$ Align the Reactor Water Cleanup and Shutdown Cooling (RWCU/SDC) system to operate in the coolant heatup mode to heat the coolant to $80^{\circ} \mathrm{C}$.

- $\quad$ Continue the Control Rod Drive (CRD) purge to cool the CRD.

2. Deaerate reactor coolant. 
- Draw vacuum at main condenser.

- Open main steamline drain valves to establish a partial vacuum at the reactor dome (Turbine bypass valves and turbine control valves closed).

- $\quad$ Continue deaeration to reduce dissolved oxygen concentration within the specified limit.

3. Start up reactor by withdrawing control rods to establish reactor criticality (Reactor dome saturated at about 8 psia, i.e., saturated startup).

Remove water during the early stages of heatup via RWCU/SDC system to control water level.

4. Heat up reactor at a rate $s 55^{\circ} \mathrm{C} / \mathrm{hr}$ limit.

- Control reactor power by control rod motion.

- Control reactor pressure by turbine bypass valve.

5. As pressure increases, align RWCU/SDC system in cleanup mode (Suction from bottom drain and/or RPV side nozzle).

- $\quad$ Reduce thermal stratification.

- Control reactor water level.

- Maintain reactor water chemistry.

6. Automatic feedwater/level control is established at about 25 bars.

7. Turbine is synchronized at about $10 \%$ power and 70 bars.

8. Continue power ascension.

\subsection{SBWR Plant Startup Simulation}

According to the startup procedures presented in the SSAR [GE, 1992], and reported by GE [Kim, 1993], several components of the reactor are used to perform special functions during the startup. For example, the RWCU/SDC and CRD are used to heat up the reactor coolant to $80^{\circ} \mathrm{C}$. These components are currently not available in RAMONA-4B. Therefore, alternative use of the available features of the code have been made to approximate the functions of these components, wherever appropriate.

\subsubsection{Simulation of SBWR Startup by GE}

Analytical simulation of the SBWR startup was performed by GE using the TRACG code. A wide range of the reactor vessel heatup rates were used to evaluate the thermal-hydraulic behavior in the reactor vessel and examine the possibility of geysering oscillations during normal plant startup. Also, some abnormal events were analyzed in an attempt to identify the geysering instability region for SBWR. The key results of the study are presented in this section. 


\subsubsection{TRACG Model}

The TRACG model of the SBWR reactor vessel is shown in Figure 2.1. The model includes VESSEL, CHANNEL, BREAK, and FILL components. The VESSEL component consists of 15 axial levels representing lower plenum, core, chimney, steam separator/dryer and reactor dome, and 4 rings in the radial direction: 3 inner rings inside the core shroud and one ring for the downcomer. Fuel bundles are grouped into CHANNEL components. Each fuel channel is divided into 28 nodes. The chimney is divided into 5 nodes.

The TRACG startup simulation was performed under the following conditions:

1. Initial Conditions

- $\quad \mathrm{RPV}$ water temperature $=80^{\circ} \mathrm{C}$ (Dome pressure $=0.552 \mathrm{~atm}$ )

(The analysis starts from Step 3 of the startup procedure in Section 2.1)

- Core inlet subcooling $=43^{\circ} \mathrm{C}$

2. Feedwater temperature $=80^{\circ} \mathrm{C}$

3. Reactor water cleanup flow $=10.73 \mathrm{Kg} / \mathrm{sec}$

4. Control rod drive flow $=3.84 \mathrm{Kg} / \mathrm{sec}$

\subsubsection{Analysis of Results from TRACG}

The TRACG simulation of the normal startup of SBWR considered a wide range of the heatup rates expected during the normal plant startup. The cases analyzed are listed in Table 2.1. Figure 2.2 presents the power ascension curves used for these cases. Some of the key results for Case 2, most typical for startup, are shown in Figures 2.3 through 2.5.

Table 2.1

The TRACG Startup Simulation Cases

\begin{tabular}{|c|c|c|c|c|c|}
\hline Case & $\begin{array}{c}\text { Power Ramp } \\
(\mathrm{MW} / \mathrm{hr})\end{array}$ & $\begin{array}{c}\text { Temperature } \\
\left({ }^{\circ} \mathrm{C} / \mathrm{hr}\right)\end{array}$ & Pressure & Flow & Figure \\
\hline 1 & 10 & 30 & Increasing & Increasing & 2.2 \\
\hline 2 & 20 & 42 & Increasing & Increasing & 2.2 \\
\hline 3 & 30 & 58 & Increasing & Increasing & 2.2 \\
\hline
\end{tabular}

\subsubsection{Simulation of SBWR Startup by BNL using RAMONA-4B Code}

SBWR startup transient simulations have been performed using the RAMONA-4B code at BNL. This code has been upgraded for use at low pressures that prevail during the early phase of the startup transient. The startup transient 

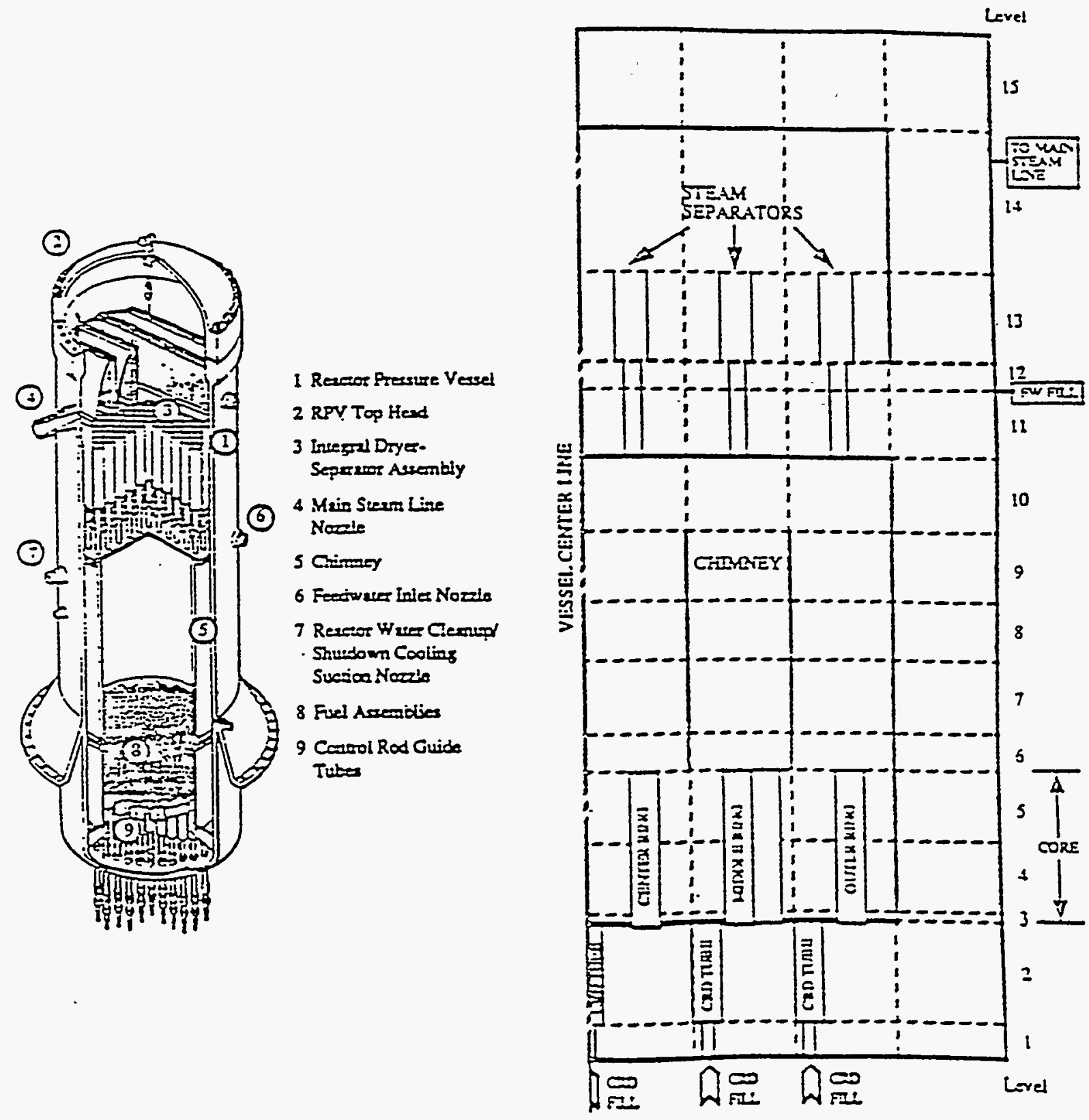

Figure 2.1 SBWR Pressure Vessel Isometric and the TRACG Model. 


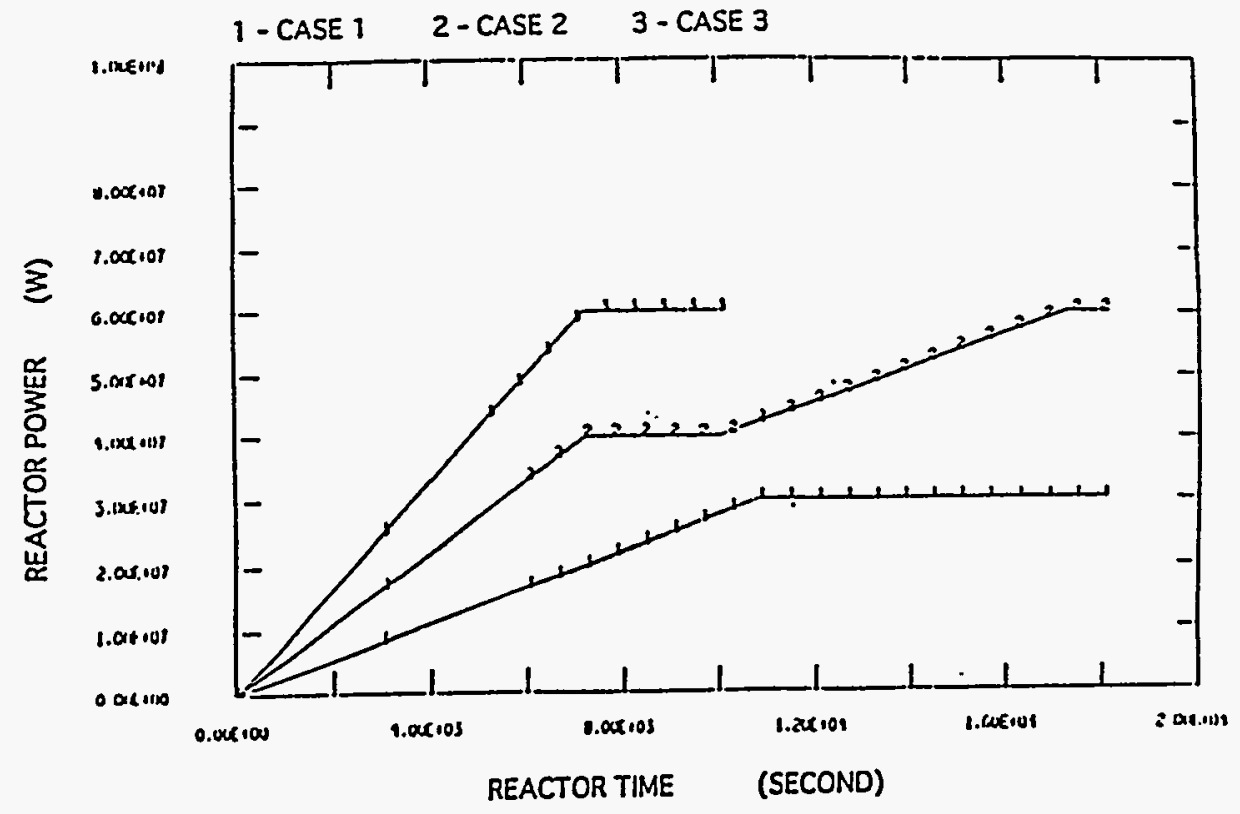

Figure 2.2 Reactor Power Increase During SBWR Startup.

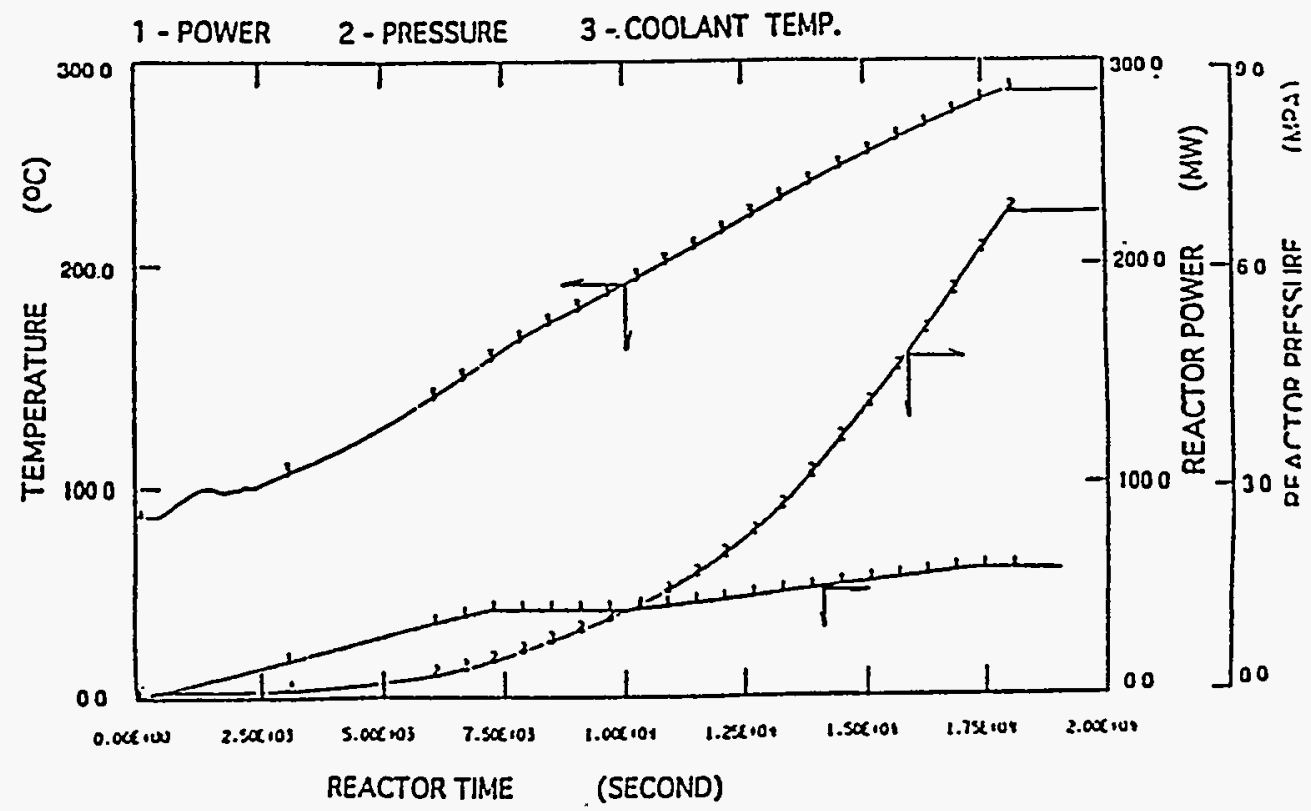

Figure 2.3 Reactor Power, Pressure, and Temperature for Case 2. 


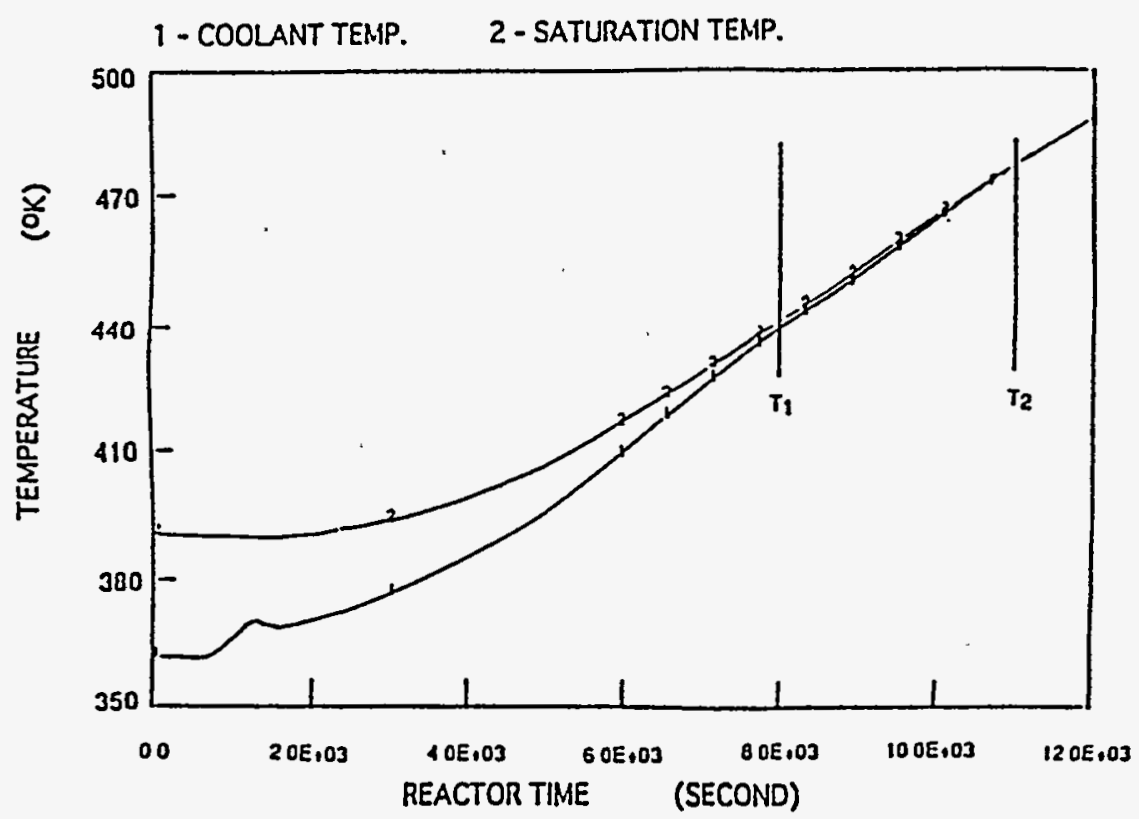

Figure 2.4 Coolant and Saturation Temperatures at Chimney Bottom for Case 2.

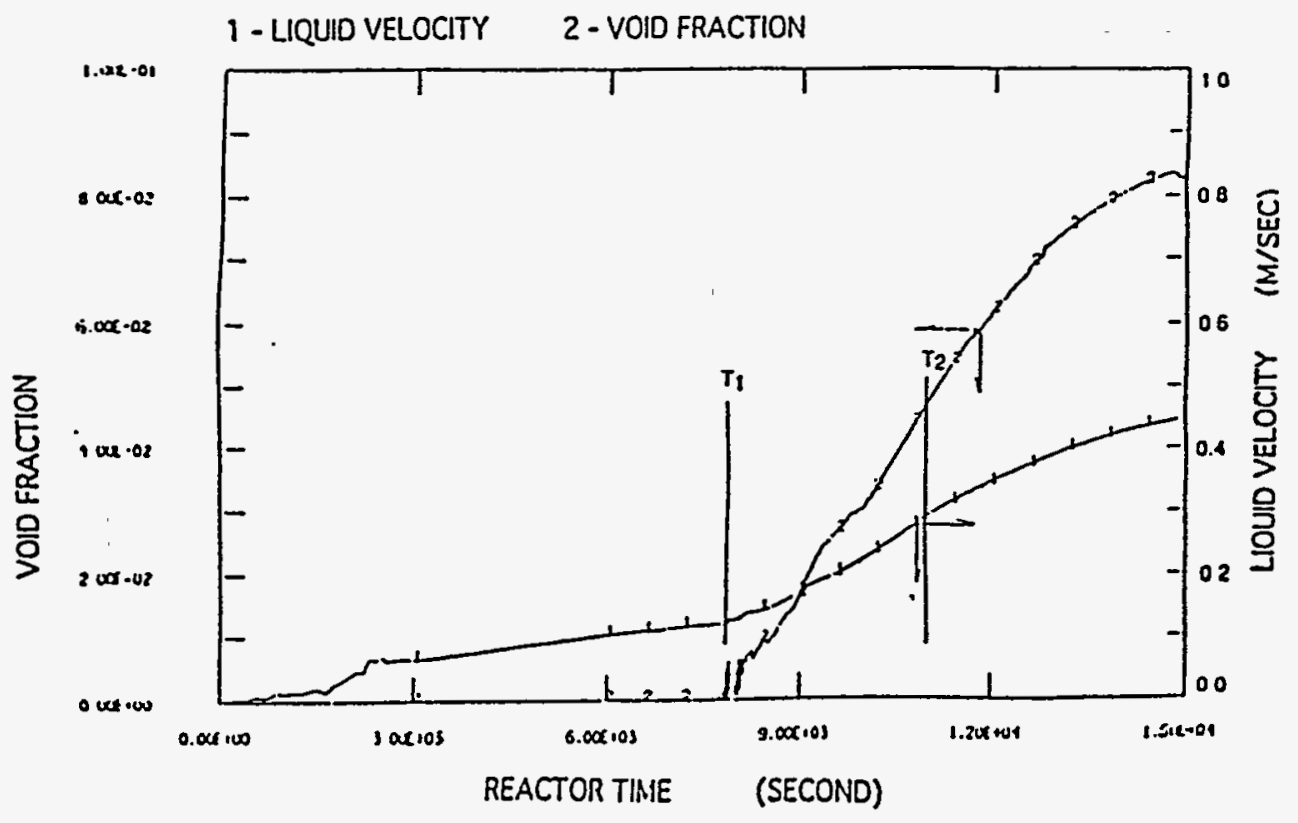

Figure 2.5 Coolant Velocity and Void Fraction at Channel Exit for Case 2. 
is usually of a very long time period ( 5 to 12 hours), during which the reactor thermal-hydraulic conditions vary from a subcooled reactor at near atmospheric conditions to a saturated core at full power operating conditions.

The inventory of mass within the reactor vessel has a large thermal capacity and thereby, influences the startup transient. It has the potential of behaving like a large heat sink during startup and conversely, like a heat source during shutdown. Influence of the structural materials of the reactor vessel on the transient has been considered in the simulations.

Buoyancy induced flows within the core channels are strongly coupled to the reactor power. Since the power increases with time during the startup, the flow rate generally increases accordingly. The thermal-hydraulic stability is closely related to the power-to-flow ratio in the core. In natural circulation systems, the driving head, frictional and formloss pressure drops in the flow loop determine the net flow rate. The relationship between the pressure drops and flow is implicit in nature since they are mutually dependent. Stability predictions should therefore use a realistic model for the pressure drops. Flow-dependent loss coefficients are important for the flow prediction in natural circulation systems. Models for these loss coefficients are available in RAMONA-4B. Accurate values of the coefficients for the model are needed for realistic prediction of the pressure drops in the SBWR.

The process of heat transfer during the startup is a combination of boiling and condensation. Accuracy of the models for these heat transfer processes will have a direct impact on the predicted phase change, thermal and flow characteristics. Net vapor generation rate will influence the void fraction and flow as well.

\subsubsection{RAMONA-4B Model}

GE has provided a startup procedure [Kim, 1993] for the SBWR, and simulated the startup with the TRACG code. In these simulations, GE used power ramps to represent power ascension due to control rod withdrawal. Since the information on the control rod withdrawal sequences was not given, the RAMONA-4B simulation of the SBWR startup also used the GE's power ascension curves, initial and boundary conditions (excluding RWCU flow). Therefore, the startup transient calculation can be performed with the thermal-hydraulic part of the code only.

The input deck prepared for the SBWR startup transient consists of four parallel channels (including the bypass channel) to represent the full core. The chimney, steam separator, downcomer and lower plenum of the SBWR were also modeled.

\subsubsection{Initial and Boundary Conditions for Startup}

The initial conditions were selected to be close to the actual values proposed by GE. The startup transient has a very long time period ( 5 to 12 hours). The initiation and completion times of the selective processes during startup were not clearly identified by GE [Kim, 1993]. Estimation of certain boundary conditions were made based on the results of TRACG. A power ramp of $20 \mathrm{MW} / \mathrm{hr}$ has been imposed as a boundary condition, which corresponds to a heatup rate of $42^{\circ} \mathrm{C} / \mathrm{sec}$ (GE's Case 2).

Turbine Control Valve (TCV) remained closed during the transient, allowing reactor pressure to rise. Figure 2.6 shows the power ramp curve used for the simulation of the base case as proposed by GE [Kim, 1993].

\subsubsection{Results}

During the early phase of SBWR startup, the RWCU/SDC systems are activated to operate with special modes of operation. These systems have not been modeled in RAMONA-4B. Therefore, simulation of continuously recirculating flows from these systems to the reactor is not possible at the present time. However, the magnitude of these 


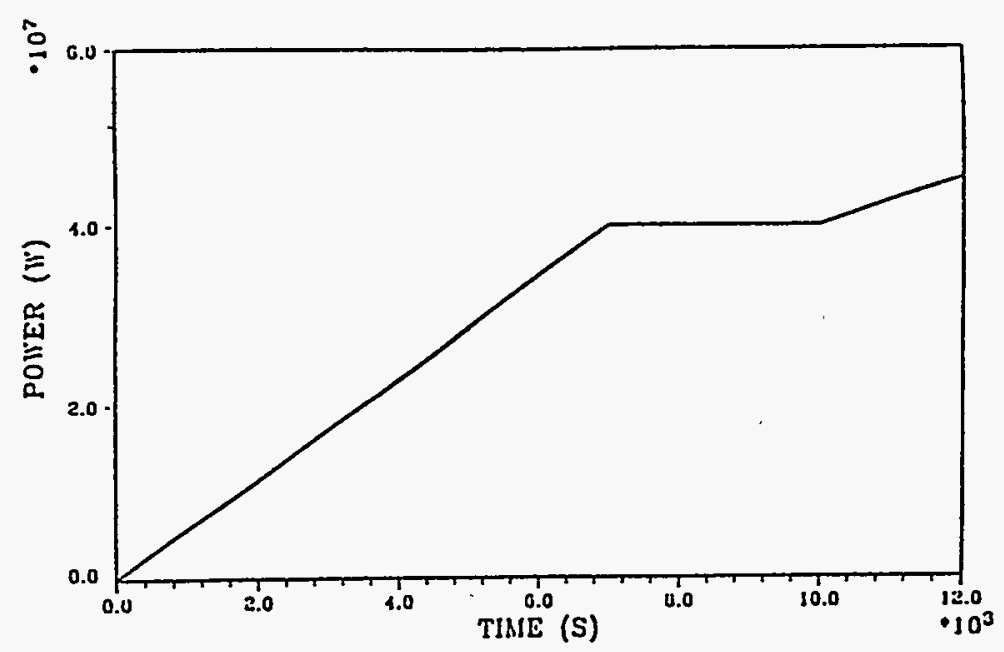

Figure 2.6 Power Ramp Curve Used for Base Case of RAMONA-4B Calculations

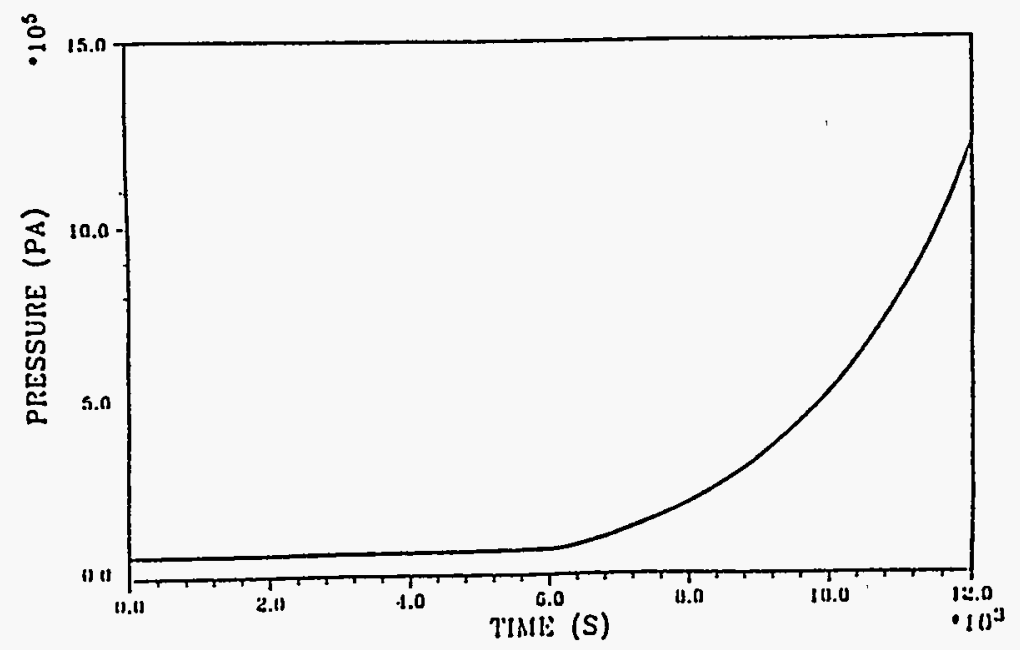

Figure 2.7 System Pressure Response During Startup 
flows are small compared to the core flow rate during startup, and the effect of these flows is to heat up the reactor water and prevent stratification in the lower plenum. This analysis assumes the reactor coolant to be at $40^{\circ} \mathrm{C}$ at the beginning of the transient. In the second phase of the startup process, the RWCU and SDC systerns are used to control the reactor water level. Since it is unavailable in RAMONA-4B, this function was not used in the simulation. In this section we present the results of calculations for the base case, which was run for 12,000 seconds.

\section{Pressure Rise During Startup}

Pressure rise in the dome during the startup is a combined result of heating by the power ramp, level rise due to thermal expansion, and net vapor generation rate in the reactor. Due to incompressibility of the liquid, the level rise and its effect on pressure is negligible during the early phase. Figure 2.7 shows the result obtained for the pressure response during the startup. The results of RAMONA-4B calculations indicate that sustained bubble concentration begins approximately at onset of net vapor generation. Since the TCV and bypass lines remained closed, this resulted in additional rise in pressure.

\section{Core Flow Rate During Startup}

The low-power and low-pressure condition in the early phase of the startup results in a single-phase natural circulation flow in the core. For a given power, the predicted flow for steady state is dependent upon the core inlet loss coefficients for the coolant channels. The total core inlet flow during the startup transient is shown in Figure 2.8. The core flow is the sum of the flows through the 3 heated channels and the unheated bypass channel as shown in Figure 2.9. The flow through the two larger heated channels are equal, while the flow through the orificed channel is less than the bypass channel. Change in liquid density during heat up causes the lighter fluid to rise upward. Recirculation of the hot fluid from chimney through the downcomer results in a continuous rise in coolant temperature. The flows through the channels increase rapidly at the onset of vapor generation in the core due to the enhanced driving potential. This is due to the large density change associated with phase change occurring at 6000 seconds. However, the flow starts to decrease at about 6200 seconds as the result of void collapse in the core following the pressure rise. The qualitative nature of the results are acceptable; however, an accurate quantitative analysis would require further assessment of the vapor generation and condensation models for low-pressure conditions.

\section{Liquid Temperature During Startup}

The increase in liquid temperature during the startup is monotonic with time. There is an axial gradient in temperature as shown in Figure 2.10. The liquid temperature in the core follows the saturation temperature at that axial location after the onset of net vapor generation at approximately 6000 seconds. Since the system pressure increases with time, the liquid temperature also follows this behavior.

\section{Void Fraction During Startup}

The core-average void fraction predicted by RAMONA-4B for the startup transient is presented in Figure 2.11 . Subcooled vapor generation in the core begins in the initial phase of the startup transient. Since the bulk fluid in the channels remain subcooled in this phase, condensation of the vapor takes place until net vapor generation begins at saturation. Void fraction in the core increases rapidly with time until, the pressure rise and the corresponding increase in saturation temperature cause the vapor to condense. The magnitude of core averaged void fraction shown in Figure 2.11 is very small. Thus, a small change in saturation temperature can cause condensation of the vapor. In addition, increase in the core flow rate causes the vapor to be carried away from the core region. This is evident in Figure 2.11 beyond 6200 seconds of the transient. Depending upon the rate of vapor generation due to the wall heat transfer and the degree of subcooling in that vicinity, the net vapor generation will be noticeable. Figure 2.12 shows that the net vapor generation rate in the core continues to rise until 10,000 seconds. The pressure rise caused by this vapor generation and 


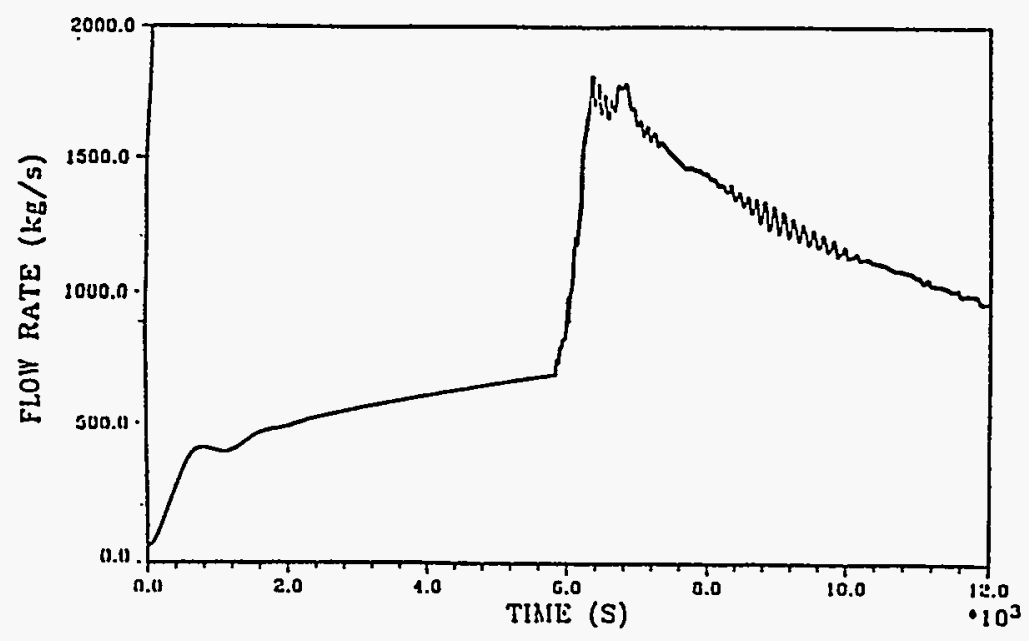

Figure 2.8 Total Core Inlet Flow Response During Startup for the Base Case

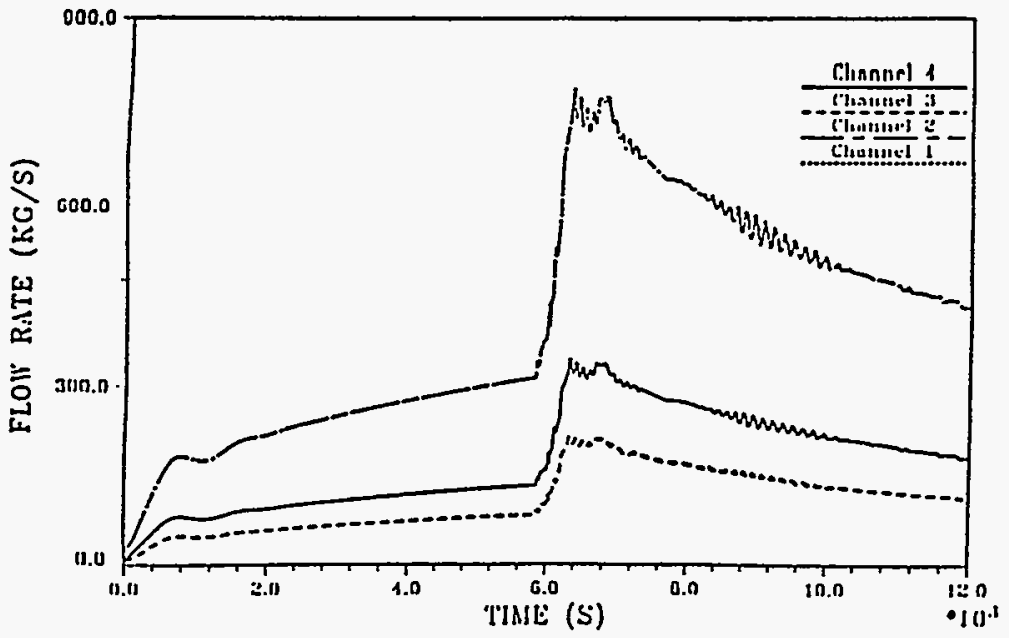

Figure 2.9 Individual Channel Flow Responses During Startup for the Base Case 


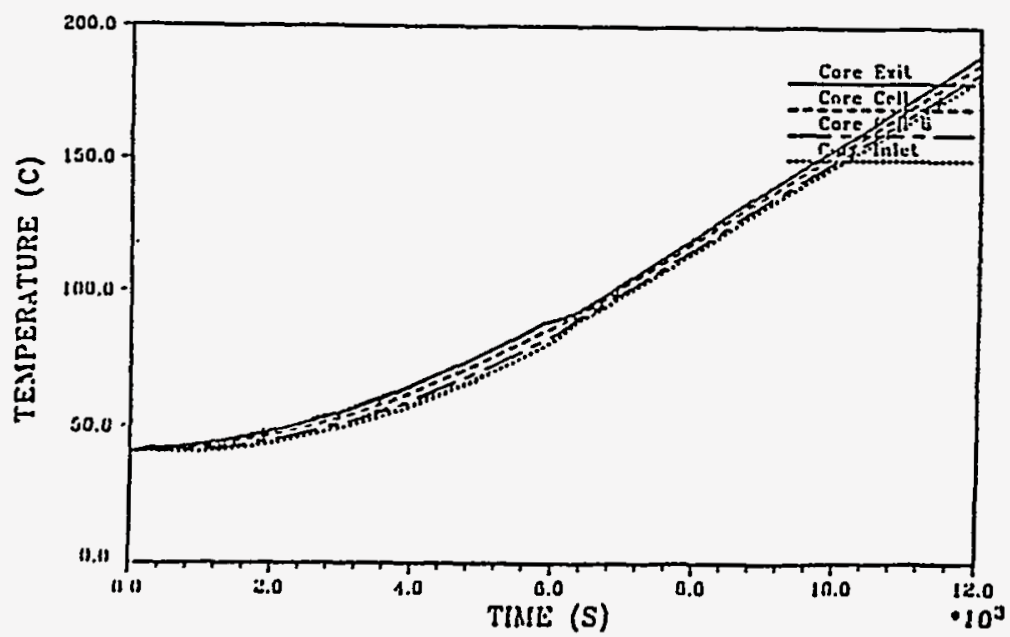

Figure 2.10 Coolant Temperature Response During Startup for the Base Case

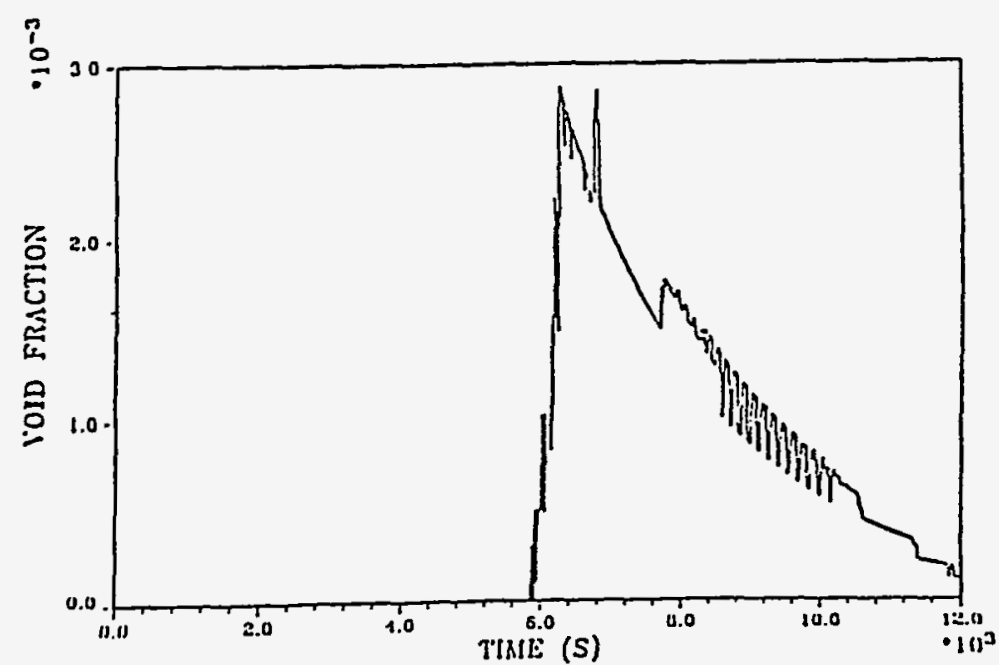

Figure 2.11 Core-Average Void Fraction During Startup for the Base Case 


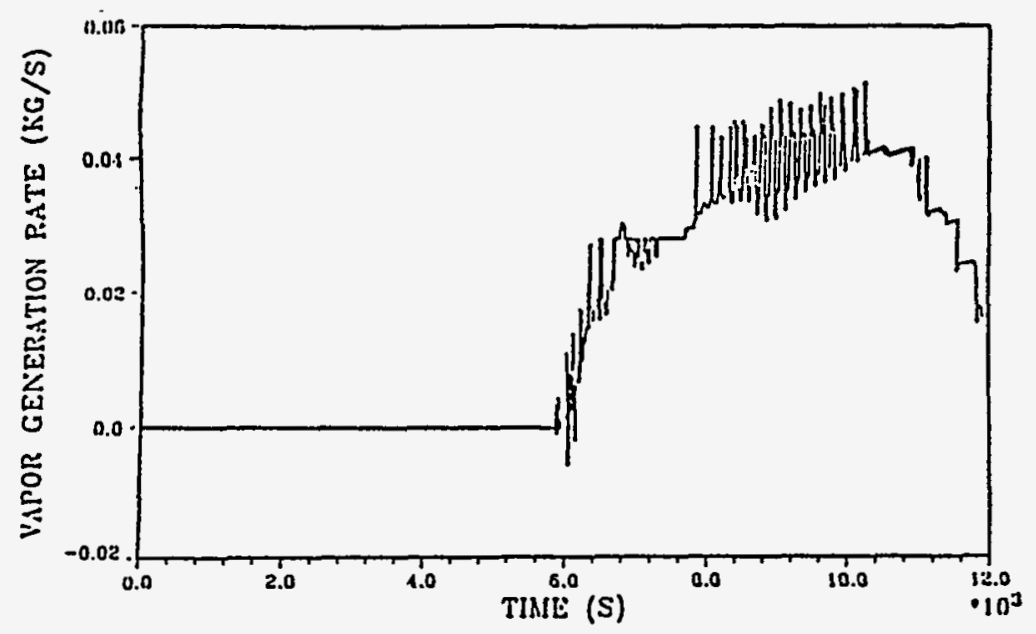

Figure 2.12 Total Vapor Generation Rate During Startup for the Base Case

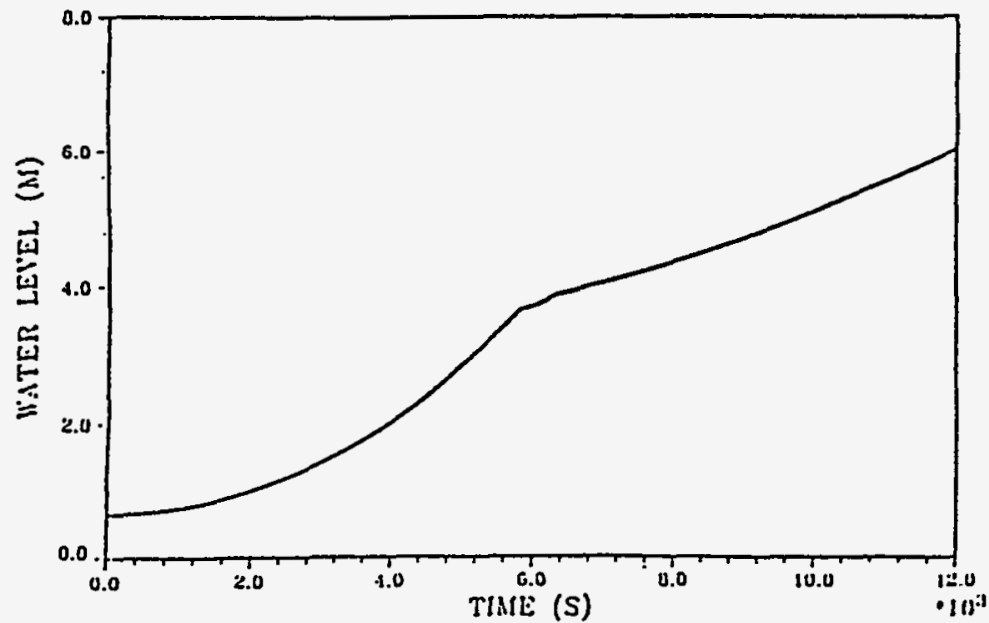

Figure 2.13 Downcomer Collapsed liquid Level During Startup for the Base Case 
the associated level swell result in a rapid collapse of voids. Control of the rate of system pressure rise, using the bypass valve, is necessary to prevent this loss of voids, which results in a decrease of the core flow rate.

\section{Collapsed Liquid Level During Startup}

It is important to maintain a desired liquid level in the vessel during the startup process. Since the liquid level is not controlled in the present simulation through the RWCU and SDC systems, rapid increase in the water level caused by thermal expansion and vapor generation can be seen in Figure 2.13. This level rise in the dome has resulted in a reduction in steam volume and a subsequent enhanced rise in pressure.

\subsubsection{Instability Prediction During Startup using RAMONA-4B}

In order to understand the phenomena of flow oscillations during the startup, several additional cases were analyzed with special boundary conditions. A rapid increase of power with a ramp from $20 \mathrm{~kW}$ to $140 \mathrm{MW}$ within 0.2 second at time zero was imposed as a boundary condition (see Figure 2.14) through the input, as proposed by GE [Kim, 1993]. The startup transient proceeded similarly to the base case. The pressure was held constant once it reached 0.19 $\mathrm{MPa}$, at which time oscillations in the core flow were predicted to begin. This combination of pressure, flow and power where TRACG also predicted oscillations [Kim, 1993], was identified as one of unstable regions by GE. GE maintains that during a normal startup of the SBWR, the reactor is not expected to attain this condition. Figures 2.15 and 2.16 show the pressure and core inlet flow rates, respectively, during a 3000-second transient. Magnification of the flow oscillations are presented in Figure 2.17, where the oscillations are seen to continue in time with a fixed amplitude of 47 $\mathrm{kg} / \mathrm{sec}$ and a period of 42.4 seconds. According to Figure 2.18, the net vapor generation rate oscillates with the same frequency as a result of consecutive vaporization and condensation. The oscillations are therefore condensation induced.

Using RAMONA-4B, the effect of core inlet loss coefficients on the flow oscillations discussed above, was investigated. Several cases were analyzed with the same boundary conditions and different initial flow conditions. The steady-state flow for a given power corresponds to the core inlet loss coefficients shown in Table 2.2. The amplitude of flow oscillations is seen to increase with decrease in the core inlet loss coefficient, which corresponds to the stability of the single-phase flow existing at the core inlet. The initiation of oscillations occurs between 1520 to 1600 seconds, which correspond to the pressure reaching $0.19 \mathrm{MPa}$ in all cases. The period of oscillations ranges from 31.8 to 46.7 seconds. The TRACG Simulation for a similar case predicted oscillations of a period of approximately 50 seconds with a larger amplitude. The peak void fraction of RAMONA-4B calculation is less than that of TRACG, which is probably due to the differences in the vapor generation models.

Table 2.2

\begin{tabular}{|c|c|c|c|c|}
\hline \multicolumn{5}{|c|}{ Effect of Core Inlet Loss Coefficient on Abnormal Startup with RAMONA-4B } \\
\hline \hline $\begin{array}{c}\text { Core Inlet Loss } \\
\text { Coefficient }\end{array}$ & $\begin{array}{c}\text { Initiation Time of } \\
\text { Oscillation (sec) }\end{array}$ & $\begin{array}{c}\text { Amplitude of } \\
\text { Oscillation (kg/sec) }\end{array}$ & $\begin{array}{c}\text { Period of } \\
\text { Oscillation (s) }\end{array}$ & $\begin{array}{c}\text { Average Core Flow } \\
\text { Rate (kg/s) }\end{array}$ \\
\hline 67.9 & 1600 & 38 & 46.7 & 2600 \\
\hline 44.5 & 1580 & 47 & 42.4 & 3000 \\
\hline 21.4 & 1540 & 64 & 35.9 & 3700 \\
\hline 12.2 & 1520 & 76 & 31.8 & 4200 \\
\hline
\end{tabular}




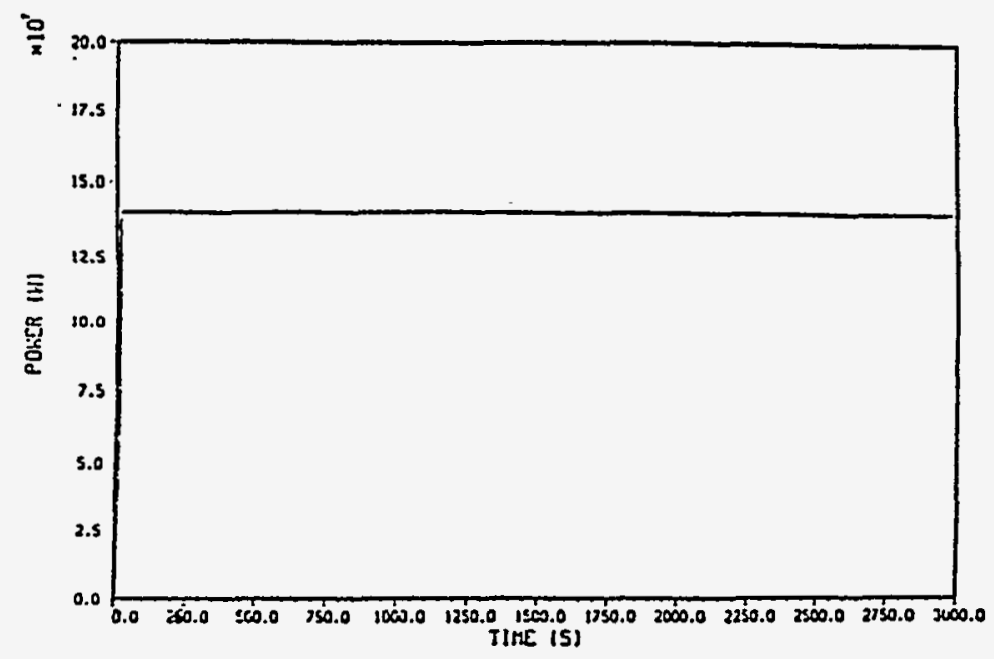

Figure 2.14 Power Ramp Imposed as Boundary Condition for the Abnormal Startup Case

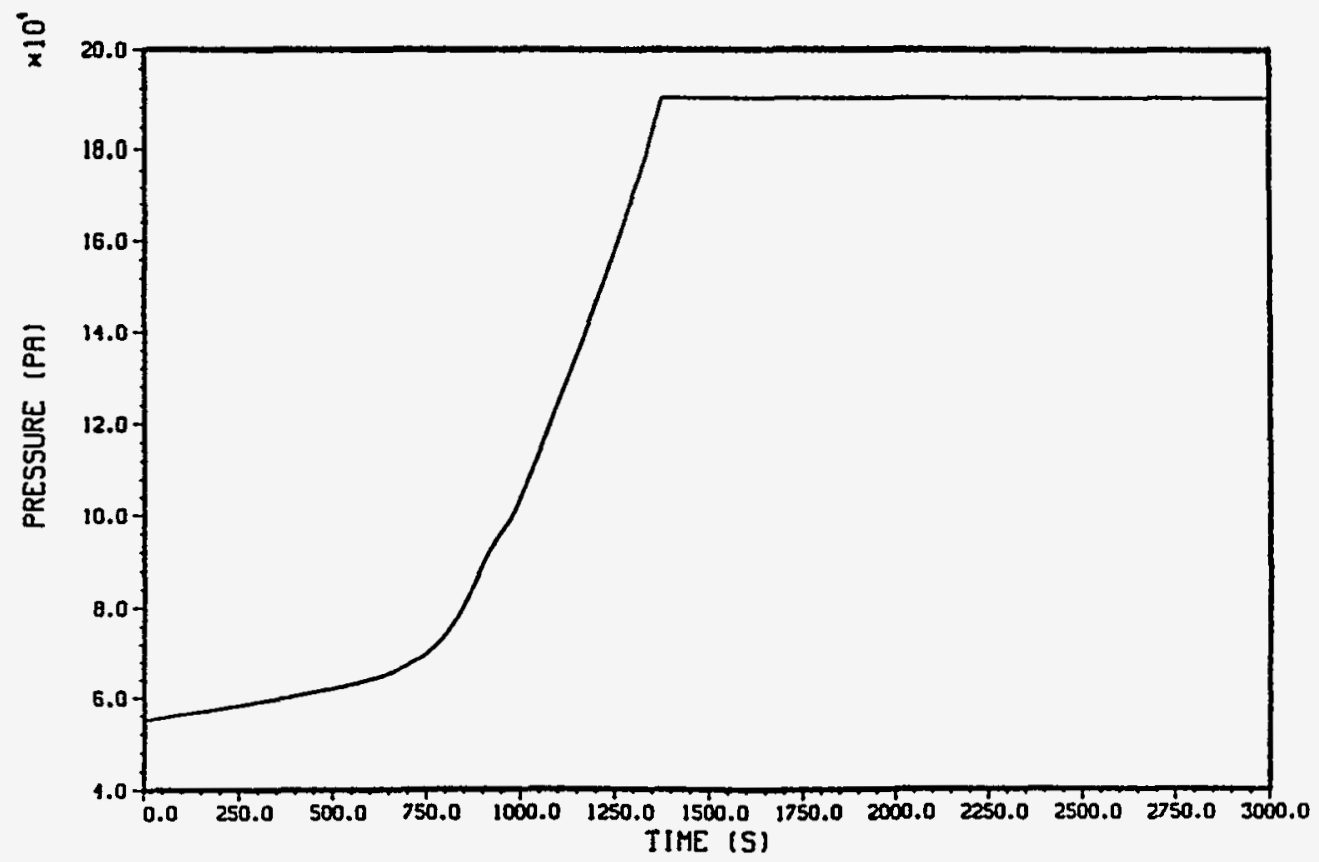

Figure 2.15 System Pressure Response for the Abnormal Startup Case 


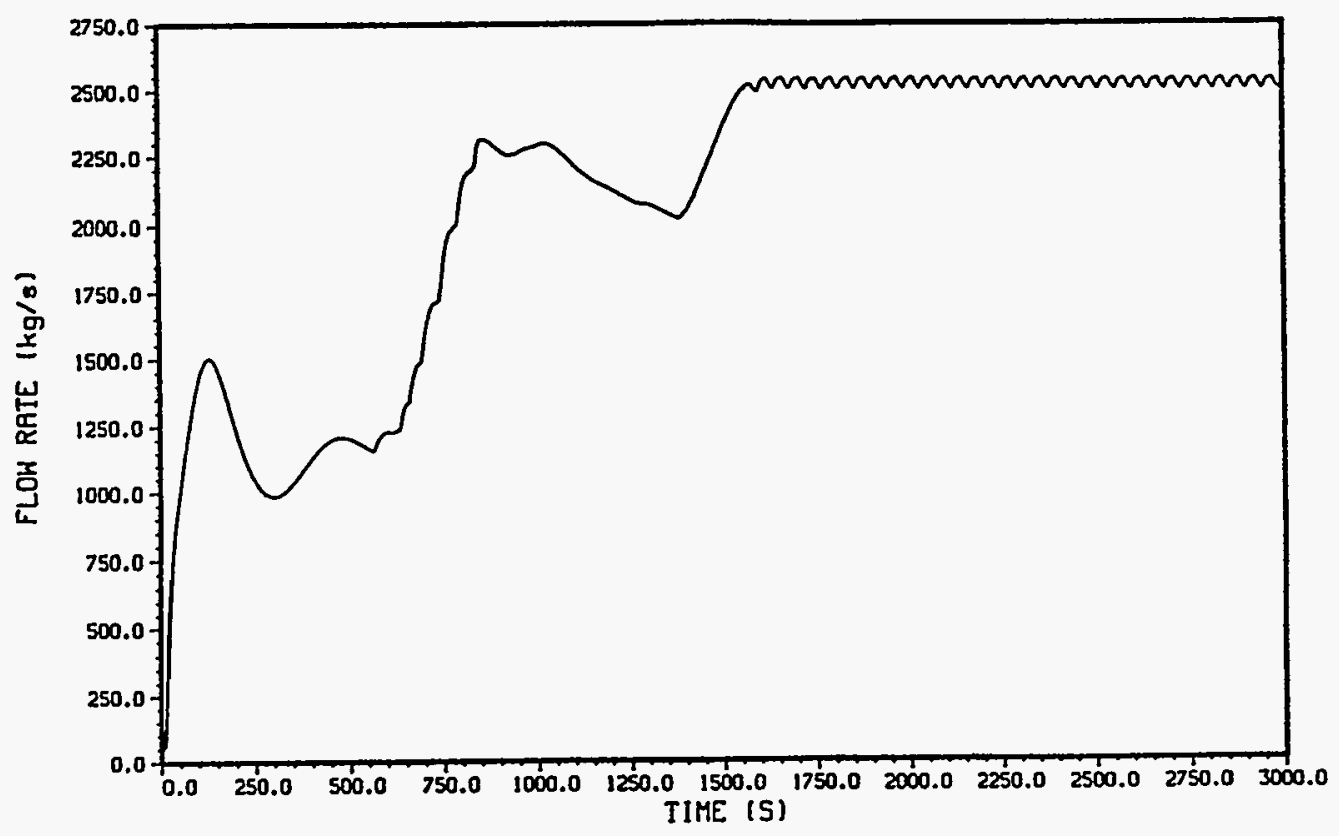

Figure 2.16 Total Core Inlet Flow Response for the Abnormal Startup Case

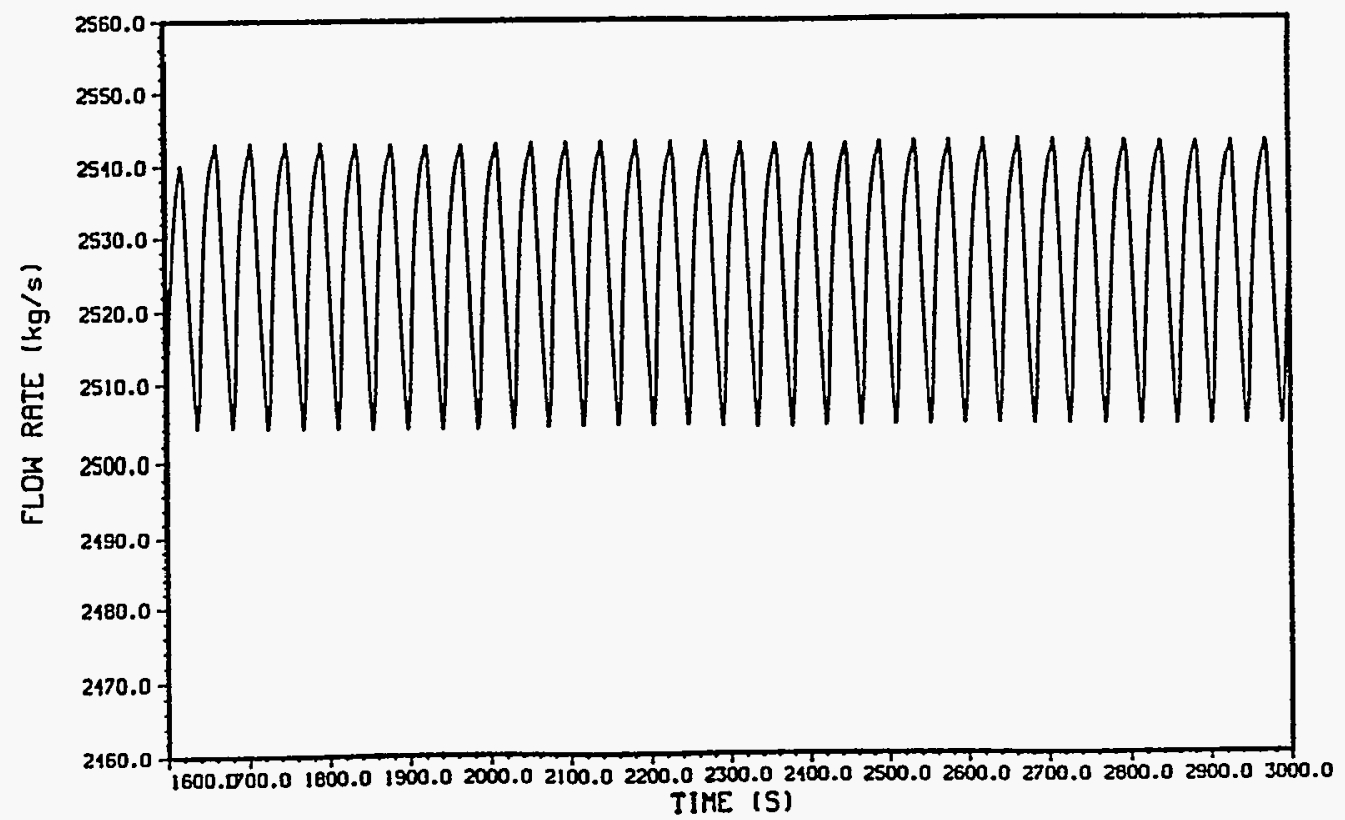

Figure 2.17 Zoomed Core Flow Oscillations for the Abnormal Startup Case 
The SBWR startup transient begins from a low-power, low-pressure, and low-flow condition. While the steam dome is at about 8 psia and saturated, most of the core is in subcooled condition. The core power and pressure are increased by pulling the control rods. Several component systems as described in the previous section are required to control the pressure and level. The pressure vessel conditions change during this transient. A review of the start-up procedure and the course of transients as simulated by GE through TRACG and by BNL with RAMONA-4B, indicated that the transient can be partitioned into four distinct phases.

Table 3.1 illustrates the startup procedure and four phases of the transient, referred to as Phase I, II, III, and IV, respectively. In this table, the first row indicates the phase of the transient, the second row is the GE's startup steps and the third row describes the dominant processes. The fifth and sixth lines indicate injection flows. The seventh line describes downcomer water level position. The last line indicates the possibility and the type of oscillations. In the next subsections, these phases and the transitions between them will be described and in the subsequent sections PIRT will be described for each phase along with the figure of merit for ranking the phenomena.

\subsection{Phases of SBWR Startup Transient}

The four phases of the SBWR startup transient are illustrated in Figures 3.1, 3.2 and 3.3.

\subsubsection{Subcooled Core Heat-up}

The first phase is called Subcooled Heat-up Phase (or Phase I). It includes first three steps of the GE's startup procedure (Section 2.1). During this phase, the fluid in the vessel is subcooled and there is no vapor generation. This phase ends with onset of net vapor generation. In the first part of this phase the coolant is heated up to $80^{\circ} \mathrm{C}$ by either core decay heat or electric heaters or the RWCU/SDC systems. The next step is to dearate the coolant by connecting the RPV to the condenser and the low pressure in the condenser will pull the dissolved gases until the dissolved gas concentration in the dome is within a specified limit. The last step in this phase is to increase core power by withdrawing the control rods. The increase in the core power leads to density change in the core and beginning of natural circulation in the RPV. During this phase, the initial injection to RPV consists of CRD flow and subsequent injection includes RWCU/SDC flow.

Due to the hydrostatic head, there is an axial variation of pressure along the core height of $2.74 \mathrm{~m}$ and the chimney, and the saturation temperature distribution follows correspondingly. During the early part of Phase I, the pressure at the dome does not change significantly and hence the axial profile of saturation temperature remain unchanged. Within this period, single-phase natural circulation flow prevails in the core until subcooled vapor generation begins. The saturation temperature is the lowest at the top of the chimney. However, in the core the lowest saturation temperature is at the top, and the liquid temperature is the highest in this region; therefore, subcooled vapor generation begins at this location. During the startup process, the boundary of subcooled vapor generation moves towards the core entrance. However, subcooled condition within the core is unable to sustain the vapor generation, which results in condensation of the bubbles after detachment. During this process, fluid temperature within the core increases and the flow is enhanced. Onset of Net Vapor Generation (NVG) is associated with sustained bubble concentration in the channels and a consequent increase in buoyancy induced flow.

NVG separates Phases I and II as shown in Table 3.1 and Figure 2.5.

\subsubsection{Subcooled Chimney Phase}

The saturation temperature in the chimney varies along its height of 10.58 meters, with the lowest being at the top. During Phases $I$ and II, most of the coolant within the chimney remains subcooled. Migration of the vapor bubbles 
Table 3.1 Summary of SBWR Startup Transient Phases

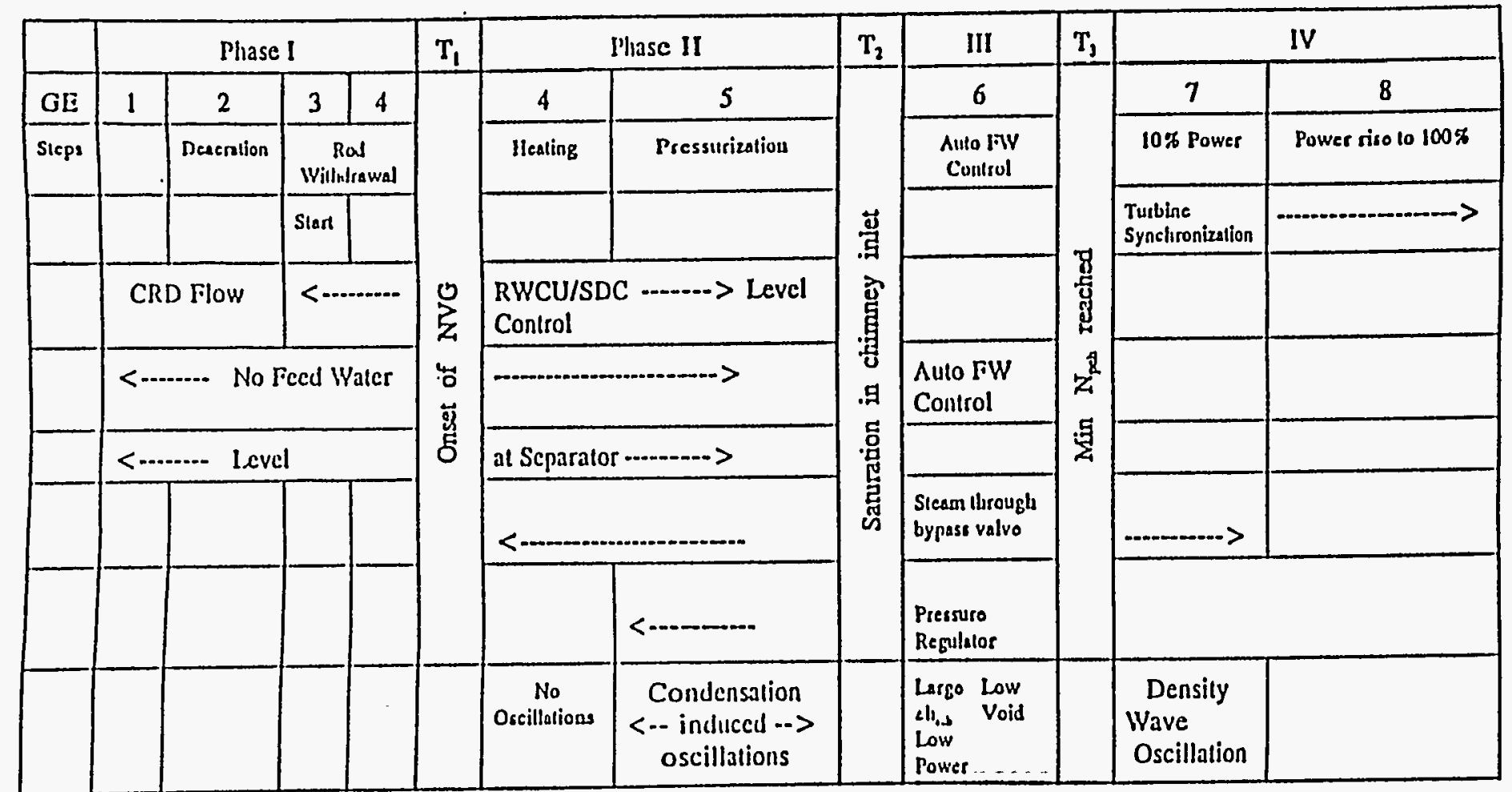

Powver $\%<2 \%$

Flow $\%<12 \%$

$T_{1}=$ Onset of NVG

$T_{2}=$ Saturation in Chinıney Inlet

$\mathrm{T}_{3}=$ Min $\mathrm{N}_{\alpha \mathrm{h}}$ reached or Possibility of Density Wave 


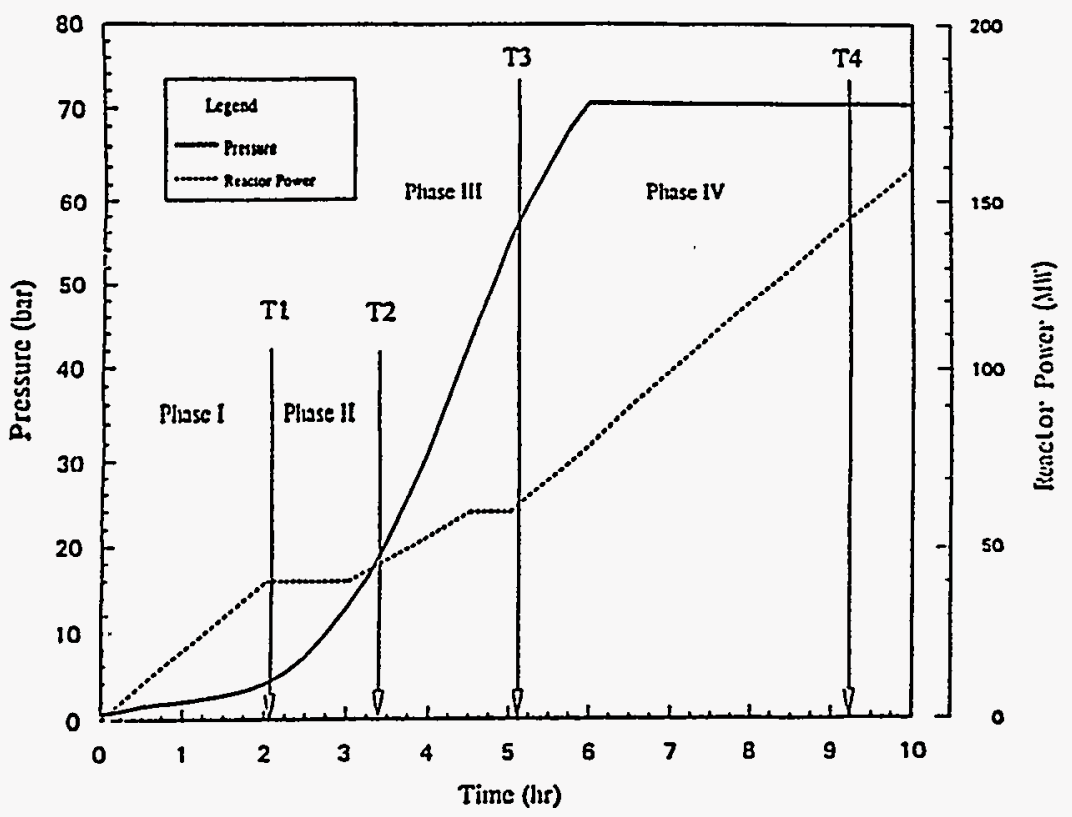

Figure 3.1 Pressure and Power Characterization of SBWR Startup Phases

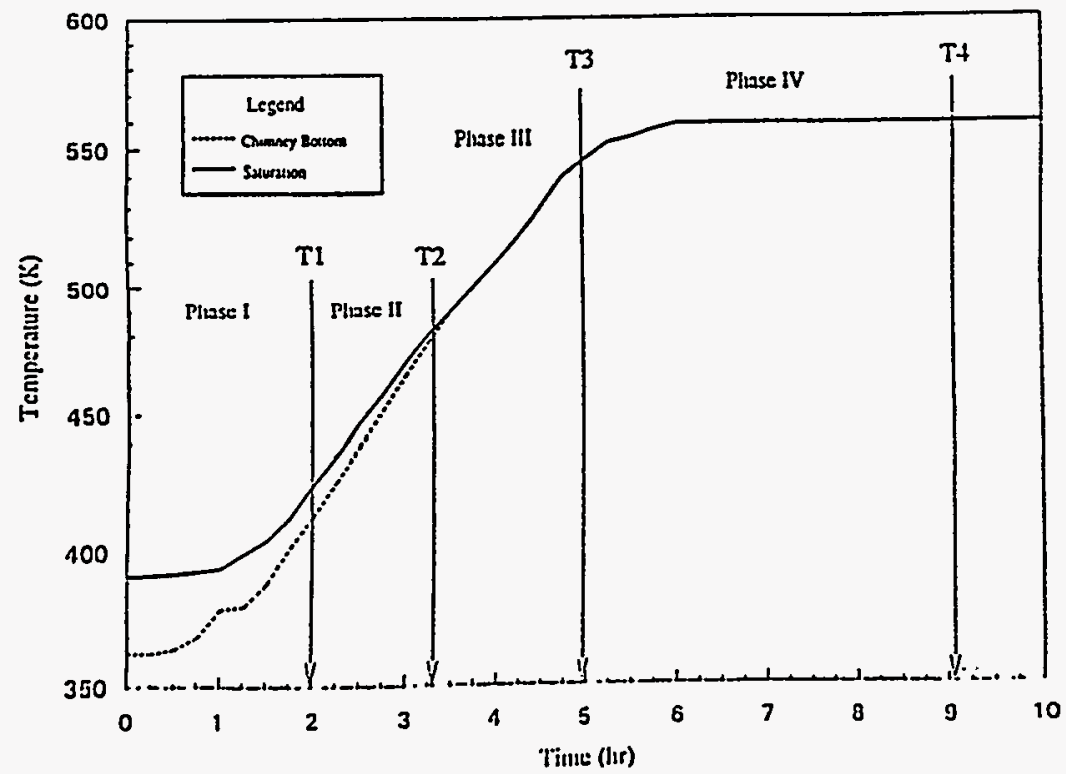

Figure 3.2 Coolant Temperature Characterization of SBWR Startup Phases 


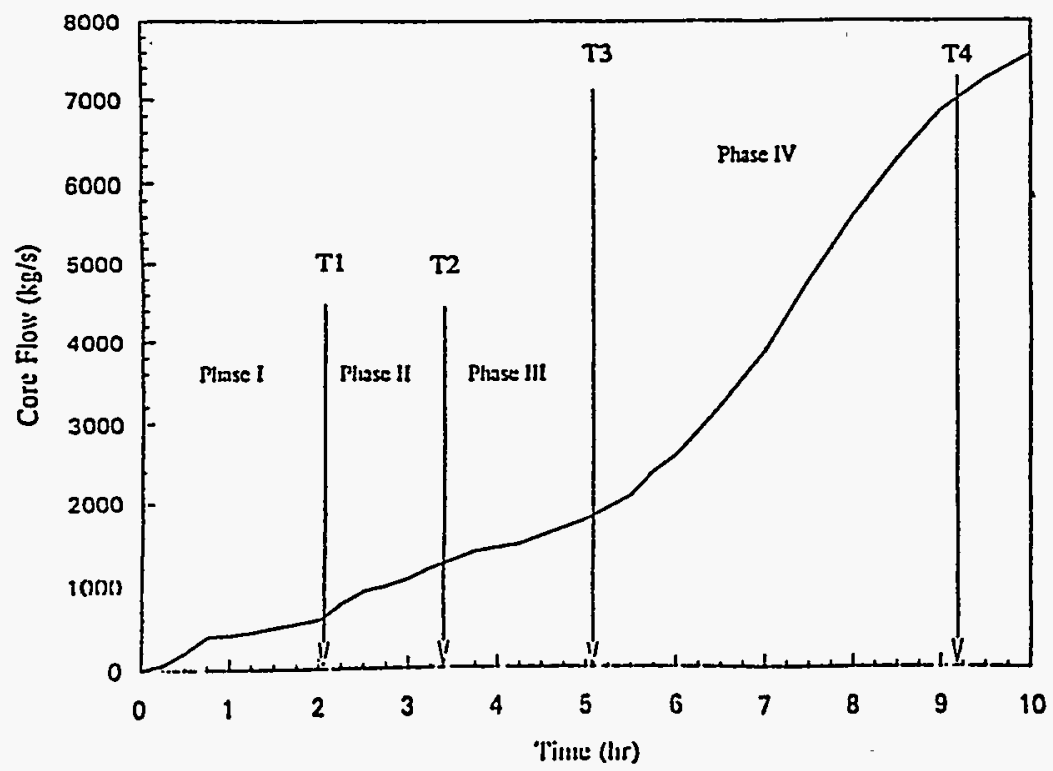

Figure 3.3 Core Flow Channel of SBWR Start-Up Phases 


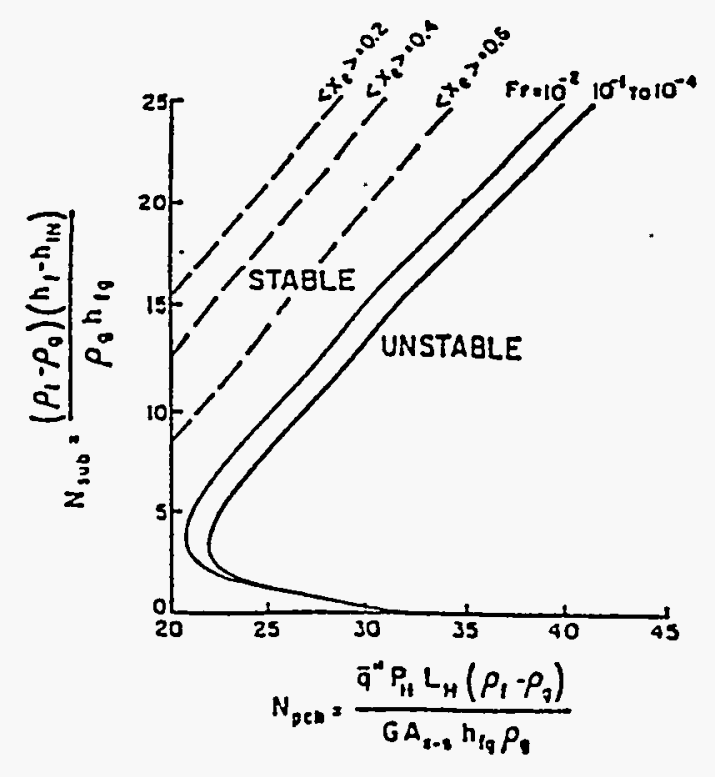

Figure 3.4a Typical BWR/4 Stability Map $\left(K_{l n}=27.8, K_{e x i t}=0.14\right)$ (Ref. Lahey \& Moody, 1993, Fig. 7-10)

Conservative Stability Criterion for Density Wave

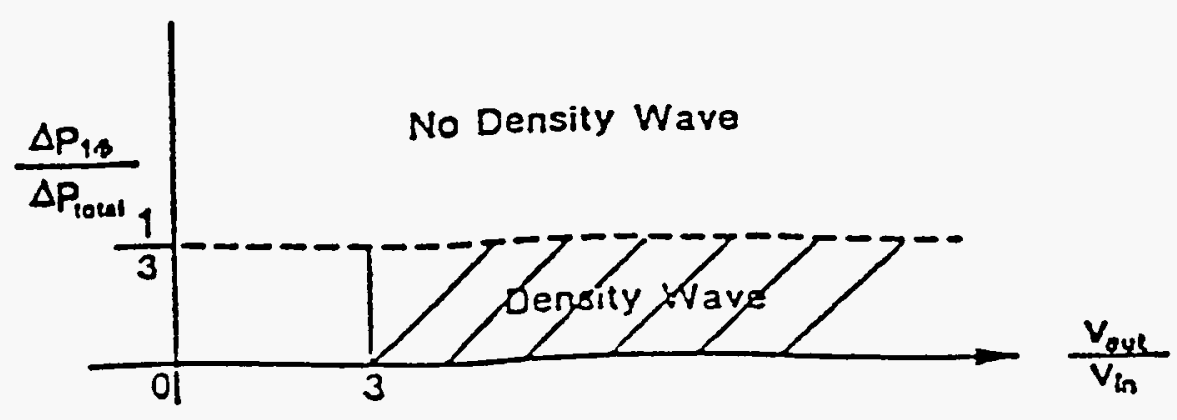

Figure 3.4b Conservative Stability Criterion for Density Wave 
to the chimney results in condensation in the subcooled fluid and a consequent heating of the coolant. This process of heat transfer from the core to the fluid in the chimney, through bubble condensation, continues and the chimney reaches saturation at different axial levels. Figures 2.4 and 3.2 show the temperature rise in the chimney bottom.

The saturation condition at the inlet of chimney is identified as the transition from Phase II to Phase III. This phase lies between times $T_{1}$ and $T_{2}$.

\subsubsection{Saturated Chimney Phase}

During this phase, the power increase continues with the withdrawal of the control rods. There is flashing in the chimney which will lead to an increase in buoyancy forces and natural circulation flow. There is condensation taking place in the chimney fluid. The level is controlled by the feedwater controller. The steam flow is bypassed to the condenser. The reactor is susceptible to a loop type of oscillation. This phase is characterized with large subcooling, low power and low voids in the core.

This phase ends when the reactor becomes susceptible to density waves. There are two possible ways to find this transition, either by stability map [Lahey, 1976], shown in Figure 3.4a, or by a simple criteria proposed by Prof. Griffith, as shown in Figure 3.4b. In Figure 3.4a, the abscissa represents Phase Change Number (Zuber Number), $\mathrm{N}_{\text {pch }}$ which is proportional to core inlet subcooling. As the figure indicates, there is a minimum $\mathrm{N}_{\text {pch }}$ below which the reactor is stable with respect to density waves. Based on this brief description, it is concluded that the transition between Phase III and Phase IV can be defined in terms of the minimum $\mathrm{N}_{\mathrm{pch}}$.

In Figure 3.4b, the abscissa represents a ration core outlet velocity to core inlet velocity and the ordinate represents a ratio of single phase pressure drop to total pressure drop in the heated channel. Griffith's proposed criteria states that when the two phase pressure exceeds $2 \%$ fraction of total pressure drop, the core becomes unstable and the density wave can occur.

\subsubsection{Power Ascension Phase}

This is the last phase during which reactor power is increased to full power by withdrawing the control rods. The level is maintained by feedwater flow controller. The core flow and system pressure, both increase. The pressure drops at the core inlet, at the core exit, and kinetic feedback play important roles in determining the possibility of density waves.

\subsection{Figure of Merit or Assessment Criterion}

The assessment of the SBWR startup stability is based on the Minimum Critical Power Ratio (MCPR) as the figure of merit. This is appropriate because the thermal-hydraulic instability usually induces flow and power oscillations, which tend to reduce the MCPR if the amplitude of the oscillations is substantial. Large power oscillations can lead to post-CHF conditions if the oscillations continue for a long period of time. The post-CHF condition is closely related to the clad wall temperature, void fraction, and flow rate, all of which will affect the MCPR. Therefore, by using MCPR as the figure of merit (or assessment criterion), the key thermal-hydraulic parameters are adequately covered.

More specific figures of merit are related to the amplitude of oscillations. The amplitude of oscillation has implication to safety and can be used directly as a figure of merit. The other possible candidate is the decay ratio, widely used in the stability analysis in frequency domain. The decay ratio is the ratio of consecutive power oscillation amplitudes. Thus, a decay ratio of unity indicates a sustained oscillation, while a decay ratio of greater than unity 
indicates a diverging oscillation, which can be troublesome if not suppressed. However, the decay ratio alone may not necessarily indicate a post-CHF condition.

\subsection{PIRT for SBWR Startup Stability}

A team of cognizant engineers (see Appendix B) was assembled at BNL to develop the Phenomena Identification and Ranking Table (PIRT) for start-up transient. The first step in the process was to identify the start up procedure for SBWR as described in Section 2.0. The second step was to follow the transient from different analyses and experiments as described in Section 3.1. The transient was further divided into four phases based on special phenomena or equipment, etc. These are described in Section 3.2. The BNL team then identified the phenomena for the four phases. A set of figures of merit was also identified. The phenomena in each phase were ranked based on their impact on the figure of merit. A total of 7 meetings were held with a BNL team, as listed in Appendix C. A preliminary PIRT was produced. A final meeting was held with the BNL team and outside participants, listed in Appendix $B$, to review the PIRT and a modified PIRT is presented here. The minutes of the meeting are given in Appendix D.

The preliminary results of PIRT process is described in four tables for four phases in Appendix F. Each PIRT consists of components and their geometry description, phenomena and their descriptions, ranking and ranking rationales. The detailed description of the components and phenomena are given in Appendix E. The SBWR plant has been divided into 10 components as described in Table E.1. The team identified 33 distinct phenomena which have been described in Table E.2.

The first column in PIRT in Appendix F is the list of components of SBWR. The second column lists the geometry of the components and this information is useful in determining the need for relevant data. The third column lists the phenomena and the fourth column lists the location in where the phenomena is described. The fifth column lists the ranking and the sixth column explains the rationale behind the ranking. The Phase I (Subcooled Core Heat-up) has 28 applicable phenomena and ranking with 17 ranked low, 6 ranked medium and 5 ranked high. The Phase II (Subcooled Chimney) has 39 ranked phenomena with 18 ranked low, 13 ranked medium and 8 ranked high. The Phase III (Saturated Chimney) has 47 ranked phenomena with 22 ranked low, 10 ranked medium and 15 ranked high. The last phase, Phase IV, (Power Ascension) has 46 ranked phenomena with 16 ranked low, 12 ranked medium and 18 ranked high. Based on this survey, it is concluded that the last two phases have many high-ranked phenomena and will influence code applicability. 


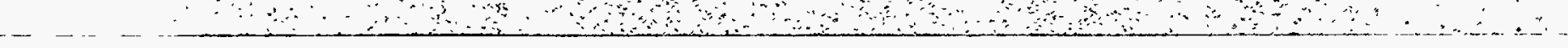




\subsection{High Ranking Phenomena}

In order to highlight the important aspect of the PIRTs, the high ranking phenomena for each of the four phases are recompiled and summarized in Tables 4.1 through 4.4. The Table 4.5 summarizes all the ranking in one place for all four phases.

The 3-D kinetics and associated feedbacks, stored energy and the single phase pressure drop in the core were all rated high for all four phases. The phenomena related to separator/dryer components and level motion in the steam dome were also rated high for all the phases. The control system also appears in all four phases but the specific control system required in a phase, vary from phase to phase. The first two phases need level control through RWCU system, while the third and fourth phases require level control through feedwater system. The last phase also has an active pressure regulator. The phenomena related to the chimney component play active roles in the last three phases and phenomena such as evaporation, subcooled boiling and two phase pressure drop become important.

\subsection{Validation of PIRT}

PIRT presented in this report is based on judgement of the participating engineers, the analysis of the start-up transients at BNL with RAMONA-4B and GE's analysis with TRACG, and some experiments. These experiments consist of laboratory scale test for geysering (Aritomi et al, 1990, 1993) and tests for loop wide instability at low pressure and low power (Wang et al, 1994). While the PIRT presented here can be used as the basis of code development, code assessment and planning for tests, it should be treated as a living document which will be revised as new information becomes available. The revision will take place in the identification of phenomena and their ranking. The existence of new phenomena can only be obtained from tests. The ranking of the identified phenomena can be validated in three ways.

The first way is to perform sensitivity calculations by varying the parameters in the models for the high and medium ranked phenomena. The parameters are varied by the one standard deviation in their uncertainty and the effect on the figure of merits, such as MCPR, containment pressure, and suppression pool temperature, is estimated. The high ranked phenomena will have a larger effect than the medium ranked phenomena. The second method is to develop formulations for predicting the figure of merits and to non-dimensionalize the equations with characteristic parameters. The resulting nondimensional groups will correspond to the phenomena identified in the PIRT. The values of these nondimensional groups are the measure of importance of various phenomena. All the phenomena can be ranked with this method and provide a basis for relative ranks. The third approach is to conduct tests in a scaled integral facility by varying the parameters affecting the figures of merit. This approach while not as general as the sensitivity calculations, could be more reliable. 
Table 4.1 High Ranking Phenomena for Phase I: Subcooled Ileatup (0st $\leq \tau$ )

\begin{tabular}{|c|c|c|c|c|c|}
\hline \multicolumn{4}{|c|}{ 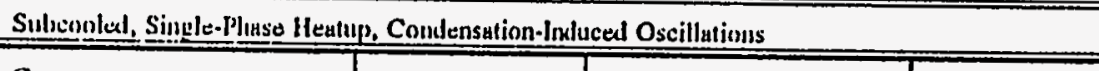 } & \multicolumn{2}{|c|}{ Event Pliase: Pliase 1} \\
\hline Compxment & $\begin{array}{l}\text { Type of } \\
\text { Geametry }\end{array}$ & Plenomenon & $\begin{array}{l}\text { Plenomintnon } \\
\text { Description } \\
\end{array}$ & Rank & Ranking Rationale \\
\hline \multirow{6}{*}{$\begin{array}{l}\text { Reactor Core } \\
\text { C7 }\end{array}$} & \multirow[t]{6}{*}{ Vertical Cleunuels } & $\begin{array}{l}\text { Roud Wortl and Rod } \\
\text { Pusition }\end{array}$ & P8 & H & $\begin{array}{l}\text { Coutrol rods are willderawn to obtain control power } \\
\text { ascension }\end{array}$ \\
\hline & & 3D Kinetics & P9 & H & $\begin{array}{l}\text { Power peaking may be ligh due to control rod } \\
\text { willudrawal jallem }\end{array}$ \\
\hline & & Doppler Feullack & P11 & H & $\begin{array}{l}\text { The main fealback compensating rod worth for } \\
\text { crificality }\end{array}$ \\
\hline & & Moderalur Feexllack & $\mathrm{P} 12$ & H & $\begin{array}{l}\text { Moderutur (etmytrature feedback helps compensating the } \\
\text { rixd woonh for criticality }\end{array}$ \\
\hline & & Fiuel Stural Funergy & $P 2$ & H & Main comtributor to coolant temp. increaso \\
\hline & & 1.中 Pressura Drop & P5 & HI & The comprolling faclor for core flow \\
\hline 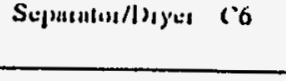 & $\begin{array}{l}\text { Swinl } \\
\text { Vantiss/Pijes }\end{array}$ & Pressuie Drop & P17 & H & Main contritutur to ex-coro pressuro drop \\
\hline Sicum Bume cre & Heani-Splhero & Level Mution & PI & H & Level mution in domo, contruls cora flow \\
\hline Comiroul Systemis cio & Wites, Circuils & $\begin{array}{l}\text { RWCU System Level } \\
\text { Cominol }\end{array}$ & P33 & H & $\begin{array}{l}\text { Level is controlloul by the renctor water cleanup unit } \\
\text { (RWCII) }\end{array}$ \\
\hline
\end{tabular}


Table 4.2 High Ranking Phenomena for Phase 1I: Subcooled Chimney $(\tau, s t \leq \tau)$

\begin{tabular}{|c|c|c|c|c|c|}
\hline \multicolumn{4}{|c|}{ 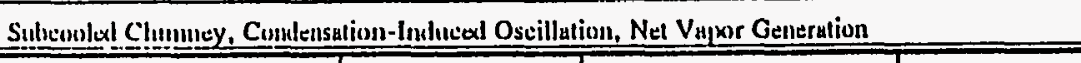 } & \multicolumn{2}{|c|}{ Event Pliase: Plinso II } \\
\hline Comproment & $\begin{array}{l}\text { Tylo of } \\
\text { Geometry } \\
\end{array}$ & Plenomenon & $\begin{array}{l}\text { Phenonienon } \\
\text { Descripxion } \\
\end{array}$ & Runk & Rauking Rutionulo \\
\hline \multirow[t]{10}{*}{ Realctur Cure } & \multirow[t]{10}{*}{ Verticul Cluwusels } & $\begin{array}{l}\text { Roul Worlt und } \\
\text { Rexl Position! }\end{array}$ & P8 & H & Control rods are withdrawn to raiso power \\
\hline & & 3D Kineties & P9 & H & .High peuhing at low power, possiblo oscill. \\
\hline & & Doppler Feallback & PII & H & $\begin{array}{l}\text { The main feallock compensating rod worth for } \\
\text { criticality }\end{array}$ \\
\hline & & Moderalur licallaack & P12 & $\mathbf{H}$ & $\begin{array}{l}\text { Moderutur tenixeruturo feulback lwelps conipensaling tho } \\
\text { rol worth for criticality }\end{array}$ \\
\hline & & Sinicture Storeal Eutergy & $\mathbf{P 2}$ & $\mathbf{H}$ & $\begin{array}{l}\text { Because of oscillations theso belaave like teruporary } \\
\text { storages of lieul. Temperaluro of the structure is lighl. }\end{array}$ \\
\hline & & Fuct Slutad Enurby & $\mathbf{P} 2$ & u & $\begin{array}{l}\text { Becauso of oscillations these beluve liko temporary } \\
\text { sturages of heta. Temperaturo of tho fuel is significantly } \\
\text { highter than the fluid }\end{array}$ \\
\hline & & Lleut Tumsfor & P15 & H & Impracts fluid temuperaturo aud vupor generation rulo \\
\hline & & 1-中 Pressure Drue & ps & H & The combrolling factor for coro flow \\
\hline & & 2- $\phi$ Pressura Drop & P17 & H & Inupecs coro flow and stubility \\
\hline & & Sulacoudal Heiling & P18 & II & Main mectumism for boiling \\
\hline $\begin{array}{l}\text { Clinusy and Upher Pletum } \\
\text { is }\end{array}$ & Pijre, Sinicturo & Conklensution & P22 & $\mathbf{H}$ & Inpucts geysering \\
\hline Scjputulor/l)iyor ('6 & $\begin{array}{l}\text { Swirl } \\
\text { Vutses/Pipes }\end{array}$ & Pressure Drop & P17 & U & Iniprats flow rato ( conipure with the care) \\
\hline Slenm Dume C8 & Ilemi-Spliero & Level Muliun & Pl & H & Level swell due to heating \& vapor gener. \\
\hline Control Sysicuss CiO & Wires, Circuils & $\begin{array}{l}\text { RWCU Systein Level } \\
\text { Conlenl }\end{array}$ & P33 & II & $\begin{array}{l}\text { RWCU is active for level coutrol and diclates } \\
\text { suldenaliene }\end{array}$ \\
\hline
\end{tabular}


Table 4.3 Figh Ranking Phenomena for Phase III: Saturated Chimney $\left(\tau, \leq t \leq \tau_{3}\right)$

\begin{tabular}{|c|c|c|c|c|c|}
\hline \multicolumn{4}{|c|}{ Silluraled Climuney, Buoyuncy-Driven Oscillations } & \multicolumn{2}{|c|}{ Event Phase: Pliase III } \\
\hline Component & Type of Geometry & Phenomenun & $\begin{array}{l}\text { Phenomenon } \\
\text { Description }\end{array}$ & Rank & Ranking Rationale \\
\hline Doumlemer & Anunulus & Feedwater lnjection & P4 & H & Dictules subconling and reactivity \\
\hline Reactor Core & \multirow[t]{10}{*}{ Vertical Channels } & $\begin{array}{l}\text { Rod Wouth und } \\
\text { Rod Positions }\end{array}$ & P8 & H & $\begin{array}{l}\text { Coutrol rods aro willsdrawn to raiso power and maintuin } \\
\text { criticulity }\end{array}$ \\
\hline \multirow[t]{9}{*}{ c7 } & & 3D Kinetics & P9 & H & Puwer peating is high at moderate power level \\
\hline & & Vojd lieallunck & PlO & H & Dominum feallack because of ligh void \\
\hline & & Siniclure Stored Energy & $\mathbf{M}$ & H & $\begin{array}{l}\text { Because of oscillations these belunve liko temporary } \\
\text { storages of lieut. Temperature of the structure is ligh. }\end{array}$ \\
\hline & & Fuel Storal Energy & $\mathbf{p}$ & H & $\begin{array}{l}\text { Becuuso of oscillations theso beliave liko temporury } \\
\text { storages of heat. Temperuturo of the fuel is significantly } \\
\text { higher than the fluid }\end{array}$ \\
\hline & & Gup) Conductuntco & P14 & $\boldsymbol{H}$ & $\begin{array}{l}\text { Inpocts fuel time constant and inportant during } \\
\text { oscillations }\end{array}$ \\
\hline & & Heat Trunsfor & P15 & H & Impacts flinid temperature and void content \\
\hline & & 1. $\phi$ Pressure Drup & PS & H & Impacts core flow arud stability \\
\hline & & 2. $\phi$ Pressure Drop & P17 & H & Inupacts core flow ascl stulility \\
\hline & & $\begin{array}{l}\text { Suldrosular Builing } \\
\text { /Evajorsution }\end{array}$ & P18 & H & lınpacts vapkrr genteration and oscillations \\
\hline \multirow[t]{2}{*}{ 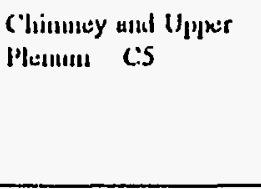 } & \multirow[t]{2}{*}{ Pije, Stuncture } & Plase Separation & 820 & H & Controls flow via buoyancy \\
\hline & & Condensation & $\mathbf{P 2 2}$ & H & 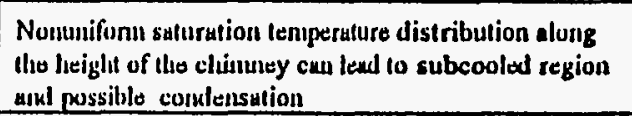 \\
\hline \multirow[t]{2}{*}{ Sųpatulus/1):yer $C 6$} & Swirl Vanles & Pressuro Drop! & P17 & H & luppacts flow and oscillations \\
\hline & Pijx:s & Sejurator lueitia I/A & $\mathbf{P 2 3}$ & II & Largo impealumico to oscillutions \\
\hline
\end{tabular}




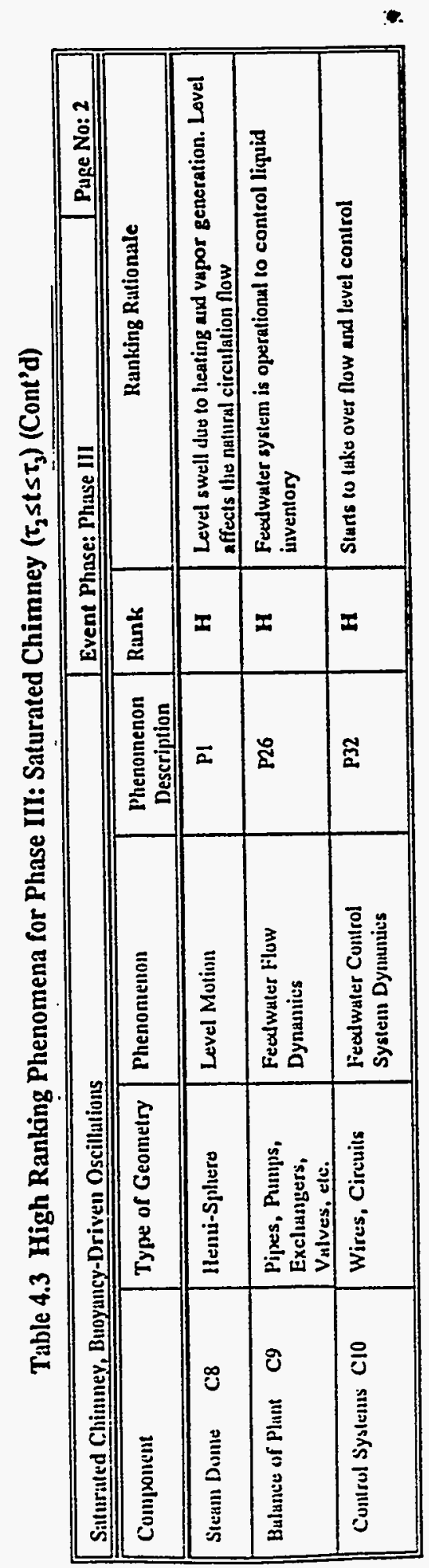


Tahle 4.4 High Ranking Phenomena for Phase IV: Power Ascension 10 Operating Condition $\left(\tau_{3} \leq t \leq \tau_{3}\right)$

\begin{tabular}{|c|c|c|c|c|c|}
\hline \multicolumn{4}{|c|}{ linll Boiling, Densily Wuve Oscillutions, lligh Power, Flow and Pressure } & \multicolumn{2}{|c|}{ Event Pliuse: Pliuse IV } \\
\hline Connј)onent & $\begin{array}{l}\text { Typo of } \\
\text { Geometry }\end{array}$ & Phenonentun & $\begin{array}{l}\text { Phesoinenon } \\
\text { Description }\end{array}$ & Rauk & Runking Rutionulo \\
\hline \multirow[t]{2}{*}{ Duwnicomer } & \multirow[t]{2}{*}{ Asusulus } & Ftusluing & P3 & $\mathbf{H}$ & $\begin{array}{l}\text { Flusling duo to oscillution can lead to chango in core inlet } \\
\text { flow }\end{array}$ \\
\hline & & Feadwaler lijection & P4 & H & $\begin{array}{l}\text { Muin sourco of fluid which impacts coro flow and } \\
\text { sulicooling }\end{array}$ \\
\hline \multirow[t]{10}{*}{ Recactur Core } & \multirow[t]{10}{*}{ Vertical Chunulels } & $\begin{array}{l}\text { Rod Wortls und } \\
\text { Roxl Position }\end{array}$ & P8 & $\mathbf{H}$ & $\begin{array}{l}\text { Control rods aro wiltulrawn to raiso power and numintain } \\
\text { criticulity }\end{array}$ \\
\hline & & 3D Kineties & P9 & $\mathbf{H}$ & High Peuking due to Rod Removal \\
\hline & & Void Feallogick & P10 & H & Dominums feallsack becauso of high void fraction \\
\hline & & Stnucture Stural Energy & P2 & $\mathbf{H}$ & $\begin{array}{l}\text { Hecunse of oscillations these belave liko tenuporary } \\
\text { slorages of hest. Teimperature of the structuro is lighh. }\end{array}$ \\
\hline & & Fuel Sturad Energy & $\mathbf{P} 2$ & H & $\begin{array}{l}\text { Because of oscillations these behave liko temporary } \\
\text { storages of heal. Tenperaturo of the fuel is siguificuntly } \\
\text { liggher thun the fluid }\end{array}$ \\
\hline & & Gup C.unductance & P14 & H & Impacts fitel time constaut and oscillutions \\
\hline & & Heut Trumsfer & P15 & $H$ & Impacts fluid temperature euxd void consent \\
\hline & & 1-中 Pressillu Drup & P5 & H & Impacts coro flow and stubility \\
\hline & & 2.中 Pressine Drope & P17 & $\|$ & Inipacils coro llow usul stulijlity \\
\hline & & $\begin{array}{l}\text { Sulrcuolul Boiling } \\
\text { /Evapuratation }\end{array}$ & P18 & H & lnupacts vapor genteration and oscillations \\
\hline 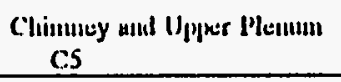 & Pije, Sinicturo & Plasse Situduratiou & P20 & и & $\begin{array}{l}\text { Controls fluw anul buoyuncy dus to significand rolutive } \\
\text { velocity between liguid and vapor }\end{array}$ \\
\hline \multirow[t]{2}{*}{ Sifparalor/Diyer. C6 } & \multirow[t]{2}{*}{$\begin{array}{l}\text { Swirl } \\
\text { Vants/Pipes }\end{array}$} & Pressure Drop & P17 & $\mathbf{H}$ & Impracts flow and stability \\
\hline & & Sejarator Inertix $\nu A$ & $\mathbf{P 2 3}$ & H & Lurge inneodance to oscillations \\
\hline
\end{tabular}


Table 4.4 High Ranking Phenomena for Phase IV: Power Ascension to Operating Condition $\left(\tau_{3} \leq t \leq \tau_{4}\right)($ Cont'd)

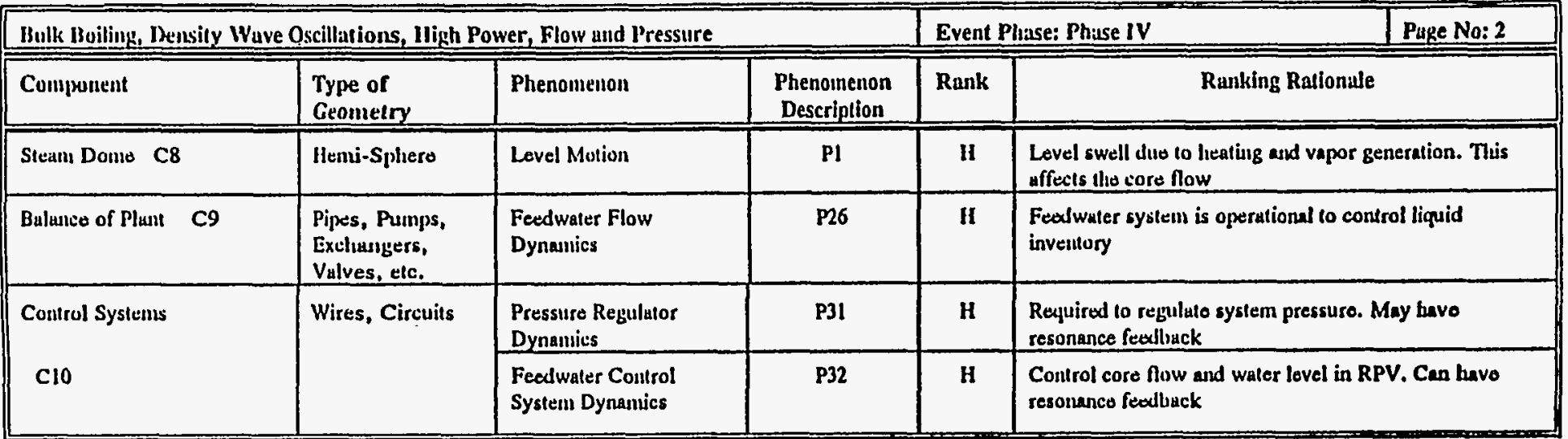




\section{Table 4.5 Composite PIRT}

\begin{tabular}{|c|c|c|c|c|c|c|c|}
\hline & & & & & & & Pago: 1 \\
\hline Compunentil & $\begin{array}{l}\text { Type of } \\
\text { Gemmelyy }\end{array}$ & Phenomenon and Description & $\begin{array}{l}\text { Pliaso I } \\
\text { Rasuking } \\
\end{array}$ & $\begin{array}{l}\text { Pliaso II } \\
\text { Runuking } \\
\end{array}$ & $\begin{array}{l}\text { Plusse III } \\
\text { Ranking: } \\
\end{array}$ & $\begin{array}{l}\text { Pluasu IV } \\
\text { Runking } \\
\end{array}$ & $\begin{array}{l}\text { Highest } \\
\text { Ranking } \\
\end{array}$ \\
\hline \multirow{4}{*}{$\begin{array}{l}\text { Duwnicomer } \\
\qquad \mathrm{Cl}\end{array}$} & & Heat Slubs/Storal Entergy, P2 & $L$ & $M$ & $\mathrm{M}$ & $\mathbf{M}$ & $\mathbf{M}$ \\
\hline & & Flashing, P3 & & L & $M$ & H & H \\
\hline & & Feodwaler Injection, P4 & & & 11 & H & H \\
\hline & & 1.中 Pressuro Drop. P5 & $\mathbf{L}$ & L & $L$ & $\mathbf{L}$ & $\mathbf{L}$ \\
\hline Lower Hleuแu & $\begin{array}{l}\text { Pijxo, Sinicturcllo } \\
\text { rizontul }\end{array}$ & Heat Slabs/Storad Energy, P2 & & $\mathbf{M}$ & $\mathbf{M}$ & $\mathbf{M}$ & $\mathbf{M}$ \\
\hline \multirow[t]{3}{*}{ C2 } & Vettical & CRD Flow linjection, P6 & $M$ & $\mathbf{M}$ & L & $\mathbf{L}$ & $\mathbf{M}$ \\
\hline & & Flashing, P3 & & & $L$ & $\mathbf{L}$ & $\mathbf{L}$ \\
\hline & & 1.中 Pressuro Drou, ps & $L$ & L & 1. & $\mathbf{L}$ & 1. \\
\hline Guido Tulve C3 & Pipo & Flow Leakiage/Refill, P7 & $\mathbf{M}$ & $\mathbf{M}$ & L. & $\mathbf{L}$ & $\mathbf{M}$ \\
\hline
\end{tabular}

Phase 1: Subcouled licatup (0stst)

Hiase II: Subiooled Clinaney $\left(t_{1} s t_{s} t_{2}\right)$

Prese IV: Power Asceusion to Opetaling Condition $(r, s t s t)$

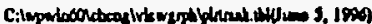


Table 4.5 Composite PIRT

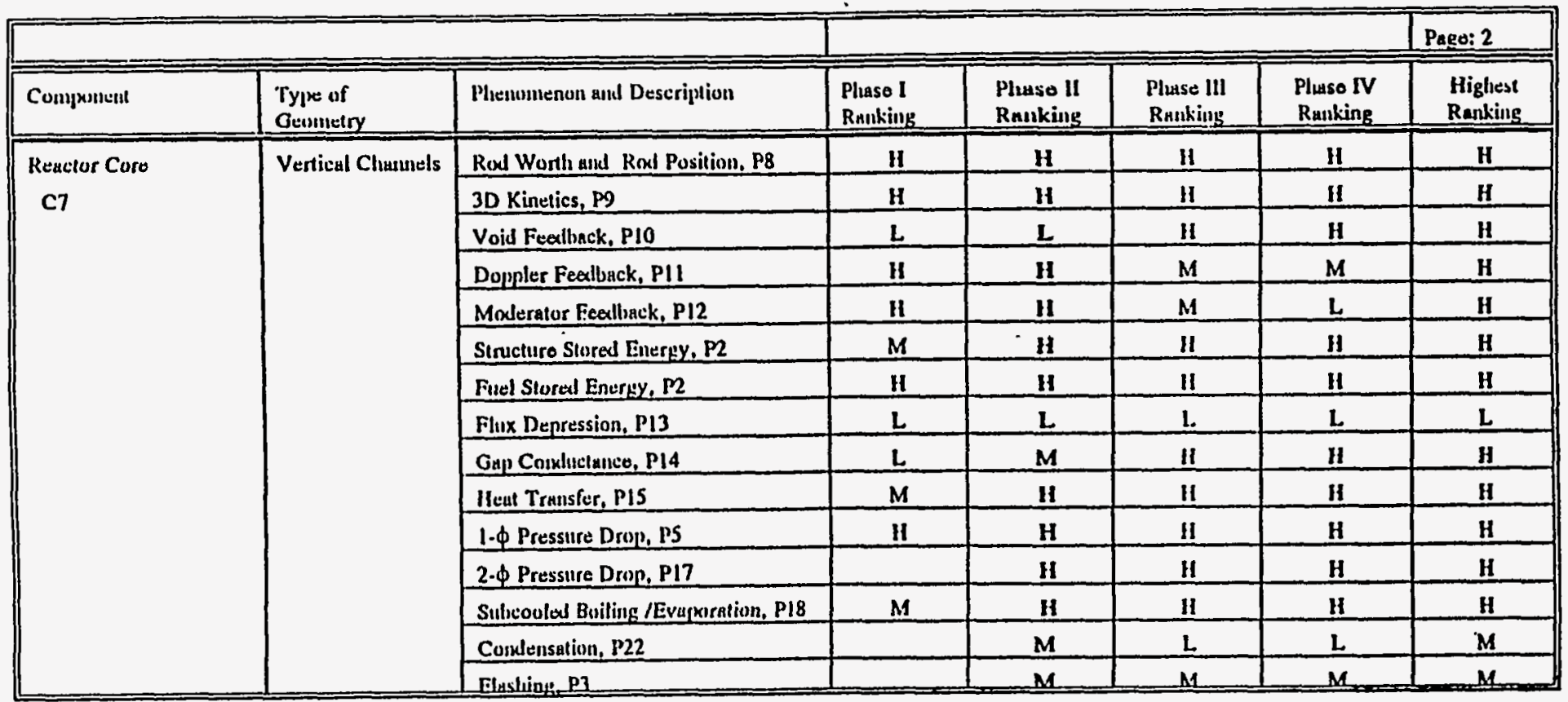

Plise l: Subcooled Ileatup (0sist)

Hiaze li: Subsouled Chimurey $\left(r_{1} s t s r_{2}\right)$

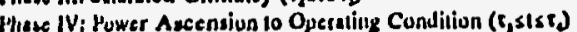

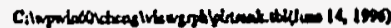


Table 4.5 Composite PIRT

\begin{tabular}{|c|c|c|c|c|c|c|c|}
\hline & & & & & & & Page: 3 \\
\hline Comiponent & $\begin{array}{l}\text { Type of } \\
\text { Geonuliry } \\
\end{array}$ & Phenomenon aud Description & $\begin{array}{l}\text { Pluaso I } \\
\text { Ranking } \\
\end{array}$ & $\begin{array}{l}\text { Phase II } \\
\text { Ranking } \\
\end{array}$ & $\begin{array}{l}\text { Pluse III } \\
\text { Runking } \\
\end{array}$ & $\begin{array}{l}\text { Plaso IV } \\
\text { Ranking } \\
\end{array}$ & $\begin{array}{l}\text { Highest } \\
\text { Rauking } \\
\end{array}$ \\
\hline \multirow[t]{2}{*}{ Coro Bypass } & \multirow[t]{2}{*}{ Vertical Clıannel } & Heat Slabs/Stored Energy, $\mathbf{2 2}$ & $\mathbf{M}$ & $\mathbf{M}$ & $\mathbf{M}$ & $\mathbf{M}$ & $\mathbf{M}$ \\
\hline & & Flasluing, P3 & & $\mathbf{L}$ & $L$ & $\mathbf{L}$ & $\mathbf{L}$ \\
\hline \multirow{3}{*}{$\begin{array}{l}\text { Chinney uaxl } U_{p p e r} \\
\text { Plenum } \\
\text { C5 }\end{array}$} & \multirow[t]{3}{*}{ Pijæo, Structure } & Pliaso Separation, P20 & & $\mathbf{L}$ & H & H & $\mathbf{H}$ \\
\hline & & $\begin{array}{l}\text { Flow Circulation and Distribution, } \\
\text { P21 }\end{array}$ & $\mathbf{L}$ & M & L & L & $\mathbf{M}$ \\
\hline & & Comuleisation, $\mathbf{P 2 2}$ & & H & $\mu$ & $\mathbf{M}$ & H \\
\hline \multirow{2}{*}{ Separator/Dryer } & \multirow{2}{*}{$\begin{array}{l}\text { Swirl Vuntes } \\
\text { Pijes }\end{array}$} & Carryunder, P24 & & & $\mathbf{L}$ & $\mathbf{L}$ & $\mathbf{L}$ \\
\hline & & Curryover, 125 & & & $\mathbf{L}$ & $\mathbf{L}$ & $\mathbf{L}$ \\
\hline
\end{tabular}

Mince I: Subecouled Ilealup (0sist)

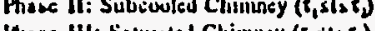

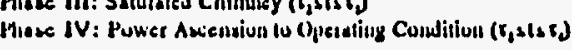


Tuble 4.5 Composite PIRT

\begin{tabular}{||l|l|l|l|c|c|c|c|}
\hline \hline & & & \\
\hline
\end{tabular}

Phese I: Subcooled lleatup (0sist)

Phese 1l: Subcooled Chimuncy ( $\left(r_{1}\right.$ sist)

thase IV: Power Ascension to Operating Condition ( $($, s/st)

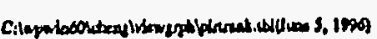


$\therefore$ 
1. Aritomi, M., Nakahashi, T., Chiang, J.H.,Wataru, M., and Mori, M.(1990), "Transient Behavior of Natural Circulation for Boiling Two Phase Flow (Experimental Results)," 6th Proc., Thermal Hydraulics, ANS Winter Annual Meeting, Washington D.C.

2. Aritomi, M.,Chiang, J.H., and Mori, M. (1993), "Geysering in Parallel Boiling Channels," Nuclear Engineering and Design, Vol 141, pp 111-121, North Holland Physics Publishing.

3. General Electric Nuclear Energy (1992), "SBWR Standard Safety Analysis Report," GET Report No.25A5113, Rev. A.

4. General Electric Nuclear Energy (1993), "TRACG Qualification Report," NEDE 32177P.

5. Haar, L., Gallagher, J.S., Kell, G.S. (1984), "NBS/NRC Steam Table, Thermodynamic and Transport Properties and Computer Programs for Vapor and Liquid States of Water, SI Units, Hemisphere, Washington, D.C.

6. Kim, H.T. (1993), "Geysering Instability Study for the SBWR," General Electric Nuclèar Energy, NEDO-32246.

7. Lahey, Jr, R.T., and Moody, F. (1993), "The Thermal-Hydraulics of a Boiling Water Nuclear Reactor", Second Edition, ANS.

8. Nissen, W.H.M., et al. (1992), "The Startup of the Dodewaard Natural Circulation BWR Experience," International Conf. on Design and Safety of Advanced Nuclear Power Plants, Vol. 3.

9. Rohatgi, U.S., Cheng, H.S., Khan, H.J., and Neymotin, L.Y. (1994), "RAMONA-4B: A Computer Code with Three Dimensional Neutron Kinetics, Models and Correlations" BNL-NUREG-52471, NUREG/ CR-6359.

10. Rohatgi, U.S., Cheng, H.S., Khan, H.J., Mallen, A.N., and Neymotin, L.Y., (1994) "RAMONA-4B: A Computer Code with Three Dimensional Neutron Kinetics, User's Manual, BNL-NUREG-52507, NUREG/CR-6485.

11. Wang, S.B., Wu, J.Y., Pan, C., and Lin, W.K. (1994), "Thermal Hydraulics Oscillations in a Low Pressure Two-Phase Natural Circulation Loop at Low Powers and High Inlet Subcoolings," 4th International Topical Meeting on Nuclear Thermal Hydraulics, Operations and Safety, Taipei, Taiwan.

12. Wulff, W., Cheng, H.S., Diamond, D.J., and Khatib-Rahbar, M. (1984), "A Description and Assessment of RAMONA-3B MOD.0 CYCLE4: A Computer Code with Three-Dimensional Neutron Kinetics for BWR System Transients," NUREG/CR-3664. 


\section{APPENDIX A}

(Intentionally left blank) 


\section{APPENDIX B LIST OF PARTICIPANTS}

Name

H. S. Cheng

H. J. Khan

U. S. Rohatgi

W. Wulff

D. Carlson

E.D. Kendrick

A.P. Ulses

J. March-Leuba

P. Griffith
Organization

BNL

BNL

BNL

BNL

USNRC

USNRC

USNRC

ORNL

M.I.T.
Telephone No.

(516)344-2611

(516)344-7028

(516)344-2475

(516)344-2608

(301)415-6777

(301)415-2891

(301)415-1194

(615)574-5571

(617)253-2248
Eax Number

(516)344-2613

(516)344-2613

(516)344-2613

(516)344-2613

(301)415-5160

(301)415-5160

(301)415-5160

(615)576-8380

$1-8$

$1-8$ 


\begin{tabular}{|c|c|c|c|c|}
\hline Meeting & Date & Time & Subjects & Attendeas \\
\hline 1 & $12-05-94$ & $10: 30-12: 00$ & $\begin{array}{l}\text { Reviewed GE's SBWR startup process. } \\
\text { Discussed potential problems in startup. } \\
\text { Discussed appropriate PIRT procedures. }\end{array}$ & BNL Team \\
\hline 2 & $12-22-94$ & $09: 30-12: 00$ & $\begin{array}{l}\text { Defined four phases for SBWR startup. } \\
\text { Discussed criteria for defining phases. } \\
\text { Discussed the need for scaling analysis. } \\
\text { Decided to collect all relevant papers. }\end{array}$ & BNL Team \\
\hline 3 & $01-15-95$ & $10: 00-12: 00$ & $\begin{array}{l}\text { Revised the four phases for the startup. } \\
\text { Discussed possible instability in each } \\
\text { phase and associated phenomena. } \\
\text { Discussed important components for } \\
\text { startup stability. } \\
\text { Collected and distributed relevant papers. }\end{array}$ & BNL Team \\
\hline 4 & $02-08-95$ & $14: 00-17: 00$ & $\begin{array}{l}\text { Discussed characterization of phases. } \\
\text { Decided defining criteria for phases. } \\
\text { Finalized the definitions of four phases. } \\
\text { Produced characterization curves for the } \\
\text { four phases. }\end{array}$ & BNL Team \\
\hline 5 & $03-20-95$ & $09: 40-12: 00$ & $\begin{array}{l}\text { Discussed tabulation of the four phases. } \\
\text { Produced tabulation for the four phases } \\
\text { based on GE's proposed startup steps. } \\
\text { Tabulated components in SBWR startup. }\end{array}$ & BNL Team \\
\hline 6 & $03-22-95$ & $10: 00-12: 00$ & $\begin{array}{l}\text { Discussed ranking of Phase I and II. } \\
\text { Finalized PIRTs for Phase I and II. }\end{array}$ & BNL Team \\
\hline 7 & $03-23-95$ & $09: 30-12: 30$ & $\begin{array}{l}\text { Discussed ranking of Phase III and IV. } \\
\text { Compiled a list of questions for GE. } \\
\text { Finalized PIRTs for Phase III and IV. } \\
\text { Decided outline for the PIRT report. }\end{array}$ & BNL Team \\
\hline 8 & $06-07-95$ & $08: 30-05: 00$ & $\begin{array}{l}\text { Discussed GE SBWR Restart process. } \\
\text { Discussed PIRT procedures. } \\
\text { Introduced background material: } \\
\quad \text { - calculations } \\
\text { - tests } \\
\text { Reviewed phases, phenomena, \& ranking. }\end{array}$ & BNL Team \\
\hline
\end{tabular}




\section{APPENDIX D MINUTES OF MEETING BETWEEN BNL STAFF, USNRC PERSONNEL AND EXTERNAL CONSULTANTS.}


Subject: $\quad$ Minutes of the meeting held for review of PIRT on SBWR startup.

Location: Brookhaven National Laboratory

Date: June 7, 1995

Time: $\quad$ 8:30 a.m.- 4:00 p.m.

Participants: D. Carlson, H.S. Cheng, P. Griffith, Ed Kendrick, H. Khan, Jose March Leuba, U.S. Rohatgi, A. Ulses, and W. Wulff

The objective of the meeting was to obtain feedback from the participants on PIRT for SBWR start-up developed at BNL and on the PIRT report. The presentation in the meeting followed the outline of the PIRT report. An agenda of the meeting is provided in Appendix $A$.

BNL participants presented material pertaining to the startup procedure of the SBWR, background information on possible instabilities and PIRT. Justifications of the original rankings provided by the BNL team were discussed and clarified in this meeting. New rankings in the PIRT were developed with the clarification of the validity of some processes. Simple analytical calculations were suggested to verify the importance of phenomena like geysering and condensation induced oscillations. The meeting comments have been arranged into four groups and are presented in Appendix B. These comments are summarized here.

In the first section of the meeting, the SBWR features, the GE's start-up procedure and the possibility of instabilities were discussed. The details of GE's procedure have not been finalized yet. However, there are enough details available to model the thermal-hydraulics of the transient. The transient was divided into four distinct periods, namely, Subcooled Heat-up, Subcooled Chimney, Saturated Chimney and Power Ascension, for developing PIRT.

Prof. Griffith suggested that there could be instability due to internal circulation in the chimney section and core/chminey interface. He also commented that condensation induced instability ( Geysering) is not possible in SBWR and suggested that simple calculations be performed to eliminate the possibility. In case geysering does $\alpha c c u r$, it will be localized to chimney sections. It was a general consensus that some analyses should be performed to find the maximum heat-up rate which will cause geysering. Also there was a consensus that the names of the instabilities should be changed and they should be clearly defined. For example the geysering instability name has been used to describe two types of instabilities. Prof. Griffith used it to define bubble growth due to the reduction in hydrostatic head and expulsion of the bubbles, while Prof. Aritomi used it for condensation induced instability. It was the consensus that Geysering in SBWR should be replaced by Condensation Induced Instability in SBWR.

In the second section of the meeting some of the results from RAMONA-4B and GE's analyses with TRACG were presented. The objective of this section was to familiarize the participants with the possible conditions in the reactor and duration of each phase of the transient. In general there was good agreement between TRACG and RAMONA-4B results. There were concerns about a single chimney model in RAMONA-4B, loss coefficients at the orifices at low flows and liquid superheat at the core exit. These items should be investigated. 
In the third section of the meeting results from the tests relevant to SBWR start-up were described. Dr. MarchLeuba commented that instability was observed in the Dodewaard reactor start-up which was not measured earlier. GE has earlier claimed that Dodewaard never experienced instability. Prof. Griffith suggested two other test data should be looked at. These are Canadian reactor natural circulation data and GE/KAPL data about natural circulation and burnout data. He commented that Aritomi's test and test from Taiwan do not apply to SBWR and suggested that nondimensional groups be evaluated and compared with similar groups in SBWR to eliminate these tests. He also suggested that low pressure data are very uncertain and not much available. The CRIEPI tests (Japan) were affected by the components outside of the vessel (system effect) and the results should be carefully evaluated.

The fourth section deals with the actual PIRT. The phenomena list and their rankings were discussed in the meeting. About 53 rankings out of 170 rankings were changed on the basis of discussion. All except for one were changed to lower ranking. The separator pressure drop was deemed to be important for stability. The vapor generation will first begin at the top of the chimney and will begin in the core later. Therefore, Net Vapor Generation (NVG) should be restricted to core for phase identification. Prof. Griffith suggested a different criterion for the occurrence of density waves. His criterion is based on the ratio of single phase and total pressure drops in the channel, and on the ratio of channel exit and inlet velocities. He also indicated that loop type oscillations are also possible in the last phase of start-up. 

Table E.1 Detailed Description of Components

\begin{tabular}{|c|c|c|}
\hline Component Number & Component Name & Component and Geometry Description \\
\hline $\mathrm{Cl}$ & Downcomer & $\begin{array}{l}\text { The downcomer consists of the annular region between } \\
\text { the core and chimney on the inside and the RPV wall } \\
\text { on the outside. Saturated water from the separator/dryer } \\
\text { and feedwater flow downward to the lower plenum. } \\
\text { The feedwater lines, IC condensate return lines, the } \\
\text { GDCS injection lines and equalization lines, as well as } \\
\text { the RWCU/SDC lines feed into it. Also, several safety } \\
\text { system are sctuated on the basis of the collapsed liquid } \\
\text { level between wide range level instrument connection } \\
\text { points in the downcomer. The liquid level during steady } \\
\text { state operation is at } 18.3 \mathrm{~m} \text {. The downcomer average } \\
\text { cross section area is } 8.2 \mathrm{~m}^{2} \text {. }\end{array}$ \\
\hline $\mathrm{C} 2$ & Lower Plenum & $\begin{array}{l}\text { The lower plenum consists of the close-to-semi- } \\
\text { spherical space below the core and the downcomer. } \\
\text { The coolant from the downcomer passes through the } \\
\text { lower plenum before entering the core. This region } \\
\text { also contains the control rods with the required } \\
\text { penetrations and associated hardware. }\end{array}$ \\
\hline C3 & Guide Tube & $\begin{array}{l}\text { Guide tubes of SBWR enter the core support plate } \\
\text { from the bottom and passes through the space in } \\
\text { between four adjacent fuel assemblies. Control rods } \\
\text { movement is guided through theses tubes. }\end{array}$ \\
\hline $\mathrm{C} 4$ & Core Bypass & $\begin{array}{l}\text { Most of the coolant flows through the fuel assembly } \\
\text { channels, with some bypass flow, being directed into } \\
\text { the bypass region through holes in the lower tie plate. } \\
\text { The flow area of the bypass region is } 5.6 \mathrm{~m}^{2} \text {. The } \\
\text { bypass flow is orificed, to amount to about } 19 \% \text { of the } \\
\text { total core flow during normal full power operation. }\end{array}$ \\
\hline C5 & Chimney and Upper Plenum & $\begin{array}{l}\text { On top of the core, the SBWR has a chimney section, } \\
\text { which is } 9 \mathrm{~m} \text { long to provide the required buoyancy } \\
\text { force for natural circulation. The chimney region is } \\
\text { partitioned into } 25 \text { separate flow channels, generally } \\
\text { with } 36 \text { fuel assemblies each. }\end{array}$ \\
\hline
\end{tabular}


Table E.1 Detailed Description of Components

\begin{tabular}{|c|c|c|}
\hline Component Number & Component Name & Component and Geometry Description \\
\hline C6 & Separator /Dryer & $\begin{array}{l}\text { During normal operation, two phase mixture flows } \\
\text { from the chimney to the separator/dryer component. In } \\
\text { the separator section swirl vanes separate the liquid } \\
\text { from the vapor by centrifugal force. In the dryer section } \\
\text { the steam flows horizontally outward through } \\
\text { corrugated vanes, with any remaining liquid being } \\
\text { collected on these vanes, flowing downward, to be } \\
\text { returned to the downcomer region, while vapor exits } \\
\text { into the steam dome. }\end{array}$ \\
\hline C7 & Reactor Core & $\begin{array}{l}\text { The core consists of } 732 \text { fuel assemblies, each with an } \\
8 \times 8 \text { rod configuration, containing } 60 \text { fuel rods. The } \\
\text { fuel rod length is } 2.743 \mathrm{~m} \text {. The fuel rod outer diameter } \\
\text { is } 12.27 \mathrm{~mm} \text {. The coolant flow area in each assembly } \\
\text { is } 0.01011 \mathrm{~m}^{2} \text {, for a total active core flow area of } 7.4 \\
\mathrm{~m}^{2} \text {. }\end{array}$ \\
\hline $\mathrm{C} 8$ & Steam Dome & $\begin{array}{l}\text { The steam dome at the top of the reactor pressure } \\
\text { vessel consists of the space outside the steam } \\
\text { separator. Vapor released from the separators are } \\
\text { collected in the steam dome. The diameter of this } \\
\text { hemispherical space is } 6.0 \text { meters. Two steam lines and } \\
\text { stub tubes for the isolation condenser are connected to } \\
\text { the steam dome. }\end{array}$ \\
\hline C9 & Balance of Plant & $\begin{array}{l}\text { Operation of the reactor is balanced through a set of } \\
\text { dynamic controllers with their feedback systems. Set } \\
\text { points corresponding to the desired operating } \\
\text { conditions are used to control the performance of the } \\
\text { reactor. Balance of plant consists of the set of systems } \\
\text { which are active during plant operation. }\end{array}$ \\
\hline
\end{tabular}


Table E.2 Detailed Description of Phenomena

\begin{tabular}{|c|c|c|}
\hline Phenomenon & Name & Phenomenon Description \\
\hline P1 & Level Motion & $\begin{array}{l}\text { In the chimney and downcomer sections a two phase level } \\
\text { can exist. This level is characterized by a sharp change in } \\
\text { void fraction. The location of the level will depend upon } \\
\text { interfacial shear and flow regime. Several of the safety } \\
\text { signals are based on the "Downcomer Wide Range } \\
\text { Level", which is a measurement of hydrostatic head across } \\
\text { two taps. This is effectively a "collapsed level", I e. the } \\
\text { level of integrated liquid above the bottom tap. }\end{array}$ \\
\hline P2 & Heat Slabs/Stored Energy & Energy stored in solid structure of the reactor \\
\hline P3 & Flashing & $\begin{array}{l}\text { Vapor generation due to depressurization. Sudden } \\
\text { change in pressure can occur during a transient or flow } \\
\text { oscillations. Since there is a large pressure gradient } \\
\text { between the top and bottom of the RPV, flashing due to } \\
\mathrm{dP} / \mathrm{dT} \text { and } \mathrm{dP} / \mathrm{dZ} \text { are both important. }\end{array}$ \\
\hline P4 & Feedwater Injection & $\begin{array}{l}\text { Injection of preheated water into the reactor through a set } \\
\text { of spurgers occurs in the downcomer. At normal } \\
\text { operation the feectwater flow rate of the SBWR is equal to } \\
1080 \mathrm{~kg} / \mathrm{sec} \text {, which balance the steam production rate of } \\
\text { the reactor. The feedwater temperature is } 215^{\circ} \mathrm{C}\end{array}$ \\
\hline P5 & $1 \varphi$ Pressure Drop & $\begin{array}{l}\text { Pressure drop due to wall friction and local losses, such as } \\
\text { orifices. This pressure drop will control the flow in } \\
\text { individual flow passages and the natural circulation flow } \\
\text { in the core. The available correlations must cover single } \\
\text { phase and two-phase flow. }\end{array}$ \\
\hline P6 & CRD Flow Injection & $\begin{array}{l}\text { The control rod drive mechanism is cooled externally } \\
\text { through the CRD flow. This is a flow rate of } 3.83 \mathrm{~kg} / \mathrm{sec} \\
\text { at } 49^{\circ} \mathrm{C} \text {. }\end{array}$ \\
\hline P7 & Flow Leakage/Refill & $\begin{array}{l}\text { Leakage flow from the fuel assembly to the bypass region } \\
\text { occurs in the lower tie plate and the core support plate. }\end{array}$ \\
\hline P8 & $\begin{array}{l}\text { Rod Worth and Control } \\
\text { Rod Pattern }\end{array}$ & $\begin{array}{l}\text { Insertion and removal of the control rods into the core } \\
\text { take place through the guide tubes at the bottom of the } \\
\text { reactor. }\end{array}$ \\
\hline P9 & 3D Kinetics & $\begin{array}{l}\text { 3D power distribution is achieved by a 3D control rod } \\
\text { distribution. }\end{array}$ \\
\hline $\mathrm{P} 10$ & Void Feedback & Effect of void fraction on reactivity \\
\hline P11 & Doppler Feedback & Effect of fuel temperature on reactivity \\
\hline $\mathrm{P} 12$ & Moderator Feedback & Effect of coolant temperature on reactivity \\
\hline
\end{tabular}


Table E.2 Detailed Description of Phenomena

\begin{tabular}{|c|c|c|}
\hline Phenomenon & Name & Phenomenon Description \\
\hline $\mathrm{P} 13$ & Flux Depression & Non uniform flux distribution in the fuel pellet \\
\hline P14 & Gap Conductance & Conductivity of inert gas between the pellet and cladding \\
\hline P15 & Heat Transfer & $\begin{array}{l}\text { Convective heat transfer from a solid surface to the } \\
\text { adjacent coolant. The heat transfer correlations must } \\
\text { cover single phase and two phase flow. }\end{array}$ \\
\hline P16 & Post CHF/Rewet & $\begin{array}{l}\text { Departure from nucleate boiling and beginning of film } \\
\text { boiling can occur at high wall superheat }\end{array}$ \\
\hline P17 & $2 \varphi$ Pressure Drop & $\begin{array}{l}\text { Pressure drop due to friction and form losses during a two } \\
\text { phase flow. Two phase pressure drop is a strong function } \\
\text { of the vapor fraction and pressure. }\end{array}$ \\
\hline P18 & $\begin{array}{l}\text { Subcooled } \\
\text { Boiling/Condensation }\end{array}$ & $\begin{array}{l}\text { During the early part of startup, the coolant remains } \\
\text { subcooled in the reactor. Since saturation temperature } \\
\text { increases from the top of the water level to the bottom of } \\
\text { the RPV, first subcooled boiling initiates on the wall at } \\
\text { the top of the core. This boiling boundary moves down } \\
\text { the core height with time. Condensation of vapor } \\
\text { continues until the bulk liquid in the core is saturated. }\end{array}$ \\
\hline P19 & $\begin{array}{l}\text { Evaporation/ } \\
\text { Equalization Boiling }\end{array}$ & $\begin{array}{l}\text { Vapor generation at the interface of liquid and vapor due } \\
\text { to heat transfer from fuel and other solid structures to the } \\
\text { coolant. }\end{array}$ \\
\hline $\mathrm{P} 20$ & Phase Separation & $\begin{array}{l}\text { This phenomenon is specific to separators. The phases are } \\
\text { separated by swirl vanes exerting centrifugal force on the } \\
\text { fluid, driving the liquid to the outer wall, for withdrawal } \\
\text { to the downcomer. }\end{array}$ \\
\hline P21 & $\begin{array}{l}\text { Flow Circulation and } \\
\text { Distribution }\end{array}$ & $\begin{array}{l}\text { Natural circulation flow inside the chimney can distribute } \\
\text { due to secondary flows generated near the comers and the } \\
\text { cold walls during the early part of startup. }\end{array}$ \\
\hline P22 & Condensation & $\begin{array}{l}\text { Condensation of vapor generated in the core can take } \\
\text { place within the chimney during startup. During } \\
\text { oscillations and flow reversal, condensation can take } \\
\text { place in the lower plenum. }\end{array}$ \\
\hline P23 & Separator Inertia & Effect of spiral flow path within the separator \\
\hline P24 & Carryunder & $\begin{array}{l}\text { Steam carried back to the downcomer with liquid } \\
\text { returning from the separator. }\end{array}$ \\
\hline P25 & Carryovet & Moisture carried along with steam into the steam dome. \\
\hline
\end{tabular}


Table E.2 Detailed Description of Phenomena

\begin{tabular}{|c|c|c|}
\hline Phenomenon & Name & Phenomenon Description \\
\hline P26 & Feedwater Flow Dynamics & $\begin{array}{l}\text { This consists of feedwater pump dynamics and feedwater } \\
\text { flow rate. }\end{array}$ \\
\hline P27 & $\begin{array}{l}\text { Feedwater Heater } \\
\text { Dynamics }\end{array}$ & $\begin{array}{l}\text { Dynamics of feedwater heater consists of flow and energy } \\
\text { balance of the steam extracted from the turbine and water } \\
\text { returned from the condenser. }\end{array}$ \\
\hline P28 & Steamline Dynamics & $\begin{array}{l}\text { This consists of the dynamics of main steam isolation } \\
\text { valve, bypass flow and pressure in the steam line. }\end{array}$ \\
\hline P29 & Turbine Dynamics & $\begin{array}{l}\text { This consists of the dynamics of flow and pressure across } \\
\text { the turbine. }\end{array}$ \\
\hline P30 & Condenser Dynamics & $\begin{array}{l}\text { This consists of mass and energy balance within the } \\
\text { condenser. }\end{array}$ \\
\hline P31 & $\begin{array}{l}\text { Pressure Regulator } \\
\text { Dynamics } \\
\end{array}$ & $\begin{array}{l}\text { Valve position of the turbine control valve and the bypass } \\
\text { valve are regulated by the pressure regulator }\end{array}$ \\
\hline P32 & $\begin{array}{l}\text { Feedwater Control System } \\
\text { Dynamics }\end{array}$ & $\begin{array}{l}\text { Mismatch of feed water flow and steam flow is balanced } \\
\text { in response to the level signal from the downcomer. }\end{array}$ \\
\hline P33 & $\begin{array}{l}\text { RWCU System Level } \\
\text { Control }\end{array}$ & $\begin{array}{l}\text { During the early part of startup, reactor water cleanup } \\
\text { system is used in a heat up mode. It is also used to } \\
\text { control the level by removing liquid after level swell due } \\
\text { vapor generation and expansion. }\end{array}$ \\
\hline
\end{tabular}


Table F.1 Phase I: Subcooled Heatup (0stst,)

\begin{tabular}{|c|c|c|c|c|c|c|}
\hline \multicolumn{4}{|c|}{ Subcooled, Single-Phase Heatup, Condensation-Induced Oscillations } & \multicolumn{2}{|c|}{ Event Phase: Phase I } & \multirow[t]{2}{*}{ Page No: 1} \\
\hline Component & $\begin{array}{l}\text { Type of } \\
\text { Geometry }\end{array}$ & Phenomenon & $\begin{array}{l}\text { Phenomenon } \\
\text { Description }\end{array}$ & Rank & Ranking Rationale & \\
\hline \multirow[t]{5}{*}{ Downcomer } & \multirow[t]{5}{*}{ Anmulus } & Level Motion & P1 & NA & \multicolumn{2}{|c|}{$\begin{array}{l}\text { NA, Level not in downcomer } \\
\text { (level in dome) }\end{array}$} \\
\hline & & Heat Slabs/Stored Energy & $\mathbf{P 2}$ & $\mathbf{L}$ & \multicolumn{2}{|c|}{$\begin{array}{l}\text { Ratio of }\left(\mathrm{Mc} c_{\mathrm{p}}\right) \text { for structure and } \\
\text { fluid is } 2.59 \% \text { of that of the core. }\end{array}$} \\
\hline & & Flashing & P3 & NA & \multicolumn{2}{|c|}{$\begin{array}{l}\text { NA, Pressure is more than } \\
\text { saturation pressure }\end{array}$} \\
\hline & & Feedwater Injection & P4 & NA & \multicolumn{2}{|c|}{ NA, No feedwater injected yet } \\
\hline & & 1- $\phi$ Pressure Drop & P5 & L & \multicolumn{2}{|c|}{$\begin{array}{l}\text { Small pressure drop relative to } \\
\text { that of core }\end{array}$} \\
\hline \multirow[t]{4}{*}{ Lower Plemum } & \multirow{4}{*}{$\begin{array}{l}\text { Pipe,Structure } \\
\text { Horizontal } \\
\text { Vertical }\end{array}$} & Heat Slabs/Stored Energy & $\mathbf{P 2}$ & L & \multicolumn{2}{|c|}{$\begin{array}{l}\text { Ratio of }\left(\mathrm{Mc}_{\mathrm{p}}\right) \text { for structure and } \\
\text { fluid is } 2.59 \% \text { of that of the core. }\end{array}$} \\
\hline & & CRD Flow Injection & P6 & $\mathbf{M}$ & \multicolumn{2}{|c|}{$\begin{array}{l}\text { It is the only relevant in the } \\
\text { beginning, later on it is } 30 \% \text { of } \\
\text { RWCU flow. }\end{array}$} \\
\hline & & Flashing & P3 & NA & \multicolumn{2}{|c|}{$\begin{array}{l}\text { NA, Pressure is more than } \\
\text { saturation pressure }\end{array}$} \\
\hline & & 1- $\phi$ Pressure Drop & P5 & I & \multicolumn{2}{|c|}{ Small pressure drop at low flow } \\
\hline \multirow[t]{2}{*}{ Guide Tube } & \multirow[t]{4}{*}{ Pipe } & Flashing & P3 & NA & \multicolumn{2}{|c|}{$\begin{array}{l}\text { NA, Pressure is more than } \\
\text { saturation pressure }\end{array}$} \\
\hline & & Flow Leakage/Refill & P7 & L & \multicolumn{2}{|c|}{$\begin{array}{l}\text { It contributes to bypass flow up to } \\
18.5 \%\end{array}$} \\
\hline \multirow[t]{2}{*}{ C3 } & & & & & & \\
\hline & & & & & \\
\hline
\end{tabular}


Table F.1 Phase I: Subcooled Heatup (0st) (Cont'd)

\begin{tabular}{|c|c|c|c|c|c|c|}
\hline \multicolumn{4}{|c|}{ Subcooled, Single-Phase Heatup, Condensation-Induced Oscillations } & \multicolumn{2}{|c|}{ Event Phase: Phase I } & Page No: 2 \\
\hline Component & $\begin{array}{l}\text { Type of } \\
\text { Geometry }\end{array}$ & Phenomenon & $\begin{array}{l}\text { Phenomenon } \\
\text { Description }\end{array}$ & Rank & \multicolumn{2}{|c|}{ Ranking Rationale } \\
\hline \multirow[t]{4}{*}{ Core Bypass } & \multirow[t]{4}{*}{$\begin{array}{l}\text { Vertical } \\
\text { Channel }\end{array}$} & Heat Slabs/Stored Energy & $\mathbf{P} 2$ & $\mathbf{M}$ & \multicolumn{2}{|c|}{$\begin{array}{l}\text { Ratio of mass of structure is } 75 \% \\
\text { of the core. Ratio of flow is } 18 \% \\
\text { of the core. Temperature of } \\
\text { structure is low }\end{array}$} \\
\hline & & Flashing & P3 & NA & \multicolumn{2}{|c|}{$\begin{array}{l}\text { NA, Pressure is more than } \\
\text { saturation pressure }\end{array}$} \\
\hline & & 1- $\phi$ Pressure Drop & P5 & M & \multicolumn{2}{|c|}{$\begin{array}{l}\text { Determines the flow split } \\
\text { between channels }\end{array}$} \\
\hline & & $\begin{array}{l}\text { Heat Transfer To Bypass } \\
\text { Channel }\end{array}$ & P15 & $\mathbf{L}$ & \multicolumn{2}{|c|}{$\begin{array}{l}\text { Temperature is low and relatively } \\
\text { uniform }\end{array}$} \\
\hline \multirow{4}{*}{$\begin{array}{l}\text { Chimney and } \\
\text { Upper Plemum } \\
\text { C5 }\end{array}$} & \multirow[t]{4}{*}{$\begin{array}{l}\text { Pipe,Struct } \\
\text { ure }\end{array}$} & Phase Separation & $\mathbf{P} 20$ & NA & \multicolumn{2}{|c|}{$\begin{array}{l}\text { NA, Single phase only (no vapor } \\
\text { generated) }\end{array}$} \\
\hline & & $\begin{array}{l}\text { Flow Circulation and } \\
\text { Distribution }\end{array}$ & $\mathbf{P 2 1}$ & L & \multicolumn{2}{|c|}{ Single phase and flow is uniform } \\
\hline & & Condensation & $\mathbf{P 2 2}$ & NA & \multicolumn{2}{|c|}{ NA, No vapor generated yet } \\
\hline & & Level Motion & P1 & NA & \multicolumn{2}{|c|}{ NA, Level is in steam dome } \\
\hline \multirow{5}{*}{$\begin{array}{l}\text { Separator and } \\
\text { Dryer } \\
\text { C6 }\end{array}$} & \multirow[t]{5}{*}{ Swirl Vanes } & Pressure Drop & P17 & L & \multicolumn{2}{|c|}{$\begin{array}{l}\text { Main contributor to ex-core } \\
\text { pressure drop }\end{array}$} \\
\hline & & Separator Inertia L/A & $\mathbf{P} 23$ & L & \multicolumn{2}{|c|}{ Low flow therefore of less } \\
\hline & & Carryunder & P24 & NA & \multicolumn{2}{|c|}{ NA, No vapor generated yet } \\
\hline & & Carryover & $\mathrm{P} 25$ & NA & \multicolumn{2}{|c|}{ No vapor generated yet } \\
\hline & & Level Motion & $\mathrm{P} 1$ & NA & \multicolumn{2}{|c|}{ NA, Level is in steam dome } \\
\hline
\end{tabular}


Table F.1 Phase I: Subcooled Heatup (0 $\left.\leq t \leq \tau_{1}\right)$ (Cont'd)

\begin{tabular}{|c|c|c|c|c|c|c|}
\hline \multicolumn{4}{|c|}{ Subcooled, Single-Phase Heatup, Condensation-Induced Oscillations } & \multicolumn{2}{|c|}{ Event Phase: Phase I } & Page No: 3 \\
\hline Component & $\begin{array}{l}\text { Type of } \\
\text { Geometry }\end{array}$ & Phenomenon & $\begin{array}{l}\text { Phenomenon } \\
\text { Description }\end{array}$ & Rank & \multicolumn{2}{|c|}{ Ranking Rationale } \\
\hline \multirow{16}{*}{$\begin{array}{l}\text { Reactor Core } \\
\text { C7 }\end{array}$} & \multirow[t]{16}{*}{$\begin{array}{l}\text { Vertical } \\
\text { Channels }\end{array}$} & $\begin{array}{l}\text { Rod Worth and Rod } \\
\text { Pattern }\end{array}$ & P8 & $\mathrm{H}$ & \multicolumn{2}{|c|}{$\begin{array}{l}\text { Control rods are withdrawn to } \\
\text { control power ascension }\end{array}$} \\
\hline & & 3D Kinetics Dynamics & P9 & $\mathrm{H}$ & \multicolumn{2}{|c|}{$\begin{array}{l}\text { Power peaking may be high due } \\
\text { to control rod widthrawal pattern }\end{array}$} \\
\hline & & Void Feedback & P10 & NA & \multicolumn{2}{|c|}{$\begin{array}{l}\text { Little or no void if any because } \\
\text { of low power }\end{array}$} \\
\hline & & Doppler Feedback & P11 & $\mathrm{H}$ & \multicolumn{2}{|c|}{$\begin{array}{l}\text { The main feedback compensating } \\
\text { rod worth for criticality }\end{array}$} \\
\hline & & Moderator Feedback & P12 & $\mathrm{H}$ & \multicolumn{2}{|c|}{$\begin{array}{l}\text { Moderator temperature feedback } \\
\text { helps compensating the rod worth } \\
\text { for criticality }\end{array}$} \\
\hline & & Structure Stored Energy & $\mathbf{P} 2$ & L & \multicolumn{2}{|c|}{$\begin{array}{l}\text { Ratio of }\left(\mathrm{Mc}_{\mathrm{p}}\right) \text { for structure and } \\
\text { fluid is } 9.84 \text {. Temperature of } \\
\text { structure is low. Process is slow, } \\
\text { there is equilibrium and heating } \\
\text { is low. }\end{array}$} \\
\hline & & Fuel Stored Energy & $\mathrm{P} 2$ & $\mathrm{~L}$ & \multicolumn{2}{|c|}{$\begin{array}{l}\text { Minor contributor to coolant } \\
\text { temp. increase }\end{array}$} \\
\hline & & Flux Depression & P13 & $\mathbf{L}$ & \multicolumn{2}{|c|}{$\begin{array}{l}\text { Effect on fuel centerline } \\
\text { temperature is low and therefore } \\
\text { unimportant }\end{array}$} \\
\hline & & Gap Conductance & P14 & $\mathrm{L}$ & \multicolumn{2}{|c|}{$\begin{array}{l}\text { It affects mainly centerline temp. } \\
\text { that is low }\end{array}$} \\
\hline & & Heat Transfer & P15 & $\mathbf{M}$ & \multicolumn{2}{|c|}{$\begin{array}{l}\text { Main contributor to coolant temp. } \\
\text { increase }\end{array}$} \\
\hline & & Post CHF/Rewet & P16 & NA & \multicolumn{2}{|c|}{$\begin{array}{l}\text { NA, Temperature is too low for } \\
\text { post CHF }\end{array}$} \\
\hline & & 1- $\phi$ Pressure Drop & P5 & L & \multicolumn{2}{|c|}{$\begin{array}{l}\text { The controlling factor for core } \\
\text { flow }\end{array}$} \\
\hline & & 2- $\phi$ Pressure Drop & P17 & NA & \multicolumn{2}{|c|}{ NA, No vapor generated yet } \\
\hline & & $\begin{array}{l}\text { Subcooled Boiling } \\
\text { /Condensation }\end{array}$ & P18 & $\mathbf{M}$ & \multicolumn{2}{|c|}{$\begin{array}{l}\text { Determines the boundary of the } \\
\text { phase }\end{array}$} \\
\hline & & Evaporation & P19 & NA & \multicolumn{2}{|c|}{ NA, Liquid is subcooled } \\
\hline & & Flashing & P3 & NA & \multicolumn{2}{|c|}{$\begin{array}{l}\text { NA, Pressure is more than } \\
\text { saturation pressure }\end{array}$} \\
\hline
\end{tabular}


Table F.1 Phase I: Subcooled Heatup $\left(0 \leq t \leq \tau_{1}\right)$ (Cont'd)

\begin{tabular}{|c|c|c|c|c|c|c|}
\hline \multicolumn{4}{|c|}{ Subcooled, Single-Phase Heatup, Condensation-Induced Oscillations } & \multicolumn{2}{|c|}{ Event Phase: Phase I } & \multirow[t]{2}{*}{ Page No: 4} \\
\hline Component & $\begin{array}{l}\text { Type of } \\
\text { Geometry }\end{array}$ & Phenomenon & $\begin{array}{c}\text { Phenomenon } \\
\text { Description }\end{array}$ & Rank & Ranking Rationale & \\
\hline \multirow[t]{5}{*}{ Steam Dome } & \multirow[t]{5}{*}{$\begin{array}{l}\text { Hemi- } \\
\text { Sphere }\end{array}$} & Condensation & $\mathrm{P} 23$ & NA & \multicolumn{2}{|c|}{ NA, No vapor generated yet } \\
\hline & & Heat Slabs/Stored Energy & $\mathrm{P} 2$ & $\mathrm{~L}$ & \multicolumn{2}{|c|}{$\begin{array}{l}\text { Ratio of }\left(\mathrm{Mc}_{\mathrm{p}}\right) \text { for structure and } \\
\text { fluid is } 1.17 \% \text { of that of the core. }\end{array}$} \\
\hline & & Evaporation & $\mathrm{P} 20$ & NA & \multicolumn{2}{|c|}{ NA, No vapor generated yet } \\
\hline & & Level Motion & P1 & L & \multicolumn{2}{|c|}{$\begin{array}{l}\text { Level motion in dome, controls } \\
\text { core flow }\end{array}$} \\
\hline & & Phase Separation & $\mathrm{P} 21$ & $\mathrm{NA}$ & \multicolumn{2}{|c|}{ NA, No vapor generated yet } \\
\hline $\begin{array}{l}\text { Balance of } \\
\text { Plant }\end{array}$ & \multirow{5}{*}{$\begin{array}{l}\text { Pipes, } \\
\text { Pumps, } \\
\text { Exchangers } \\
\text { ' } \\
\text { Valves, etc. }\end{array}$} & Feedwater Flow Dynamics & P26 & NA & \multicolumn{2}{|c|}{ NA, No feedwater flow yet } \\
\hline \multirow[t]{4}{*}{$\mathrm{C} 9$} & & $\begin{array}{l}\text { Feedwater Heater } \\
\text { Dynamics }\end{array}$ & $\mathrm{P} 27$ & NA & \multicolumn{2}{|c|}{$\begin{array}{l}\text { NA, No feedwater flow yet, } \\
\text { feedwater heaters not operational } \\
\text { (turbine control valve is closed) }\end{array}$} \\
\hline & & Steamline Dynamics & P28 & L & \multicolumn{2}{|c|}{$\begin{array}{l}\text { Only used for deaerating the } \\
\text { vessel }\end{array}$} \\
\hline & & Turbine Dynamics & P29 & $\mathrm{NA}$ & \multicolumn{2}{|c|}{$\begin{array}{l}\text { NA, Turbines not operational } \\
\text { (TCV closed) }\end{array}$} \\
\hline & & $\begin{array}{l}\text { Condenser } \\
\text { Dynamics } \\
\end{array}$ & P30 & $\mathbf{M}$ & \multicolumn{2}{|c|}{$\begin{array}{l}\text { Air removal through the } \\
\text { condenser }\end{array}$} \\
\hline
\end{tabular}


Table F.1 Phase I: Subcooled Heatup (0st $\left.s \tau_{1}\right)$ (Cont'd)

\begin{tabular}{|c|c|c|c|c|c||}
\hline \multicolumn{2}{|c|}{ Subcooled, Single-Phase Heatup, Condensation-Induced Oscillations } & \multicolumn{2}{l|}{ Event Prase: Phase I } & Page No: 5 \\
\hline Component & $\begin{array}{c}\text { Type of } \\
\text { Geometry }\end{array}$ & Phenomenon & $\begin{array}{c}\text { Phenomenon } \\
\text { Description }\end{array}$ & Rank & Ranking Rationale \\
\hline \hline $\begin{array}{c}\text { Control } \\
\text { Systems } \\
\text { C10 }\end{array}$ & Wires, Circuits & $\begin{array}{c}\text { Pressure Regulator } \\
\text { Dynamics }\end{array}$ & P31 & NA & $\begin{array}{c}\text { NA, Pressure is low therefore } \\
\text { control is not necessary }\end{array}$ \\
\cline { 2 - 6 } & $\begin{array}{c}\text { Feedwater Control } \\
\text { System Dynamics }\end{array}$ & P32 & NA & NA, No feedwater flow yet \\
\cline { 2 - 6 } & $\begin{array}{c}\text { RWCU System Level } \\
\text { Control }\end{array}$ & P33 & H & $\begin{array}{c}\text { Level is controlled by the } \\
\text { reactor water cleanup unit } \\
\text { (RWCU) }\end{array}$ \\
\hline
\end{tabular}


Table F.2 Phase II: Subcooled Chimney $(\tau, \leq t \leq \tau)$

\begin{tabular}{|c|c|c|c|c|c|}
\hline \multicolumn{4}{|c|}{$\begin{array}{l}\text { Subcooled Chimney, Condensation-Induced Oscillation, } \\
\text { Net Vapor Generation }\end{array}$} & \multicolumn{2}{|c|}{ Event Phase: Phase II } \\
\hline Component & $\begin{array}{l}\text { Type of } \\
\text { Geometry }\end{array}$ & Phenomenon & $\begin{array}{l}\text { Phenomenon } \\
\text { Description }\end{array}$ & Rank & Ranking Rationale \\
\hline \multirow[t]{5}{*}{ Downcomer } & \multirow[t]{5}{*}{ Annulus } & Level Motion & P1 & NA & $\begin{array}{l}\text { NA, Level not in downcomer (level in } \\
\text { dome) }\end{array}$ \\
\hline & & Heat Slabs/Stored Energy & P2 & L & $\begin{array}{l}\text { Ratio of }\left(\mathrm{Mc}_{\mathrm{p}}\right) \text { for structure and fluid is } \\
2.59 \% \text { of that of the core. Small effect } \\
\text { on core inlet subcooling. }\end{array}$ \\
\hline & & Flashing & P3 & L & Possibility of pressure oscillations \\
\hline & & Feedwater Injection & P4 & NA & NA, No feedwater injected yet \\
\hline & & 1- $\phi$ Pressure Drop & P5 & L & $\begin{array}{l}\text { Small pressure drop relative to that of the } \\
\text { core }\left(\frac{\hbar}{t}\right)\end{array}$ \\
\hline \multirow{4}{*}{$\begin{array}{l}\text { Lower } \\
\text { Plenum } \\
\text { C2 }\end{array}$} & \multirow{4}{*}{$\begin{array}{l}\text { Pipe } \\
\text { Structure } \\
\text { Horizontal } \\
\text { Vertical }\end{array}$} & Heat Slabs/Stored Energy & $\mathbf{P 2}$ & L & $\begin{array}{l}\text { Ratio of }\left(\mathrm{Mc}_{\mathrm{p}}\right) \text { for structure and fhid is } \\
2.8 \% \text { of that of the core.Small effect on } \\
\text { core inlet subcooling. }\end{array}$ \\
\hline & & CRD Flow Injection & P6 & L & $\begin{array}{l}\text { CRD flow is upto } 30 \% \text { of RWCU flow, } \\
\text { but small fraction core inlet flow }\end{array}$ \\
\hline & & Flashing & P3 & NA & $\begin{array}{l}\text { NA, Pressure is higher than saturation } \\
\text { pressure }\end{array}$ \\
\hline & & $1-\phi$ Pressure Drop & P5 & $\underline{L}$ & Small pressure drop at low flow (\#) \\
\hline \multirow[t]{2}{*}{ Guide Tube } & \multirow[t]{2}{*}{ Pipe } & Flashing & P3 & NA & $\begin{array}{l}\text { NA, Pressure is higher than saturation } \\
\text { pressure }\end{array}$ \\
\hline & & Flow Leakage/Refill & P7 & $\mathrm{L}$ & $\begin{array}{l}\text { It contributes to bypass flow which is lon } \\
\text { of the core flow }\end{array}$ \\
\hline
\end{tabular}


Table F.2 Phase II: Subcooled Chimney $\left(\tau_{1} \leq t \leq \tau_{2}\right)$ (Cont'd)

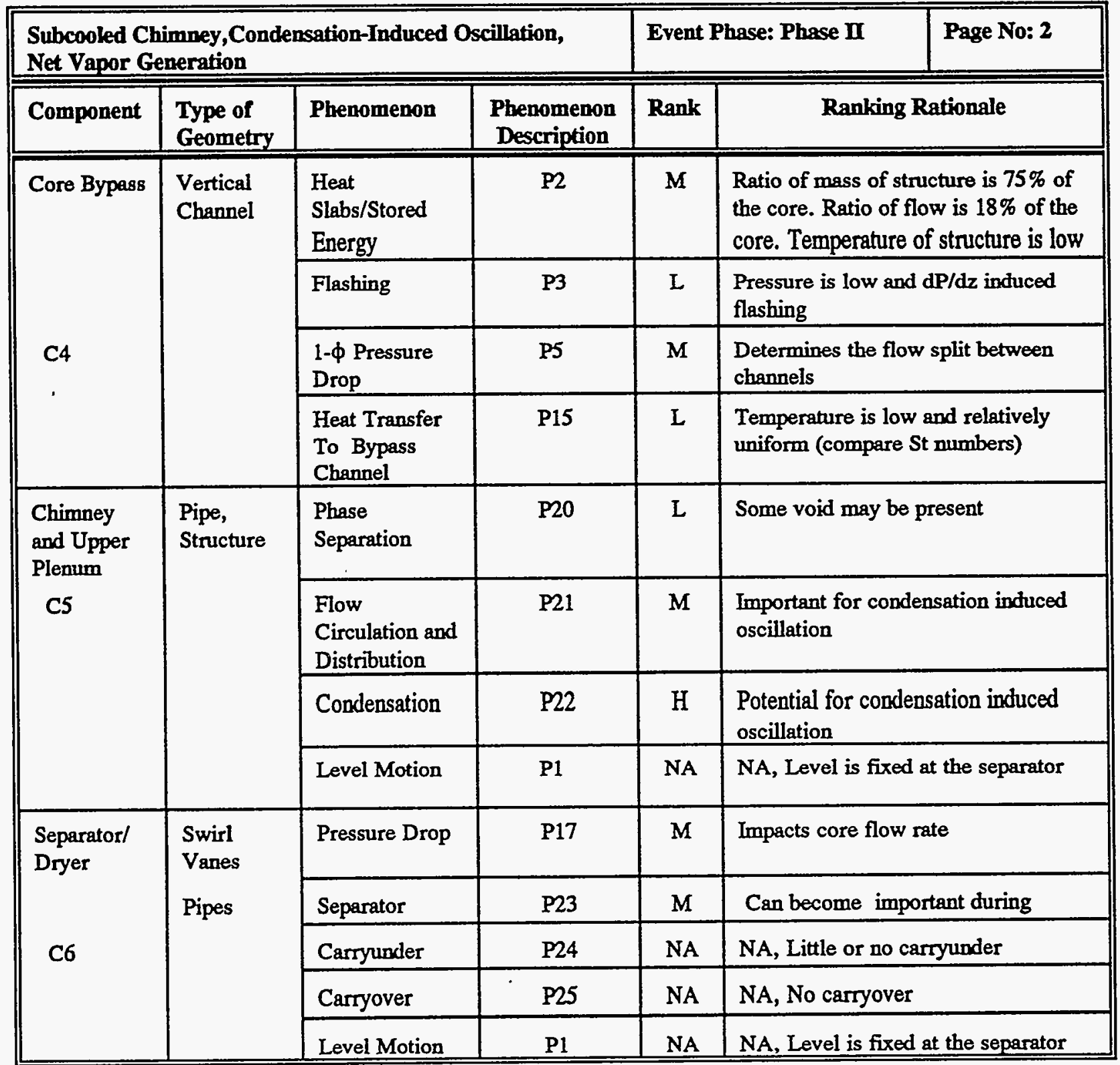


Table F.2 Phase II: Subcooled Chimney $\left(\tau_{1} \leq t \leq \tau_{2}\right)$ (Cont'd)

\begin{tabular}{|c|c|c|c|c|c|}
\hline \multicolumn{4}{|c|}{$\begin{array}{l}\text { Subcooled Chimney, Condensation-Induced Oscillation } \\
\text { Net Vapor Generation }\end{array}$} & \multicolumn{2}{|c|}{ Event Phase: Phase II } \\
\hline Component & $\begin{array}{l}\text { Type of } \\
\text { Geometry }\end{array}$ & Phenomenon & $\begin{array}{l}\text { Phenomenon } \\
\text { Description }\end{array}$ & Rank & Ranking Rationale \\
\hline \multirow{17}{*}{$\begin{array}{l}\text { Reactor } \\
\text { Core } \\
\text { C7 }\end{array}$} & \multirow[t]{17}{*}{$\begin{array}{l}\text { Vertical } \\
\text { Channels }\end{array}$} & $\begin{array}{l}\text { Rod Worth and } \\
\text { Rod Pattem }\end{array}$ & P8 & $\mathbf{H}$ & $\begin{array}{l}\text { Control rods are withdrawn to raise } \\
\text { power }\end{array}$ \\
\hline & & 3D Kinetics & P9 & $\mathbf{H}$ & $\begin{array}{l}\text { High peaking at low power, possible } \\
\text { oscill. }\end{array}$ \\
\hline & & Void Feedback & $\mathbf{P} 10$ & $\mathbf{H}$ & $\begin{array}{l}\text { Possible voiding and its effect on } \\
\text { MCPR. }\end{array}$ \\
\hline & & $\begin{array}{l}\text { Doppler } \\
\text { Feedback }\end{array}$ & P11 & $\mathbf{H}$ & $\begin{array}{l}\text { The main feedback compensating rod } \\
\text { worth for criticality }\end{array}$ \\
\hline & & $\begin{array}{l}\text { Moderator } \\
\text { Feedback }\end{array}$ & P12 & $\mathbf{L}$ & $\begin{array}{l}\text { Moderator temperature feedback helps } \\
\text { compensating the rod worth for } \\
\text { criticality }\end{array}$ \\
\hline & & $\begin{array}{l}\text { Structure } \\
\text { Stored Energy, } \\
\text { Channel Boxes } \\
\end{array}$ & $\mathbf{P 2}$ & L & $\begin{array}{l}\text { Because of oscillations these behave } \\
\text { like temporary storages of heat. The } \\
\text { heat capacity is lower than fluid. }\end{array}$ \\
\hline & & $\begin{array}{l}\text { Fuel Stored } \\
\text { Energy }\end{array}$ & $\mathrm{P} 2$ & $\mathrm{H}$ & $\begin{array}{l}\text { Because of oscillations these behave } \\
\text { like temporary storages of heat. } \\
\text { Temperature of the fuel is much } \\
\text { higher than the fluid }\end{array}$ \\
\hline & & $\begin{array}{l}\text { Flux } \\
\text { Depression }\end{array}$ & P13 & $\mathrm{L}$ & Fuel centerline temperature is low \\
\hline & & $\begin{array}{l}\text { Gap } \\
\text { Conductance }\end{array}$ & P14 & $\mathbf{M}$ & $\begin{array}{l}\text { Affects thermal time constant for } \\
\text { oscillation }\end{array}$ \\
\hline & & Heat Transfer & P15 & $\mathrm{H}$ & $\begin{array}{l}\text { Impacts fluid temperature and vapor } \\
\text { genaration rate }\end{array}$ \\
\hline & & $\begin{array}{l}\text { Post } \\
\text { CHF/Rewet }\end{array}$ & P16 & NA & NA, Temperature is too low \\
\hline & & $\begin{array}{l}\text { 1- } \phi \text { Pressure } \\
\text { Drop }\end{array}$ & P5 & $\mathbf{M}$ & $\begin{array}{l}\text { The controlling factor for core flow, } \\
\text { but stabilizing. }\end{array}$ \\
\hline & & $\begin{array}{l}2-\phi \text { Pressure } \\
\text { Drop }\end{array}$ & P17 & $\mathbf{M}$ & $\begin{array}{l}\text { Impacts core flow and stability, } \\
\text { destabilizing. }\end{array}$ \\
\hline & & $\begin{array}{l}\text { Subcooled } \\
\text { Boiling }\end{array}$ & P18 & $\mathrm{H}$ & Main mechanism for boiling \\
\hline & & Condensation & $\mathrm{P} 22$ & $\mathrm{NA}$ & Condensation due to subcooled core \\
\hline & & $\begin{array}{l}\text { Equilibrium } \\
\text { boiling }\end{array}$ & P19 & $\mathbf{M}$ & $\begin{array}{l}\text { Secondary mechanism for vapor } \\
\text { generation at vapor-liquid interface }\end{array}$ \\
\hline & & Flashing & P3 & L & $\begin{array}{l}\mathrm{dP} / \mathrm{dZ} \text { and } \mathrm{dP} / \mathrm{dt} \text { induced flashing, } \\
\text { found no effect in Dodeward plant. }\end{array}$ \\
\hline
\end{tabular}


Table F.2 Phase II: Subcooled Chimney $\left(\tau_{1} \leq t \leq \tau_{2}\right)$ (Cont'd)

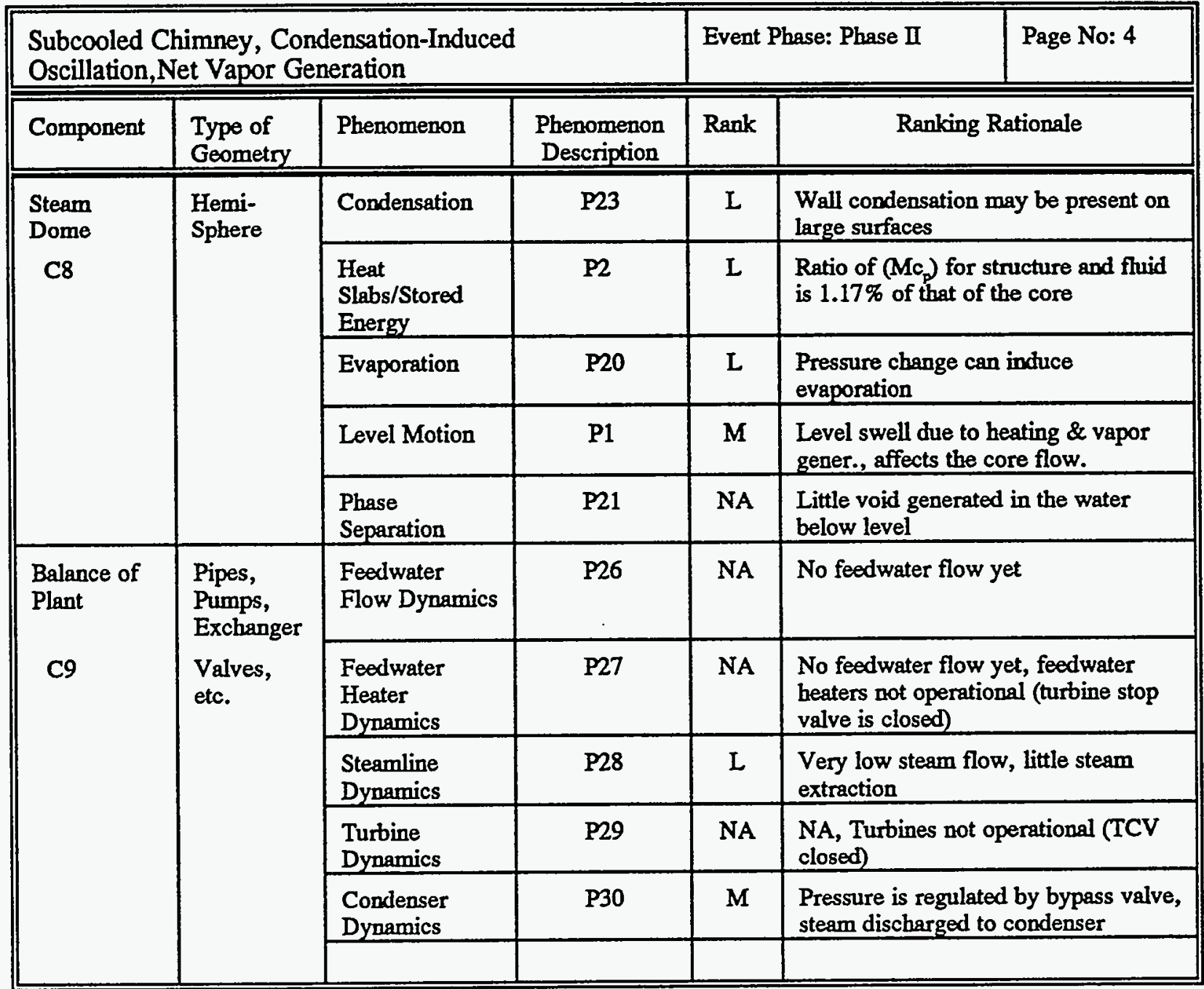


Table F.2 Phase II: Subcooled Chimney $\left(\tau_{1} \leq t \leq \tau_{2}\right)$ (Cont'd)

\begin{tabular}{|c|c|c|c|c|c|c|}
\hline \multicolumn{4}{|c|}{$\begin{array}{l}\text { Subcooled Chimney, Condensation-Induced Oscillation, } \\
\text { Net Vapor Generation }\end{array}$} & \multicolumn{2}{|c|}{ Event Phase: Phase II } & Page No: 5 \\
\hline Component & $\begin{array}{l}\text { Type of } \\
\text { Geometry }\end{array}$ & Phenomenon & $\begin{array}{l}\text { Phenomenon } \\
\text { Description }\end{array}$ & Rank & Ran & ationale \\
\hline \multirow[t]{3}{*}{$\begin{array}{l}\text { Control } \\
\text { Systems }\end{array}$} & \multirow[t]{3}{*}{$\begin{array}{l}\text { Wires, } \\
\text { Circuits }\end{array}$} & $\begin{array}{l}\text { Pressure } \\
\text { Regulator } \\
\text { Dynamics } \\
\end{array}$ & P31 & $\mathbf{M}$ & \multicolumn{2}{|c|}{$\begin{array}{l}\text { Pressure is controlled by bypass } \\
\text { valve. Possibility of resonance } \\
\text { feedback }\end{array}$} \\
\hline & & $\begin{array}{l}\text { Feedwater Control } \\
\text { System Dynamics }\end{array}$ & P32 & $\mathbf{N A}$ & \multicolumn{2}{|c|}{ No feedwater flow yet } \\
\hline & & $\begin{array}{l}\text { RWCU System } \\
\text { Level Control }\end{array}$ & P33 & $\mathbf{M}$ & \multicolumn{2}{|c|}{$\begin{array}{l}\text { RWCU is active for level control } \\
\text { and dictates subcooling }\end{array}$} \\
\hline
\end{tabular}


Table F.3 Phase III: Saturated Chimney $\left(\tau_{2} \leq t \leq \tau_{3}\right)$

\begin{tabular}{|c|c|c|c|c|c|c|}
\hline \multicolumn{4}{|c|}{ Saturated Chimney, Buoyancy-Driven Oscillations } & \multicolumn{2}{|c|}{ Event Phase: Phase II } & \multirow[t]{2}{*}{ Page No: 1} \\
\hline Component & $\begin{array}{l}\text { Type of } \\
\text { Geometry }\end{array}$ & Phenomenon & $\begin{array}{l}\text { Phenomenon } \\
\text { Description }\end{array}$ & Rank & Ranking Rationale & \\
\hline \multirow[t]{5}{*}{ Downcomer } & \multirow[t]{5}{*}{ Annulus } & Level Motion & P1 & NA & \multicolumn{2}{|c|}{$\begin{array}{l}\text { NA, Level not in downcomer (level } \\
\text { in dome) }\end{array}$} \\
\hline & & $\begin{array}{l}\text { Heat Slabs/Stored } \\
\text { Energy }\end{array}$ & $\mathbf{P} 2$ & L & \multicolumn{2}{|c|}{$\begin{array}{l}\text { Ratio of }\left(\mathrm{Mc}_{\mathrm{c}}\right) \text { for structure and } \\
\text { fluid is } 2.59 \% \text { of that of the core. }\end{array}$} \\
\hline & & Flashing & P3 & $\mathbf{M}$ & \multicolumn{2}{|c|}{$\begin{array}{l}\text { Important during potential } \\
\text { oscillations in the region above } \\
\text { feedwater entrance }\end{array}$} \\
\hline & & $\begin{array}{l}\text { Feedwater } \\
\text { Injection }\end{array}$ & P4 & $\mathbf{H}$ & \multicolumn{2}{|c|}{ Dictates subcooling and reactivity } \\
\hline & & 1- $\phi$ Pressure Drop & P5 & $\mathbf{L}$ & \multicolumn{2}{|c|}{$\begin{array}{l}\text { Small form loss in downcomer } \\
\text { (Provide number) }\end{array}$} \\
\hline \multirow{4}{*}{$\begin{array}{c}\text { Lower } \\
\text { Plenum } \\
\text { C2 }\end{array}$} & \multirow{4}{*}{$\begin{array}{l}\text { Pipe, } \\
\text { Structure } \\
\text { Horizontal } \\
\text { Vertical }\end{array}$} & $\begin{array}{l}\text { Heat Slabs/Stored } \\
\text { Energy }\end{array}$ & $\mathbf{P} 2$ & L & \multicolumn{2}{|c|}{$\begin{array}{l}\text { Ratio of }\left(\mathrm{Mc}_{\mathrm{p}}\right) \text { for structure and } \\
\text { fluid is } 2.59 \% \text { of that of the core. }\end{array}$} \\
\hline & & $\begin{array}{l}\text { CRD Flow } \\
\text { Injection }\end{array}$ & P6 & $\mathbf{L}$ & \multicolumn{2}{|c|}{$\begin{array}{l}\text { CRD flow is very low compared to } \\
\text { the core flow }\end{array}$} \\
\hline & & Flashing & P3 & $\mathrm{L}$ & \multicolumn{2}{|c|}{$\begin{array}{l}\text { Subcooled fluid may flash during } \\
\text { oscillations }\end{array}$} \\
\hline & & 1- $\phi$ Pressure Drop & P5 & $\mathbf{L}$ & \multicolumn{2}{|c|}{$\begin{array}{l}\text { Pressure drop is smaller than core } \\
\text { and riser pressure drops }\end{array}$} \\
\hline \multirow{2}{*}{$\begin{array}{l}\text { Guide Tube } \\
\text { C3 }\end{array}$} & \multirow[t]{2}{*}{ Pipe } & Flashing & P3 & NA & \multicolumn{2}{|c|}{ NA, Little pressure change } \\
\hline & & $\begin{array}{l}\text { Flow } \\
\text { Leakage/Refill }\end{array}$ & P7 & $\mathrm{L}$ & \multicolumn{2}{|c|}{$\begin{array}{l}\text { Contributes to bypass flow, less } \\
\text { important because of high core } \\
\text { flow }\end{array}$} \\
\hline
\end{tabular}


Table F.3 Phase III: Saturated Chimney $\left(\tau_{2} \leq t \leq \tau_{3}\right)$ (Cont'd)

\begin{tabular}{|c|c|c|c|c|c|c|}
\hline \multicolumn{4}{|c|}{ Saturated Chimney, Buoyancy-Driven Oscillations } & \multicolumn{2}{|c|}{ Event Phase: Phase III } & Page No: 2 \\
\hline Component & $\begin{array}{l}\text { Type of } \\
\text { Geometry }\end{array}$ & Phenomenon & $\begin{array}{l}\text { Phenomenon } \\
\text { Description }\end{array}$ & Rank & \multicolumn{2}{|c|}{ Ranking Rationale } \\
\hline \multirow[t]{2}{*}{ Core Bypass } & \multirow[t]{4}{*}{$\begin{array}{l}\text { Vertical } \\
\text { Channel }\end{array}$} & $\begin{array}{l}\text { Heat Slabs/Stored } \\
\text { Energy }\end{array}$ & $\mathbf{P 2}$ & $\mathbf{M}$ & \multicolumn{2}{|c|}{$\begin{array}{l}\text { Ratio of mass of structure is } 75 \% \\
\text { of the core. Ratio of flow is } 18 \% \\
\text { of the core. Temperature of } \\
\text { structure is high }\end{array}$} \\
\hline & & Flashing & P3 & $\mathrm{L}$ & \multicolumn{2}{|c|}{ Small $\mathrm{dP} / \mathrm{dz}$ and $\mathrm{dP} / \mathrm{dt}$} \\
\hline \multirow[t]{2}{*}{$\mathrm{C} 4$} & & 1- $\phi$ Pressure Drop & P5 & $\mathbf{M}$ & \multicolumn{2}{|c|}{$\begin{array}{l}\text { Determines the flow split between } \\
\text { core and bypass }\end{array}$} \\
\hline & & $\begin{array}{l}\text { Heat Transfer To } \\
\text { Bypass Channel }\end{array}$ & P15 & $\mathrm{L}$ & \multicolumn{2}{|c|}{ Less than $3 \%$ of reactor power } \\
\hline \multirow{4}{*}{$\begin{array}{l}\text { Chimney } \\
\text { and Upper } \\
\text { Plenum } \\
\text { C5 }\end{array}$} & \multirow[t]{4}{*}{$\begin{array}{l}\text { Pipe, } \\
\text { Structure }\end{array}$} & Phase Separation & P20 & $\mathrm{H}$ & \multicolumn{2}{|c|}{ Controls flow via buoyancy } \\
\hline & & $\begin{array}{l}\text { Flow Circulation } \\
\text { and Distribution }\end{array}$ & $\mathrm{P} 21$ & $\mathrm{~L}$ & \multicolumn{2}{|c|}{$\begin{array}{l}\text { It is only important for geysering, } \\
\text { there is } \\
\text { no geysering in this phase. }\end{array}$} \\
\hline & & Flashing & P3 & $\mathrm{H}$ & \multicolumn{2}{|c|}{$\begin{array}{l}\text { Chimney fluid is saturated and } \\
\text { flashing will take place. }\end{array}$} \\
\hline & & Level Motion & P1 & NA & \multicolumn{2}{|c|}{ No level in chimney. } \\
\hline \multirow{5}{*}{$\begin{array}{l}\text { Separator } \\
\text { and Dryer } \\
\text { C6 }\end{array}$} & \multirow{5}{*}{$\begin{array}{l}\text { Swirl } \\
\text { Vanes } \\
\text { Pipes }\end{array}$} & Pressure Drop & P17 & $\mathbf{M}$ & \multicolumn{2}{|c|}{ Impacts flow and oscillations } \\
\hline & & Separator Inertia & $\mathbf{P 2 3}$ & $\mathrm{H}$ & \multicolumn{2}{|c|}{ Large impedance to oscillations } \\
\hline & & Carryunder & $\mathrm{P} 24$ & $\mathbf{L}$ & \multicolumn{2}{|c|}{ Little carryunder } \\
\hline & & Carryover & $\mathrm{P} 25$ & L & \multicolumn{2}{|l|}{ Little carryover } \\
\hline & & Level Motion & P1 & NA & \multicolumn{2}{|c|}{ Level in steam dome } \\
\hline
\end{tabular}


Table F.3 Phase II: Saturated Chimney ( $\left.\tau_{2} \leq t \leq \tau_{3}\right)$ (Cont'd)

\begin{tabular}{|c|c|c|c|c|c|c|}
\hline \multicolumn{4}{|c|}{ Saturated Chimney, Buoyancy-Driven Oscillations } & \multicolumn{2}{|c|}{ Event Phase: Phase III } & Page No: 3 \\
\hline Component & $\begin{array}{l}\text { Type of } \\
\text { Geometry }\end{array}$ & Phenomenon & $\begin{array}{l}\text { Phenomenon } \\
\text { Description }\end{array}$ & Rank & \multicolumn{2}{|c|}{ Ranking Rationale } \\
\hline \multirow{17}{*}{$\begin{array}{l}\text { Reactor } \\
\text { Core } \\
\text { C7 }\end{array}$} & \multirow[t]{17}{*}{$\begin{array}{l}\text { Vertical } \\
\text { Channels }\end{array}$} & $\begin{array}{l}\text { Rod Worth and } \\
\text { Rod Pattern }\end{array}$ & P8 & $\mathbf{H}$ & \multicolumn{2}{|c|}{$\begin{array}{l}\text { Control rods are withdrawn to raise } \\
\text { power and maintain criticality }\end{array}$} \\
\hline & & 3D Kinetics & P9 & $\mathrm{H}$ & \multicolumn{2}{|c|}{$\begin{array}{l}\text { Power peaking is high at moderate } \\
\text { power level }\end{array}$} \\
\hline & & Void Feedback & P10 & $\mathrm{H}$ & \multicolumn{2}{|c|}{$\begin{array}{l}\text { Dominant feedback because of high } \\
\text { void }\end{array}$} \\
\hline & & Doppler Feedback & P11 & $\mathbf{M}$ & \multicolumn{2}{|c|}{$\begin{array}{l}\text { Helps void feedback to counter rod } \\
\text { worth for criticality }\end{array}$} \\
\hline & & $\begin{array}{l}\text { Moderator } \\
\text { Feedback }\end{array}$ & P12 & $\mathbf{L}$ & \multicolumn{2}{|c|}{$\begin{array}{l}\text { Helps void feedback to counter rod } \\
\text { worth for criticality. However, the } \\
\text { coolant is at saturation temperature } \\
\text { Temp change is small. }\end{array}$} \\
\hline & & $\begin{array}{l}\text { Structure Stored } \\
\text { Energy }\end{array}$ & P2 & L & \multicolumn{2}{|c|}{$\begin{array}{l}\text { Because of oscillations these } \\
\text { behave like temporary storages of } \\
\text { heat. }\end{array}$} \\
\hline & & $\begin{array}{l}\text { Fuel Stored } \\
\text { Energy }\end{array}$ & $\mathrm{P} 2$ & $\mathrm{H}$ & \multicolumn{2}{|c|}{$\begin{array}{l}\text { Because of oscillations these } \\
\text { behave like temporary storages of } \\
\text { heat. Temperature of the fuel is } \\
\text { significantly higher than the fluid }\end{array}$} \\
\hline & & Flux Depression & P13 & $\underline{L}$ & \multicolumn{2}{|c|}{ Affects fuel centerline temperature } \\
\hline & & Gap Conductance & P14 & $\mathrm{H}$ & \multicolumn{2}{|c|}{$\begin{array}{l}\text { Impacts fuel time constant and } \\
\text { important during oscillations }\end{array}$} \\
\hline & & Heat Transfer & P15 & $\mathrm{H}$ & \multicolumn{2}{|c|}{$\begin{array}{l}\text { Impacts fluid temperature and void } \\
\text { content }\end{array}$} \\
\hline & & Post CHF/Rewet & P16 & NA & \multicolumn{2}{|c|}{$\begin{array}{l}\text { NA, Temperature not high enough } \\
\text { yet }\end{array}$} \\
\hline & & 1- $\phi$ Pressure Drop & P5 & $\mathbf{M}$ & \multicolumn{2}{|c|}{ Impacts core flow and stability } \\
\hline & & 2- $\phi$ Pressure Drop & $\mathrm{P} 17$ & $\mathbf{M}$ & \multicolumn{2}{|c|}{ Impacts core flow and stability } \\
\hline & & $\begin{array}{l}\text { Subcooled Boiling } \\
\text { /Evaporation }\end{array}$ & P18 & $\mathrm{H}$ & \multicolumn{2}{|c|}{$\begin{array}{l}\text { Impacts vapor generation and } \\
\text { oscillations }\end{array}$} \\
\hline & & Condensation & $\mathbf{P 2 2}$ & $\mathbf{L}$ & \multicolumn{2}{|c|}{ Can occur during oscillations } \\
\hline & & Flashing & P3 & $\mathrm{L}$ & \multicolumn{2}{|c|}{$\begin{array}{l}\mathrm{dP} / \mathrm{dz} \text { and } \mathrm{dP} / \mathrm{dt} \text { induced } \\
\text { oscillations }\end{array}$} \\
\hline & & Fluid Inertia & & $\mathrm{H}$ & \multicolumn{2}{|c|}{ Controls the oscillations } \\
\hline
\end{tabular}


Table F.3 Phase MI: Saturated Chimney $\left(\tau_{2} \leq t \leq \tau_{3}\right)$ (Cont'd)

\begin{tabular}{|c|c|c|c|c|c|c|}
\hline \multicolumn{4}{|c|}{ Saturated Chimney, Buoyancy-Driven Oscillations } & \multicolumn{2}{|c|}{ Event Phase: Phase III } & \multirow[t]{2}{*}{ Page No: 4} \\
\hline Component & $\begin{array}{l}\text { Type of } \\
\text { Geometry }\end{array}$ & Phenomenon & $\begin{array}{c}\text { Phenomenon } \\
\text { Description }\end{array}$ & Rank & Ranking Rationale & \\
\hline \multirow{5}{*}{$\begin{array}{c}\text { Steam } \\
\text { Dome } \\
\text { C8 }\end{array}$} & \multirow[t]{5}{*}{$\begin{array}{l}\text { Hemi- } \\
\text { Sphere }\end{array}$} & Condensation & $\mathrm{P} 23$ & M & \multicolumn{2}{|c|}{$\begin{array}{l}\text { Large surface area for } \\
\text { condensation }\end{array}$} \\
\hline & & $\begin{array}{l}\text { Heat Slabs/Stored } \\
\text { Energy }\end{array}$ & P2 & $\mathbf{L}$ & \multicolumn{2}{|c|}{$\begin{array}{l}\text { Ratio of }(\mathrm{Mc}) \text { for structure and } \\
\text { fluid is } 1.17 \% \text { of that of the core. } \\
\text { Important during oscillation }\end{array}$} \\
\hline & & Evaporation & $\mathbf{P} 20$ & $\mathbf{M}$ & \multicolumn{2}{|c|}{$\begin{array}{l}\text { Súrface evaporation due to pressure } \\
\text { change }\end{array}$} \\
\hline & & Level Motion & P1 & $\mathrm{H}$ & \multicolumn{2}{|c|}{$\begin{array}{l}\text { Level swell due to heating and } \\
\text { vapor generation. Level affects the } \\
\text { natural circulation flow through } \\
\text { buoyancy. }\end{array}$} \\
\hline & & Phase Separation & $\mathbf{P} 21$ & L & \multicolumn{2}{|c|}{$\begin{array}{l}\text { Small amount of bubbles in level } \\
\text { cell }\end{array}$} \\
\hline $\begin{array}{l}\text { Balance of } \\
\text { Plant }\end{array}$ & $\begin{array}{l}\text { Pipes, } \\
\text { Pumps, } \\
\text { Exchanger }\end{array}$ & $\begin{array}{l}\text { Feedwater Flow } \\
\text { Dynamics }\end{array}$ & P26 & $\mathrm{H}$ & \multicolumn{2}{|c|}{$\begin{array}{l}\text { Feedwater syatem is operational to } \\
\text { control liquid inventory }\end{array}$} \\
\hline \multirow[t]{5}{*}{$\mathrm{C} 9$} & $\begin{array}{l}\text { Valves, } \\
\text { etc. }\end{array}$ & $\begin{array}{l}\text { Feedwater Heater } \\
\text { Dynamics }\end{array}$ & P27 & & \multicolumn{2}{|c|}{$\begin{array}{l}\text { NA, No feedwater heater in } \\
\text { operation }\end{array}$} \\
\hline & & $\begin{array}{l}\text { Steamline } \\
\text { Dynamics } \\
\end{array}$ & P28 & $\mathrm{L}$ & \multicolumn{2}{|c|}{$\begin{array}{l}\text { Active with low steam flow } \\
\text { because of low power }\end{array}$} \\
\hline & & Turbine Dynamics & P29 & NA & \multicolumn{2}{|c|}{$\begin{array}{l}\text { NA, Since turbine control valve is } \\
\text { still closed }\end{array}$} \\
\hline & & $\begin{array}{l}\text { Condenser } \\
\text { Dynamics } \\
\end{array}$ & P30 & $\mathrm{L}$ & \multicolumn{2}{|c|}{$\begin{array}{l}\text { System pressure will reach up to } 25 \\
\text { bar therefore steam line will open. } \\
\text { Bypass flow will become choked. }\end{array}$} \\
\hline & & & & & & \\
\hline
\end{tabular}


Table F.3 Phase III: Saturated Chimney $\left(\tau, s t \leq \tau_{3}\right)$ (Cont'd)

\begin{tabular}{||l|l|l|c|c|c||}
\hline \hline \multicolumn{2}{||}{ Saturated Chimney, Buoyancy-Driven Oscillations } & \multicolumn{2}{|l||}{ Event Phase: Phase III } & Page No: 5 \\
\hline Component & $\begin{array}{l}\text { Type of } \\
\text { Geometry }\end{array}$ & Phenomenon & $\begin{array}{l}\text { Phenomenon } \\
\text { Description }\end{array}$ & Rank & Ranking Rationale \\
\hline \hline $\begin{array}{l}\text { Control } \\
\text { Systems }\end{array}$ & $\begin{array}{l}\text { Wires, } \\
\text { Circuits }\end{array}$ & $\begin{array}{l}\text { Pressure } \\
\text { Regulator } \\
\text { Dynamics }\end{array}$ & P31 & M & Potential for resonance feedback \\
\cline { 2 - 6 } & $\begin{array}{l}\text { Feedwater Control } \\
\text { System Dynamics }\end{array}$ & P32 & H & $\begin{array}{l}\text { Starts to take over flow and level } \\
\text { control }\end{array}$ \\
\cline { 2 - 7 } & $\begin{array}{l}\text { RWCU System } \\
\text { Level Control }\end{array}$ & P33 & L & $\begin{array}{l}\text { Less important because of the } \\
\text { availability of the feedwater }\end{array}$ \\
\hline & & & & \\
\hline
\end{tabular}


Table F.4 Phase IV: Power Ascension to Operating Condition $\left(\tau_{3} \leq t \leq \tau_{3}\right)$

\begin{tabular}{|c|c|c|c|c|c|c|}
\hline \multicolumn{4}{|c|}{$\begin{array}{l}\text { Bulk Boiling, Density Wave Oscillations, Bigh Power, } \\
\text { Flow and Pressure }\end{array}$} & \multicolumn{2}{|c|}{ Event Phase: Phase IV } & Page No: 1 \\
\hline Component & $\begin{array}{l}\text { Type of } \\
\text { Geometry }\end{array}$ & Phenomenon & $\begin{array}{l}\text { Phenomenon } \\
\text { Description }\end{array}$ & Rank & \multicolumn{2}{|c|}{ Ranking Rationale } \\
\hline \multirow[t]{5}{*}{ Downcomer } & \multirow[t]{5}{*}{ Annulus } & Lovel Motion & P1 & NA & \multicolumn{2}{|c|}{$\begin{array}{l}\text { NA, Level not in downcomer } \\
\text { (level in dome) }\end{array}$} \\
\hline & & $\begin{array}{l}\text { Heat Slabs/Stored } \\
\text { Energy }\end{array}$ & P2 & L & \multicolumn{2}{|c|}{$\begin{array}{l}\text { Ratio of }\left(\mathrm{Mc}_{\mathrm{p}}\right) \text { for structure and } \\
\text { fluid is } 2.59 \% \text { of that of the core. }\end{array}$} \\
\hline & & Flashing & P3 & $\mathbf{M}$ & \multicolumn{2}{|c|}{$\begin{array}{l}\text { Flashing due to oscillation can } \\
\text { lead to change in core inlet flow }\end{array}$} \\
\hline & & $\begin{array}{l}\text { Feedwater } \\
\text { Injection }\end{array}$ & P4 & $\mathrm{H}$ & \multicolumn{2}{|c|}{$\begin{array}{l}\text { Main source of fluid which } \\
\text { impacts core flow and subcooling }\end{array}$} \\
\hline & & 1- $\phi$ Pressure Drop & P5 & $\mathbf{L}$ & \multicolumn{2}{|c|}{$\begin{array}{l}\text { Form losses in downcomer are } \\
\text { low }\end{array}$} \\
\hline $\begin{array}{l}\text { Lower } \\
\text { Plemum }\end{array}$ & $\begin{array}{l}\text { Pipe, } \\
\text { Structure } \\
\text { Horizontal }\end{array}$ & $\begin{array}{l}\text { Heat Slabs/Stored } \\
\text { Energy }\end{array}$ & $\mathrm{P} 2$ & $\mathrm{~L}$ & \multicolumn{2}{|c|}{$\begin{array}{l}\text { Ratio of }\left(\mathrm{Mc}_{\mathrm{p}}\right) \text { for structure and } \\
\text { fluid is } 2.8 \% \text { of that of the core. }\end{array}$} \\
\hline \multirow[t]{3}{*}{$\mathrm{C} 2$} & \multirow[t]{3}{*}{ Vertical } & $\begin{array}{l}\text { CRD Flow } \\
\text { Injection }\end{array}$ & P6 & L & \multicolumn{2}{|c|}{$\begin{array}{l}\text { CRD flow very small compared } \\
\text { to the core flow }\end{array}$} \\
\hline & & Flashing & P3 & L & \multicolumn{2}{|c|}{$\begin{array}{l}\text { Subcooled fluid may flash during } \\
\text { oscillations }\end{array}$} \\
\hline & & 1- $\phi$ Pressure Drop & P5 & L & \multicolumn{2}{|c|}{$\begin{array}{l}\text { Pressure drop small compared to } \\
\text { core and chimney pressure drop }\end{array}$} \\
\hline \multirow{3}{*}{$\begin{array}{l}\text { Guide Tube } \\
\text { C3 }\end{array}$} & \multirow[t]{3}{*}{ Pipe } & Flashing & P3 & NA & \multicolumn{2}{|c|}{ NA, Pressure change is small } \\
\hline & & $\begin{array}{l}\text { Flow } \\
\text { Leakage/Refill }\end{array}$ & P7 & L & \multicolumn{2}{|c|}{$\begin{array}{l}\text { Contributes to bypass flow, less } \\
\text { important because of high core } \\
\text { flow }\end{array}$} \\
\hline & & & & & & \\
\hline
\end{tabular}


Tahle F.4 Phase IV: Power Ascension to Operating Condition ( $\left.\tau_{3} \leq t \leq \tau_{4}\right)$ (Cont'd)

\begin{tabular}{|c|c|c|c|c|c|c|}
\hline \multicolumn{4}{|c|}{$\begin{array}{l}\text { Bulk Boiling, Density Wave Oscillations, High Power } \\
\text { Flow and Pressure }\end{array}$} & \multicolumn{2}{|c|}{ Event Phase: Phase IV } & \multirow{2}{*}{ Page No: 2} \\
\hline Component & $\begin{array}{l}\text { Type of } \\
\text { Geometry }\end{array}$ & Phenomenon & $\begin{array}{c}\text { Phenomenon } \\
\text { Description }\end{array}$ & Rank & Rankin & \\
\hline \multirow[t]{4}{*}{ Core Bypass } & \multirow[t]{4}{*}{$\begin{array}{l}\text { Vertical } \\
\text { Channel }\end{array}$} & $\begin{array}{l}\text { Heat Slabs/Stored } \\
\text { Energy }\end{array}$ & $\mathrm{P} 2$ & $\mathbf{M}$ & \multicolumn{2}{|c|}{$\begin{array}{l}\text { Ratio of mass of structure is } 75 \% \\
\text { of the core. Ratio of flow is } 18 \% \\
\text { of the core. Temperature of } \\
\text { structure is high }\end{array}$} \\
\hline & & Flashing & P3 & $\mathrm{L}$ & \multicolumn{2}{|c|}{ Less important than direct heating } \\
\hline & & 1- $\phi$ Pressure Drop & P5 & M & \multicolumn{2}{|c|}{$\begin{array}{l}\text { Determines the flow split between } \\
\text { channels }\end{array}$} \\
\hline & & $\begin{array}{l}\text { Heat Transfer To } \\
\text { Bypass Channel }\end{array}$ & P15 & L & \multicolumn{2}{|c|}{ Less than $5 \%$ of reactor power } \\
\hline \multirow{4}{*}{$\begin{array}{l}\text { Chimney and } \\
\text { Upper } \\
\text { Plenum } \\
\text { C5 }\end{array}$} & \multirow[t]{4}{*}{$\begin{array}{l}\text { Pipe, } \\
\text { Structure }\end{array}$} & Phase Separation & $\mathrm{P} 20$ & $\mathrm{H}$ & \multicolumn{2}{|c|}{$\begin{array}{l}\text { Controls flow and buoyancy due } \\
\text { to significant relative velocity } \\
\text { between liquid and vapor }\end{array}$} \\
\hline & & $\begin{array}{l}\text { Flow Circulation } \\
\text { and Distribution }\end{array}$ & $\mathrm{P} 21$ & $\mathrm{~L}$ & \multicolumn{2}{|c|}{$\begin{array}{l}\text { It is only important for geysering, } \\
\text { there is } \\
\text { no geysering in this phase }\end{array}$} \\
\hline & & Phase Change & P22 & $\mathbf{M}$ & \multicolumn{2}{|c|}{$\begin{array}{l}\text { Most of the chimney is saturated } \\
\text { therefore flashing and } \\
\text { condensation can happen only } \\
\text { during oscillations }\end{array}$} \\
\hline & & Level Motion & $\mathrm{P} 1$ & NA & \multicolumn{2}{|c|}{ NA, Level is not in chimney } \\
\hline \multirow{5}{*}{$\begin{array}{l}\text { Separator } \\
\text { and Dryer } \\
\text { C6 }\end{array}$} & \multirow{5}{*}{$\begin{array}{l}\text { Swirl } \\
\text { Vanes } \\
\text { Pipes }\end{array}$} & Pressure Drop & P17 & $\mathrm{H}$ & \multicolumn{2}{|c|}{ Impacts flow and stability } \\
\hline & & Separator Inertia & $\mathrm{P} 23$ & $\mathrm{H}$ & \multicolumn{2}{|c|}{ Large impedance to oscillations } \\
\hline & & Carryunder & $\mathrm{P} 24$ & $\mathbf{M}$ & \multicolumn{2}{|c|}{$\begin{array}{l}\text { Carryunder affects subcooling at } \\
\text { core inlet. }\end{array}$} \\
\hline & & Carryover & $\mathrm{P} 25$ & $\mathrm{~L}$ & \multicolumn{2}{|c|}{ Little carryover } \\
\hline & & Level Motion & $\mathrm{P} 1$ & $\mathrm{NA}$ & \multicolumn{2}{|c|}{ NA, Level is not in chimney } \\
\hline
\end{tabular}


Table F.4 Phase IV: Power Ascension to Operating Condition ( $\left.\tau_{3} \leq t \leq \tau_{4}\right)$ (Cont'd)

\begin{tabular}{|c|c|c|c|c|c|c|}
\hline \multicolumn{4}{|c|}{$\begin{array}{l}\text { Bulk Boiling, Density Wave Oscillations, High Power, } \\
\text { Flow and Pressure }\end{array}$} & \multicolumn{2}{|c|}{ Event Phase: Phase IV } & \multirow{2}{*}{\begin{tabular}{|l} 
Page No: 3 \\
Rationale
\end{tabular}} \\
\hline Component & Type of & Phenomenon & Phenomenon & Rank & Ranking Rationale & \\
\hline \multirow{16}{*}{$\begin{array}{l}\text { Reactor } \\
\text { Core } \\
\text { C7 }\end{array}$} & \multirow[t]{16}{*}{$\begin{array}{l}\text { Vertical } \\
\text { Channels }\end{array}$} & $\begin{array}{l}\text { Rod Worth and } \\
\text { Rod Pattern }\end{array}$ & P8 & $\mathbf{H}$ & \multicolumn{2}{|c|}{$\begin{array}{l}\text { Control rods are withdrawn } \\
\text { to raise power and maintain }\end{array}$} \\
\hline & & 3D Kinetics & P9 & $\mathrm{H}$ & \multicolumn{2}{|c|}{$\begin{array}{l}\text { High Peaking due to Rod } \\
\text { Removal }\end{array}$} \\
\hline & & Void Feedback & P10 & $\mathbf{H}$ & \multicolumn{2}{|c|}{$\begin{array}{l}\text { Dominant feedback because } \\
\text { of high void fraction }\end{array}$} \\
\hline & & $\begin{array}{l}\text { Doppler } \\
\text { Feedback }\end{array}$ & P11 & $\mathrm{H}$ & \multicolumn{2}{|c|}{$\begin{array}{l}\text { Feedback to counter rod } \\
\text { worth for criticality, limiy the } \\
\text { peak power. }\end{array}$} \\
\hline & & $\begin{array}{l}\text { Moderator } \\
\text { Feedback }\end{array}$ & P12 & $\mathrm{L}$ & \multicolumn{2}{|c|}{$\begin{array}{l}\text { It is small compared to void } \\
\text { feedback }\end{array}$} \\
\hline & & $\begin{array}{l}\text { Structure } \\
\text { Stored Energy }\end{array}$ & $\mathbf{P 2}$ & $\mathrm{H}$ & \multicolumn{2}{|c|}{$\begin{array}{l}\text { Because of oscillations these } \\
\text { behave like temporary } \\
\text { storages of heat. Temperature } \\
\text { of the structure is high. }\end{array}$} \\
\hline & & $\begin{array}{l}\text { Fuel Stored } \\
\text { Energy }\end{array}$ & $\mathbf{P} 2$ & $\mathrm{H}$ & \multicolumn{2}{|c|}{$\begin{array}{l}\text { Because of oscillations these } \\
\text { behave like temporary } \\
\text { storages of heat. Temperature } \\
\text { of the fuel is significantly } \\
\text { higher than the fluid }\end{array}$} \\
\hline & & $\begin{array}{l}\text { Flux } \\
\text { Depression }\end{array}$ & P13 & $\mathrm{L}$ & \multicolumn{2}{|c|}{$\begin{array}{l}\text { Affects fuel centerline } \\
\text { temperature }\end{array}$} \\
\hline & & $\begin{array}{l}\text { Gap } \\
\text { Conductance }\end{array}$ & P14 & $\mathrm{H}$ & \multicolumn{2}{|c|}{$\begin{array}{l}\text { Impacts fuel time constant } \\
\text { and oscillations }\end{array}$} \\
\hline & & Heat Transfer & P15 & $\vec{H}$ & \multicolumn{2}{|c|}{$\begin{array}{l}\text { Impacts fluid temperature and } \\
\text { void content }\end{array}$} \\
\hline & & $\begin{array}{l}\text { Post } \\
\text { CHF/Rewet }\end{array}$ & P16 & $\mathrm{NA}$ & \multicolumn{2}{|c|}{$\begin{array}{l}\text { NA, Temperature not high } \\
\text { enough yet }\end{array}$} \\
\hline & & $\begin{array}{l}\text { 1- } \phi \text { Pressure } \\
\text { Drop }\end{array}$ & P5 & $\mathbf{H}$ & \multicolumn{2}{|c|}{$\begin{array}{l}\text { Impacts core flow and } \\
\text { stability }\end{array}$} \\
\hline & & $\begin{array}{l}2-\phi \text { Pressure } \\
\text { Drop }\end{array}$ & P17 & $\mathrm{H}$ & \multicolumn{2}{|c|}{$\begin{array}{l}\text { Impacts core flow and } \\
\text { stability }\end{array}$} \\
\hline & & $\begin{array}{l}\text { Subcooled } \\
\text { Boiling } \\
\text { /Evaporation/ } \\
\text { Boiling } \\
\text { Boundary } \\
\end{array}$ & P18 & $\mathrm{H}$ & \multicolumn{2}{|c|}{$\begin{array}{l}\text { Impacts vapor generation and } \\
\text { oscillations }\end{array}$} \\
\hline & & Condensation & $\mathrm{P} 22$ & NA & \multicolumn{2}{|c|}{$\begin{array}{l}\text { NA Saturated core therefore } \\
\text { likely to have condensation }\end{array}$} \\
\hline & & Flashing & P3 & L & \multicolumn{2}{|c|}{$\begin{array}{l}\text { Heating is more important } \\
\text { than flashing }\end{array}$} \\
\hline
\end{tabular}


Table F.4 Phase IV: Power Ascension to Operating Condition $\left(\tau_{3} \leq t \leq \tau_{4}\right)$ (Cont'd)

\begin{tabular}{|c|c|c|c|c|c|c|}
\hline \multicolumn{4}{|c|}{$\begin{array}{l}\text { Bulk Boiling, Density Wave Oscillations, High Power, } \\
\text { Flow and Pressure }\end{array}$} & \multicolumn{2}{|c|}{ Event Phase: Phase IV } & Page No: 4 \\
\hline Component & $\begin{array}{l}\text { Type of } \\
\text { Geometry }\end{array}$ & Phenomenon & $\begin{array}{c}\text { Phenomenon } \\
\text { Description }\end{array}$ & Rank & \multicolumn{2}{|c|}{ Ranking Rationale } \\
\hline \multirow[t]{5}{*}{ Steam Dome } & \multirow[t]{5}{*}{ Hemi-Sphere } & Condensation & P23 & M & \multicolumn{2}{|c|}{$\begin{array}{l}\text { Large surface area for } \\
\text { condensation }\end{array}$} \\
\hline & & $\begin{array}{l}\text { Heat } \\
\text { Slabs/Stored } \\
\text { Energy }\end{array}$ & $\mathbf{P} 2$ & I & \multicolumn{2}{|c|}{$\begin{array}{l}\text { Ratio of }\left(\mathrm{Mc}_{\mathrm{p}}\right) \text { for structure and } \\
\text { fluid is } 1.17 \% \text { of that of the } \\
\text { core. Important during } \\
\text { oscillation }\end{array}$} \\
\hline & & Evaporation & $\mathbf{P} 20$ & $\mathbf{M}$ & \multicolumn{2}{|c|}{$\begin{array}{l}\text { Surface evaporation due to } \\
\text { pressure change }\end{array}$} \\
\hline & & Level Motion & $\mathbf{P 1}$ & $\mathbf{M}$ & \multicolumn{2}{|c|}{$\begin{array}{l}\text { Level swell due to heating and } \\
\text { vapor generation. This affects } \\
\text { the core flow }\end{array}$} \\
\hline & & Phase Separation & $\mathbf{P} 21$ & L & \multicolumn{2}{|c|}{$\begin{array}{l}\text { Small amount of bubbles below } \\
\text { the level }\end{array}$} \\
\hline \multirow{5}{*}{$\begin{array}{l}\text { Balance of } \\
\text { Plant } \\
\text { C9 }\end{array}$} & \multirow{6}{*}{$\begin{array}{l}\text { Pipes, } \\
\text { Pumps, } \\
\text { Exchangers, } \\
\text { Valves, etc. }\end{array}$} & $\begin{array}{l}\text { Feedwater Flow } \\
\text { Dynamics }\end{array}$ & $\mathrm{P} 26$ & $\mathrm{H}$ & \multicolumn{2}{|c|}{$\begin{array}{l}\text { Feedwater syatem is operational } \\
\text { to control liquid inventory }\end{array}$} \\
\hline & & $\begin{array}{l}\text { Feedwater } \\
\text { Heater } \\
\text { Dynamics }\end{array}$ & P27 & $\mathbf{M}$ & \multicolumn{2}{|c|}{$\begin{array}{l}\text { Impacts inlet subcooling and } \\
\text { density-wave oscillations }\end{array}$} \\
\hline & & $\begin{array}{l}\text { Steamline } \\
\text { Dynamics }\end{array}$ & P28 & $\mathbf{M}$ & \multicolumn{2}{|c|}{$\begin{array}{l}\text { Potential for turbine trip due to } \\
\text { spurious signal }\end{array}$} \\
\hline & & $\begin{array}{l}\text { Turbine } \\
\text { Dynamics }\end{array}$ & P29 & $\mathbf{M}$ & \multicolumn{2}{|c|}{$\begin{array}{l}\text { Affect feedwater temperature } \\
\text { and flow }\end{array}$} \\
\hline & & $\begin{array}{l}\text { Condenser } \\
\text { Dynamics }\end{array}$ & P30 & M & \multicolumn{2}{|c|}{ Provide inventory for feedwater } \\
\hline & & & & & & \\
\hline
\end{tabular}


Table F.4 Phase IV: Power Ascension to Operating Condition ( $\tau_{3} \leq t \leq \tau_{1}$ ) (Cont'd)

\begin{tabular}{|c|c|c|c|c|c|c|}
\hline \multicolumn{4}{|c|}{$\begin{array}{l}\text { Bulk Boiling, Density Wave Oscillations, High Power, Flow and } \\
\text { Pressure }\end{array}$} & \multicolumn{2}{|c|}{ Event Phase: Phase IV } & Page No: 5 \\
\hline Component & $\begin{array}{l}\text { Type of } \\
\text { Geometry } \\
\end{array}$ & Phenomenon & $\begin{array}{c}\text { Phenomenon } \\
\text { Description } \\
\end{array}$ & Rank & \multicolumn{2}{|c|}{ Ranking Rationale } \\
\hline $\begin{array}{l}\text { Control } \\
\text { Systems }\end{array}$ & $\begin{array}{l}\text { Wires, } \\
\text { Circuits }\end{array}$ & $\begin{array}{l}\text { Pressure } \\
\text { Regulator } \\
\text { Dynamics } \\
\end{array}$ & P31 & $\mathbf{H}$ & \multicolumn{2}{|c|}{$\begin{array}{l}\text { Required to regulate system pressure. } \\
\text { May have resonance feedback }\end{array}$} \\
\hline \multirow[t]{3}{*}{$\mathrm{C} 10$} & & $\begin{array}{l}\text { Feedwater Control } \\
\text { System Dynamics }\end{array}$ & P32 & $\mathrm{H}$ & \multicolumn{2}{|c|}{$\begin{array}{l}\text { Control core flow and water level in } \\
\text { RPV. Can have resonance feedback }\end{array}$} \\
\hline & & $\begin{array}{l}\text { RWCU System } \\
\text { Level Control }\end{array}$ & P33 & NA & \multicolumn{2}{|c|}{$\begin{array}{l}\text { NA, Feed water flow is established } \\
\text { therefore RWCU is no longer } \\
\text { required }\end{array}$} \\
\hline & & & & & & \\
\hline
\end{tabular}


(See instructions on the reverse)

Preliminary Phenomena Identification and Ranking Tables (PIRT) for SBWR Startup Stability

3. DATE REPORT PUBLISHED

\begin{tabular}{c|c} 
MONTH & $\begin{array}{r}\text { YEAR } \\
\text { March }\end{array}$ \\
1997
\end{tabular}

4. FIN OR GRANT NUMBER

L2187

5. AUTHOR(S)

6. TYPE OF REPORT

U.S. Rohatgi, H.S. Cheng, H.J. Khan and W. Wulff

B, PERFORMING ORGANIZATION - NAME AND ADDRESS I/f NAC, provide Division, Office or Region, U.S. Nuelear Regulatory Commission, and mailing address, if contractor, provide name and mailling address.

Brookhaven National Laboratory

Upton, NY 11973

9. SPONSORING ORGANIZATION - NAME AND ADORESS IIf NRC, troe "Same as above"; if contractor, provide NRC Division, Otfice or Region. U.S. Nuclear Regulatory Commission. and malling address,

Division of Systems Technology

Office of Nuclear Regulatory Research

U.S. Nuclear Regulatory Commission

Washington, DC 20555-0001

10. SUPPLEMENTARY NOTES

11. ABSTRACT (200 words or less)

Phenomena Identification and Ranking Tables (PIRT) have been developed for start-up transient for SBWR. The information used for PIRT came from RAMONA-4B and TRACG analyses of the transient and from related small scale tests. The transient was divided into four distinct phases, namely, Sub-Cooled Core Heat-up, Subcooled Chimney, Saturated Chimney, and Power Ascension. The assessment criterion selected was Minimum Critical Power Ratio. The SBWR system was divided into ten components. A total of 35 distinct phenomena among the components were identified. The Phase I has 28 ranked phenomena with 17 low, 6 medium, and 5 high ranking. The Phase II has 39 ranked phenomena with 18 low, 13 medium and 8 high ranking. The Phase III has 47 ranked phenomena with 22 low, 10 medium and 15 high ranking. The Phase IV has 46 ranked phenomena with 16 low; 12 medium and 18 high ranking.

BWR Type Reactors - Mitigation,

BWR Type Reactors - Stability,

BWR Type Reactors - Transients,

Reactor Operation - Decision Making,

Transients - Reactor Start-up,

Accidents,

After Heat Removal, BNL, Calculation Methods, Computer Codes, Computerized Simulation, Convection, Heat Removal, Hydraulics, $\mathrm{R}$ Codes, Reactor Control Systems, T Codes, Testing.

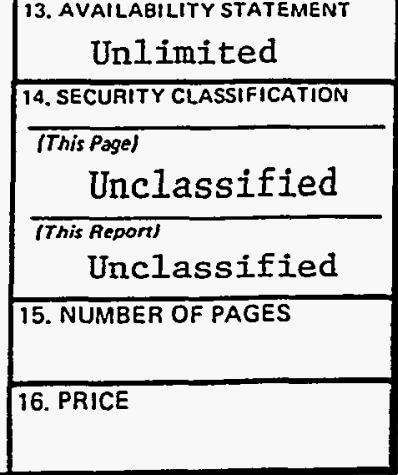

